
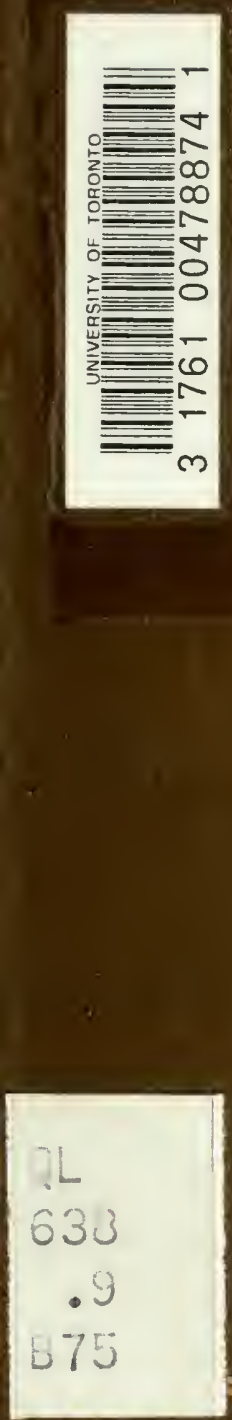

TORONTO LIBRARY 
Digitized by the Internet Archive in 2008 with funding from Microsoft Corporation 




\section{I S T}

OF TER

\section{SPECIMENS OF F ISH}

THE COLLECTION

OF THE

B R I T I S H M S E U M.

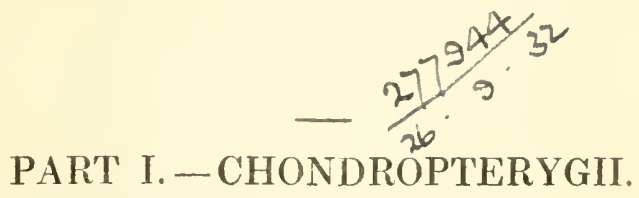

PRINTED BY ORDER OF THE TRUSTEES. LONDON, 1851. 


\section{LONDON :}

PRINTED BY EDWARD NEWMAN, 9, DEYONSHIRE ST., BISHOPSGATE.

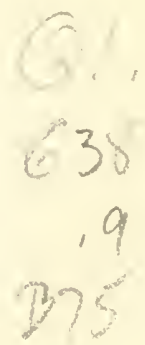




\section{INTRODUC'TION.}

The principal object of the prosent Catalogue has heen to give a complete list of the specinens of Fish contained in the collection of the British Inscum, indicating the peculiaritien of each, as regards variation of character, lucality, and the source from whence it has been iterivel.

The characters of the general of Sharks and Rays, with the syonyms, have principally been derived from the work of Professors Muller and Henle. The specimens which were not named by those Authors when engaged on their work. wr by Dr. Andrew Sinith, have heen determined by Mr. Filward Gerrard, who has paid considerable attention to this sulject, and has compared several of the specimens with the authentic typen contained in the Paris collection.

The more important characters of the new genera of Lannpreys are figured.

The other parts of this List will follow as soon as they ran be completed.

TOHN EDWARD GRAL.

British Museum, . July $25 t h .1851$. 



\section{SYSTEMATIC INDEX.}

1. Chondropterygit, p. 1, 151 14. A. Sturio, 13, 151

Sub-ord. 1. Eleutheropomi, 3, 15. A. latirostris, 15 151

Sect. A. Strriora, 3

Fam. 1. Aclpexserid.e, 4

1. Acipenser, 4

* Lioniscus, 4

1. A. glaber, 6

** Acipenser, 6

2. A. chinensis, 6

3. A. Gmelini, 7

4. A. Ruthenus, 7

5. A. Aleutensis, 8

6. A. maculosus, 8

7. A. oxyrliynchus, 8

8. A. rupertianus, 9

9. A. transmontanus, 9

9.*A. carbonarius, 9,151

*** Helops, 9

10. A. stellatus, 9

**** Antaceus, 11

11. A. Schypa, 11

12. A. Guldenstadtii, 11

***** Sturio, 12

13. A. Heckelii, 12

****** Huso, 15

16. A. brevirostris, 15

17. A. rubicundus, 16

18. A. macrostomus, 16

19. A. Dauricus, 16

20. A. Ichthyocolla, 18

2. Scaphyrhynchus, 18 1. S. cataphractes, 18

3. Dinectes, 18

I. D. truncatus, 18

4. Proceros, 19

1. P. maculatus, 19

2. P, vittatus, 19

Fam. 2. Polyodontid.e, 19

1. Pulyodon, 19

1. P. spatula, 20

Sect. B. Chrueria, 20

Fam. 1. Chinærade, 21

1. ChIM⿸ra, 21

1. C. monstrosa, 21

2. C. Collici, 21

2. Callorhyschus, 22

1. C. autaretica, 22 
Sub-ord. II. Treshtopxe.1, 22 * Scoliodon, 41

Ord. III, Plagiostomia, 22, 151

1. S. laticaudus, 41

2. S. acutus, 41

3. S. Lalandii, 42

Sect. 1. Sovali, 24

Fam. 1. Scylliade, 27

1. Scyllium, 27

1. S. Edwardsii, 28

2. S. pictum, 28

3. S. maculatum, 28

4. S. caniculum, 2 y

5. S. catulus, 30

6. S. Burgeri, 30

7. S. bivium, 31

8. S. capense, 31

9. S. africanum, 31

10. S. pantherinum, 31

11. S. variegatum, 32

2. Pristinurus, 32

1. P. melanostomus, 32

3. HeMiscruliem, 33

1. H. ocellitum, 33

2. H. trispeculare, 33

4. Chuloscyllium, 34

1. C. plagiosum, 34

2. C. punctatum, 35

3. C. tubereulatum, 35

4. C. obscurum, 35

5. C. griseum, 35

6. C. malaianum, 35

5. Crossorinnus, 35

1. C. barbatus, 36

6. Nebrils, 36

1. N. concolor, 37

2. N. cirratum, 37, 151

7. Stegosto 1 a, 38

I. S. fasciatum, 38

Fam. 2. Squalide, 39

I. Squaliana, 40

1. Squalus, 41

* Triglochis, 42

4. S. Mulleri, 42

*** Aprion, 42

5. S. brevipinna, 42

6. S. acutidens, 43

7. S. isodon, 43

**** Hypoprion, 43

8. S. Macloti, 43

9. S. hemiodon, 43

***** Carcharinus, 43

10. S. glaucus, 44,152

11. S. caudata, 44

12. S. cæruleus, 44

13. S. Lamia, 44

14. S. Milberti, 45

15. S. Gangeticus, 45

16. S. glyphis, 45

17. S. amboineusis, 45

18. S. vxyrhynchus, 45

18* S. obrelatus, 152

19. S. leucas, 46,152

20. S. melauopterus, 46

21. S. albimarginatus, 46

22. S. Maou, 46

23. S. Sorrab, 47

24. S. obscurus, 47

25. S. Henlei, 47

26. S. Menisorrab, 47, 152

27. S. falciformis, 47

28. S. Dussumieri, 47

29. S. Temminckii, 48,152

30. S. limbatus, 48

2. Sirhyrias, 48.

1. S. Zygæna, 48

2. S. tudes, 50

3. S. tibura, 50

4. S. Blochii, 50

5. S. Mokarran, 51 
II. Leptochariana, 51

1. Leptocharias, 51

1. L. obesus, 51

2. L. Smithii, 51

III. Galeiana, 52

1. Galets, 52

1. G. canis, 52

2. G. Japanicus, 53

2. Galeocerdo, 53

1. G, tigriuns, 54

2. G. areticus, 54

3. Loxonox, 54

1. L. macrorhinus, 54

4. Thalassorhincs, 54

1. T. Rondeletii, 55

2. T. platyrlyuchus, 55

IV. Triakiana, 55

1. Triakis, 55

1. T. scyllium, 55

2. T. californica, 56

V. Musteliana, 56

1. Mesteles, 56

1. M. vulgaris, 56,152

1.* M. equestris, 152

2. M. læris, 57

3. M. punctulatus, 57

4. M. megalopter'us, 5s

VI. Isurina, 58

1. Isurus, 58

1. I. cornubicus, 58

2. Oxyrhixi, 59

1. O. goinphodon, 60

2. O. glanca, 60

3. O. punctata, 60

3. Carcharodon, 60

1. C. Roudeletii, 61

4. Cetorhines, 61

1. C. maximus, 61

VII. Odontaspidiana, 62

1. Odontaspis, 62
1. O. Taurus, 63

2. O. ferox, 63

VIII. Alopeciana, 63

1. Alopiss, 64

1. A. vulpes, 64

IX. Heterodontina, 65

2. Hriteionontus, 65

1. H. Zehra, 65

2. H. Philippi, 66

3. H. pantherinus, $66^{\circ}$

X. Rhineodontiana, $66^{\circ}$

1. Ruinodos, 66

1. R. typicus, 67

XI. Hexanchina, 67

1. Hexanches, 67

1. H. griseus, 67

2. Heptranches, 68

1. H. indicus, 68

2. H. cinereus, 69

XII. Acantiana, 69

1. Acamthias, 69

1. A. Blainvillii, 70

2. A. vulgaris, $7 \mathrm{l}$

3. A. lyatus, 71

2. SpINAX, il

1. S. niger, 71

3. Oxpnotes, 72

1. 0 . centrina, 72

4. Acanthorhines, 73

1. A. granulosus, 74

2. A. squamosus, 74

5. Cevtroscyllita, 74

1. C. Fabricii, 74

XIII. Dalatiana, 74

1. Dalatias, 75

a. Dalatias, 75

1. D. Lichia, 75

2. D). brasiliensis, 76

b. Sommiosus, 76

3. D. borealis, 76 
4. D. bispinatus, 77

5. D. rostratus, 77

2. Echixorhives, 77

1. E. spinosus, 78

Fam. 3. Soratixida, 78

1. Sugativa, 79

1. S. vulgaris, 79

1. ${ }^{* S}$. oculatit, 153

2. S. fimbriata, 80

3. S. Angelina, 80

Sect. II. RAI1, 81

Fam. 4. Pristisid.e, 87

1. Pristophoris, 87

1. P. cirratus, 88

2. Pristis, 88

1. P. antiquorum, 89

2. P. pectinatus, 90

3. P. microdon, 90

4. P. enspidatus, 90

5. P. semisagittatus, 91

6. P. Perotteti, 91

Fam. 5. RaID.E, 91

I. Rhince,9I

1. Rhixa, 92

1. R. ancyelostomus, 92

2. Rhynciobatus, 92

I. R. læyis, 92

II. Rhinobatina, 93

l. Rhixomates, 93

* Syrrhiza, 94

1. R. Columnæ, 94

2. R. brevirostris, 94

3. R. Blochii, 94

4. R. annulatus, 94

5. R. Bougainvillii, 95

6. R. Banksii, 9.5

* Rhinobatus, 95

7. R. uramulatus, 95

8. R. Halivi, 95

9. R. cemiculus, 96

10. li. Philippi, 96
11. R. armatus, 96

12. R. 'Tlonini, 96

13. R. undulatus, 96

14. R. obiusus, 97

15. R. Horkeli, 97

16. R. Schlegelii, 97

17. R. hymicephalus, 97

2. Trygoxormini, 97

1. T. fusciata, 98

3. Platrinisa, 95

I. P. sinensis, 98

2. P. Schonlenii, 9s

JI1. Torpedininu, 99

1. Tolzpeno, 99

1. 'T. venlata, 99

2. T. nobiliana, 100

3. T. mirmorata, 100,153

4. T. panthera, 101

5. T. trepidana, 153

2. Narclxe, 101

1. N. hrasiliensis, 102

2. N. indica, 102

3. N. lingula, 102

4. N. Timlei, $10^{\circ}$

5. N. Tasmaniensis, 102

2.*Discopyge, 153

1. D. Tschudii, $15: 3$

3. Astrape, 103

1. A. eapensis, 103

2. A. dipterygia, 103

4. Tenela, 103

1. T. Hardwickii, 104

IV. Raice, 104

1. RAJA, 104

1. R. radula, 105

2. R. atra, 105

3. R. undulata, 105

4. R. elavata, 106

5. R. rudliata, 107

6. R. navis, 107

7. R. Schultzii, 107 
8. R. asterias, 108

8.*R. bramante, 154

9. R. marginata, 108

10. R. miraletus, 108

11. R. microcellata, 109

12. R. Salviani, 109

13. R. vomer, 110

14. R. fullonica, 110

15. R. Batis, 110

16. R. intermedia, 111

17. R. lintea, 111

18. R. oxyrhynchus, 111

19. R. Kenojei, 112

20. R. nasuta, 112

21. R. maroccana, 112

22. R. Smithii, 112

23. R. capensis, 112

24. R. Lemprieri, 112

25. R. erinaceus, 112

26. R. americana, 112

27. R. diaphanes, 113

28. R. oculata, 113

29. R. brasiliensis, 113

2. Sympterygia, 113

1. S. Bonapartii, 113

3. Uraptera, 113

1. U. Agassizii, 113

V. Trigonina, 114

A. Urogymni, 114

1. Urogrinus, 114

1. U. Africanus, 115

2. U. asperrimus, 115

B. Pastinace, 115

I. Trygon, 115

1. T. Uarnak, 116

2. T. Gerrardi, 116

3. T. Walga, 117

4. T. purpurea, 117

5. T. Jabebara, 117

6. T. Aiereba, 117

7. T. Bennetti, 118

8. T. thalassia, 118
9. T. pastinaca, 118,154

10. T. Brucco, 119, 154

11. T. violacea, 119

12. T. Sabina, 119

13. T. imbricata, 119

14. T. Kuhlii, 120

15. T. Akajei, 120

16. T. Zugei, 120

17. T. Sayi, 120

18. T. hystrix, $3: 20$

19. T. strogylopterus, $1: 20$

20. T. garrapa, 120

21. T. hastata, 121

22. 'T. carnea, 121

2. Elipesurus, 121

1. E. spinicauda, 121

3. Daspatis, 121

I. D. altarela, 122

2. D. canarieusis, 12 2

3. D. micrura, 122

4. D. maclura, 123

4. Hrpolophus, 123

1. H. Sephen, 123

5. T⿸NIURA, 124

I. T. Iymma, 124

2. T. Meyeni, 124

3. T. Grabata, 125

4. T. motoro, 125

C. Urolophi, 125

1. Trygonobatus, 12.5

1. T. torpedinus, 125

2. T. aurantiacus, 126

3. T. armatus, 126

4. T. ephippiatus, 126

D. Trygonoptera, 126

1. Trygonoptera, 126

1. T. testacea, 126

2. Etoplatea, 127

1. E. tentaculata, 127

VI. Myliobatina, 127

1. Myliobatis, 127

1. M. aquila, 128 
2. M. Nieuhofii, 129

3. M. Milvus, 129

4. M. maculatus, 129

5. M. vultur, 129

6. M. oculeus, lig

7. M. episcopus, 129

2. Етов.тт1s, 130

I. E. Narinari, 130

2. Æ. flagellum, 130

3. Rinsoptera, 131

1. R. marginata, 131

2. R. Lalandii, 131

3. R. Mrasiliensis, 131

4. R. Javanica, 132

5. R. adspersat, 132

6. R. quadriloba, 132

7. R. Smithii, 132

III. Cephaloptera, 132

1. Cephiloptera, 133

1. C. Giorna, 133

2. C. Ollersii, 133

3. C. Ḱuhlii, 134

4. C. Japonica, 134

2. Ceratoltera, 134

1. C. Johnii, 134

2. C. Ehrenbergii, 134

Order Cyclostoma, 136

Fam. 1. Petromyzonide, 136

I. Petromyzonina, 137

1. Petromyzon, 137

1. P. marinus, 138

2. P. Juræ, 139

3. P. americanus, 139

4. P. nigricans, 139

5. $P$. argenteus, 139

2. LAMPETRA, 140

1. L. fluviatilis, 140

2. L. planeri, 141
3. L. Sanguisuga, 141

4. L. Lamoltenii, 142

3. Geotut, 142

1. G. anstralis, 142

4. Velasia, 143

1. V. clitensis, 143

5. Caragola, 143

1. C. latpicidal, 143

6. Mordacla, 1.13

1. M. mordax, 144

1. Petromyzon appendix, 144

2. P. tridentatus, 144

3. P. argenteus, 144

4. P. bicolor, 144

5. P. plumbeus, 145

II. Ammocatina, 145

7. Awnocetes, 145

1. A. branchialis, 145

2. A. ruber, 146

3. A. collcolor, 146

4. A. bicolor, 146

5. A. unicolor, 146

Fam. 2. Mrxinide, 147

I. MYXINE, 147

1. M. glutinosa, 147

2. Boellostomi, 148

1. B. hexatrema, 148

2. B. heterotrcma, 148

3. B. lieptatrema, 148

4. B. Forsterii, 149

5. B. Dombeyii, 149

Fim. 3. Anphioxide, 149

1. Branchiostona, $\mathbf{1 4 9}$

1. B. lubrieum, 150

2. B. lanceolatum, 150

3. B. Belcheri, 150 


\section{LIST OF FISH.}

\section{Order I. CHONDROP'TERYGII.}

Skeleton cartilagineous. Cranium without sutures. Pisces Chondropterygii, Gmel. Syst. Nat. 1131, 1483. Amphibia Nantes, part, Limn. Nyst. Nat. i. 349. 394. Chondropterygiens, Cux. Réq. Anim. 1817, ed. ii. 376, 1829. Pisces cartilaginei, Raii, Sym. Pist. 18, 1763.

Lampetræ, Raii, Sym. Pisc. 38.

Chondropterygia, Miill. Abh. Akad. Berl. 1836. Ma\%. Zool. s. Bot. i. 405.

Ichthyosia ateleosia, Eltropomia Pomachia, part, Rafin. Anal. Nat. $92,1815$.

Ichthyosia ateleosia, Chismopnea branchismea, part, Rafin. Anal. Nat. $92,1815$.

Ichthyosia ateleosia, Tremapnea plagiostomia and cyclostomia, part, Rafir. Anal. Nat.92, 1815.

Cartilagineous fislses, Gray, Syn. B. M., 1842, 147.

Chondrodia and Enchelares, part, Retzius, Anim. Piscium, 1803.

Rafinesque, in his 'Analyse de Nature,' 1815, Svo., divides the fish or Ichthyosia into those which liave complete (Holobranchia) and incomplete gills (Ateleosia), and he separates the cartilagineous fish in to three orders of that sub-class, viz.: v. Eltropomea, Aciperser. vi. Chismopomea, Chimæra. viii. Tremapnea, Squalus, Raia, and Petromyzon, \&c. 92, 1845. 
Joln Rity, in his 'Synnpsis Methodicus Piscium,' 1711, placed the cartilagineous fishes together in a group, and divided them into 1. Cartilaginei longi $=$ Squalus - 2. C. plani et lati $=$ Raia.3. The lampreys by themselves.

Liunæus (Syst. Nat. ed. 2, p. 349, 1766) arranged these animals with the Amphibia; forming lor them and some other anomalous tish, as Lophius, Cyclopterus, Dindon, d.c., an order desiguated Nantes. This order was divided into two divisions, as I. Spiracles compound, or many, as Petromyzzon, spiracles 7. Raja and SquaTus, spiracles 5. Chimara, spiracle single, four cut. II. Spiracles single, containing Acipenser and the other anomalous fishes.

Ginelin, (Syst. Nat. i. 1131), who adopted Artedi's arrangement, remored them and the other anomalous lish and formed them into an order, called Chrondropterygii.

M. De Blaiuville, in lis new distribution of the Animal Kingdom (Bull. Soc. Phil. 1816, 120, and Jour. de Phys. 1816, 260), forms the cartilagineous fish into a sub-class, which be calls Dermodontes ou Cartilagineux, and divides them into four orders: - 1. Cyclostomes -2. Selaques (Selaca).-3. Esturgeons.-4. Polydontes.

Cuvier, in his 'Règne Animal', ii. 1817, 2 ed. 278, 1829, arranges the cartilagineous fish thus:-1. A branchies libres. Fam. 1. Sturioniens.-1. Esturgeons. - 2. Polyodons. - 3. Chimeres (Chimeres and Callorhynques). - 2. A branchies fixes. Fam. 2. Selaciens. -1. Squalus. - 2. Marteaux. - 3. Auges. - 4. Scies. - 5. Raies. Fam. 3. Suceurs ou Cyclostomes, Règ. Anim. 2 ed. 278, 1829.

Professor John Mïller, in his 'Anatomy of Cyclostomata', in the Berlin Academy for 1836, proposes the following arrangement of the Chondropterygia:-Order 1. Brachiostega. Fam. 1. Cataphracta. a. Sturiones. - 1. Sturio. a. Huso sturio, sterlata, and Helops. Fam. 2. Nuda. b. Spathularix-2. Spathularia. Order 2. Holocephala. 1. Chimera.-2. Callorhynchus. Order 3. Plagiostomata. Fan. 1. Squali. 1. Squalus.-2. Zygæna.-3. Squalina.-4. Pristis. Fam.2. Raiaæ.-5. Rhinobates.-6. Torpedo. -7. Raia. - 8. Prolterygia. - 9. Myliobates. - 10. Ceplialoptera. Order 4. Cyclostomata. Fum. 1. Hyperoartia, a. Dentata.-1. Petromyzon. b. Edcntata.-2. Ammocœtes. Fam, 2. Hyperotreta. 3. Myxime.-4. Bodellostowa. 
Charles Buonaparte ('Systema Ichthyologium,' 1838, 4to.) divides the cartilaginous fish among three of his sub-classes, according to the form of the gills. Sub-class 1. Elasmobranchii. Section 1. Plagiostomi. Order 1. Selatha. Fam. 1. Raidæ.-2. Squalidæ. Order 2. Acanthorrini. Fam.3. Chimæridæ. Sub-class 3. Pomatobranchii. Section 2. Micrognathii. Order 6. Sturiones. Fam.8. Polydontidæ.-9. Acipenseridæ.

Professor John Müller, in his new arrangement of fishes (Weign. Arch. 134, 1845), divides the cartilaginons fish into three subclasses. III. Gamidea. Order 2. Chondrostei. Fam. 1. Acipenserini.-2. Spathulariæ. IV. Elasmobranchii seu Selachii. Order 1. Plagiostomi. Sub-order 1. Squalidæ. - 2. Rajidæ. Order 2. Holocephali. Fam. 1. Chimæræ. Sub-class 5. Marsipobanchii seu Cyclostomi. Order 1. Hyperoartii. Fam. 1. Petromyzonini. Order 2. Hyperotreti. Fam. 1. Myxinoidea. Sub-class 6. Leptocardii. Order 1. Amphioxini. Fam. 1. Amphioxini.

Mr. Gray, in the 'Synopsis of the British Musenm' for 1842, arranged them as follows:-1. Acipenseride. - 2. Chimarade. - 3. Squalida. - 4. Raida. - 5. Petromyzida.-6. Amphioxida, p. 147 and 150 .

\section{Sub-Order I. ELEUTHEROPOMI.}

Gills free.

Ch. a branchies libres, Cuv. Règ. Anim. ii. 2 ed. 27, 378.

Ch. Branchiostega and Ch. Holocephala, Mïll. Abh. Aliad. Berl. 1816.

Ch. Eleutheropoma, De Kay, Hist. New York.

Eltropomia pomachia, part, Rafin. Anal. Nat. 92, 1815.

Elasmobranchii aud Pomatobranchii, part, Bonap. Syst. Ichth. $1838,13$.

Ganoidia chondrostei, Müll. Weign. Arch. 134, 1848.

\section{Section A. STURIONA.}

Ch. Brachiostega, Miell. Abh. Akad. Berl. 1836. Mag. Zool. f Bot. i. 405.

Les Sturionievs ou chondropterygiens a branchies libres (part.), Cuv. Règ. Anim. 2 ed. ii. 378.

Sturiona, Rafin. Anal. Nat. 92, 1815.

Pomatobranchii Micrognathi, Bonap. Syst. Ichth. 1838, 13.

Sturioues, Bonap. Syst. Ichth. 1838, 13. 


\section{Fam. 1. ACIPENSERID E.}

Cartilage of cranium and skin of body corered, at intervals, with cartilagineous or bony shields.

Acıpenser, Linn. Syst. Nat.

Sturio, Liafin. Anal. Nat. 1810.

Les esturgeons, Cuv. Règ. Anim. 2 ed. ii. 378, 1829.

Brach. cataphracta seu Sturiones, Miill. Abh. Akad. Berl. 1836.

Sturiona, part, Rafin. Anal. Nat. 92.

Acipenseridæ (Acipenserini), Bonap. Syst. Ichth. 1838, 13.

Aoipenseridæ, Gray, Syn. B. M. 1840.

Acipenserivi, Miill. Weign. Arch. 134, 1845.

\section{ACIPENSER.}

Nose conical, tatpering. Head slielded. Mouth bencath the base of the muzzle, with four or six beards in front. Eyes and nostrils lateral. Body elongate, with longitudinal series of bony plates. Dorsal single behind the ventral and over the aual. The tail-fin produced with a short under lobe.

Rafinesque (Ichthyologia Ohiensis, 79, 1820) proposed to divide this genus into two, thus: -1 . Sturio, with five. 2. Sierletus, with three rows of bony plates.

Professor Brandt (in Brandt f. Ratz. Med. Zool, ii. 1830, 4to.) at first divided the sturgeons as follows :-

1. IIuso.-Snout acute or obtuse, wholly or partly cartilaginous, more or less pellucid; shields which arm the body distant from one another. A. Huso, A. dauricus, A. brevirostris, A rubicundus.

2. Sturio.- Snout obtuse or awl-shaped, covered with a bony shield not pellucid; shields distant. A. Guldenstædtii, A. Sturio, A. Lichensteinii, A. Schypa, A. Heckelii.

3. Sterleta.-Snout awl-shaped, covered with bony shields, not pellucid; shields imbricated. A. Ruthenus.

4. Helops.-Snout long (one-sixth or one-seventh of the length of the body), corered with strong bony shields; shields distant. A. stellatus, A. oxyrhyuchus, A. maculosus.

Professor Brandt, subsequently, in the same work, p. 349, reduced the genus into three sections with the following character:- 
1. Huso.-Beards simple, joined togrcther, reaching to the upper lip or beyoul it. A. Huso, A. Schypa = A. Dauricus, Fitz. \&. Heckle.

2. Sturio.-(Formed by nniting Sturio and Helops). Beards simple, ronndish, scarcely united. (A. Sturio, A. Guldenstædtii, A. stellatus.

3. Sterleta.-Beards ronudish, with small nipple-shaped appendages. A. Ruthenus.

Drs. Fitzinger and Heckle, in their monographs of the genus (Amualen der Wienr Museum der Natury. i. 270, 1836), proposed to divide them into two sections, each eontaining three sub-genera, thus :-

A. Dorsal-plates in front sloping and behind highest, ending in at point and open up to the point.

a. The skin covered with small peetinated bony plates. Beards fimbriated.

1. Under lip continnons, (Lionissus.-1. glaber).

2. Under lip not continuous, or a moliment on each side of the mouth. (Acipenseres.-A. Sinensis, A. Gmelni, A. Ruthenus, A. Alentensis, A. maculosus, A. oxyrhychus.

b. The skin cover with larger and smaller peetinated bony scales and larger stellated bony plates. The beards simple: the under lip not continnous, or simply a rudiment on each side of the month. (Ilelopes.-A. stellatus).

B. Dorsal-plates on both sides sloping, highest in the middle, cuding in a point.

a. The skin covered with smaller and larger stellated bouy shields. Beards simple. [uder lip not contimons, or a ruliment om each side of the month. (Antacei--A. Sichypa, A. Guldenstædtii).

b. Skin chagrined, rough, with bhutish bony knobs. The beards simple. Under lip not continuous, or a rudiment only on each side of the month. (Sturiones.-A. Heckelii, A. Sturio).

c. The skin rough, spotted, with pointed bony knobs. The beards flattened, riband-shaped. Under lip not continuous, or a rudiment on each side of the mouth (Husones.-A. hrevirostris. A. rubicundus, A. macrostomus, A. Dauricus, A. Huso.

This arrangement is adopted in this Cittilogue. 
.1. Dorsal-plates sloping in front, higher behiud, ending in a point. and open up to the point.-ACIPEYSER.

Acipenser, A. Filz. f. Heckle, Ann. Wien. Mus. i. 2na, 1936.

1. Dursal-shields in front sloping, behind very high, ending in a point, opea up to the base of the point. Skin corered with small pectinated bony plates. Cirrhi fimbriated. Lower lip continuous. -Lios $I=c e s$

Lionisci, Fitz. Heckle, Ann. Wien. Mus. i. 2ts.

\section{Acipesiser glaber. The Tuk Sichipa or Beluqie.}

Lioniscns glaber, Fitz. S. Heckle, Ann. Wien. Mus. p. 270, t. 25, t. 3, t. 2 ๖. f. $5-6,1 s .36-40$.

Huso II. seu Acipenser glaber, Mars. Dan. Pann. Mys, tom. iv. t. 10.

Acipenser torritus, Mus. Vindob.

Acipenser schypa, Wus. Hindob. Shru, Gen. Zonl. p. 37t, 1404. Acipenser glaber, Heckle, MLS.S. Fitz. e Fiun. Osten, j. $3 \pm 0$. Acipenser nudiventris, Schypa.-Beluga, Lovet. Not. Wag. Jest. T. II. n. $1,2,3$.

Acipenser Marsiglii, Brandt ș. Ratz. Med. Zool. B. ii. Y, 352. Note.

Acipenser schipa, Loret. Diagn. Pisc. ad Gem. Acipense in . Vour. Hem. Soc Wat. Wosc. T. iii. n. 260, t. 17, f. 3, 1, 1×34 (roung). Acipenser schipa, nudiventris, Lovet. $l$ c. t. $13, f, 2, a, b$. (adult).

Hab.-Caspian Sea, Lakes of Siberia. Lake Aral.

2. Dorsal-plates in front sloping, hehind rery high and ending in a point, aud npen up to the base of the point. Skin corererl with small pectinated bont scales. Cirrhi fimbriated. Lower lip not centinuous, or the rudiment only of a lip iu each angle of the muUth.-ACLENSER.

Acipenseres, Fit:. Heckle. Ann. ITien. Mus. i. 269.

Sterlatæ, sp., Brandt. No. I, type Steriatæ, Brandt, No. 2.

\section{Acipevser chisessis. Chinese Sturgeon.}

Acipenser chinensis. Gray, Hard. Illust. Ind. Zonl. pl. 94, i. 5.

1832. Richurdinn, Rep. of the Brit. Assoc.

Acipenser sin-nsis, Gray, Proc. Zool. Soc. pt. 2. p. 122, 1×34

Fiız. Heckle, Ann. Wien. Ifus. p. 275. 1=3b-41).

$H_{\star B}$-China.

n. In spirit: China. Presented by J. R. Reeres, Esq. 
3. Actpesser Guelisi. The Kustera.

Acipenser Gmelini. Fitz. j- Heckle, Ann. Wien. Mus. p. 27ñ. t.

t. 25. 1. 2. t. 3.). f. 17. 1 . 1-3ri-10.

F stera, Gmel. Rris. d. Rusil. iii. 239 adult).

Koster. Ginel. Rers. 1. Rusol. iii. 2:3s roung).

Acipenser siellatu., 3., Ginel. Lim. Syt. Vut. ed. siii. t. p. iii. p. $11-\hbar$.

Acipenver dubius. Heckle. MS.S.

HAB.-Danube. Mus. Vienua.

4. ACIPExer. Rethencs. The Siterlet.

Acipenser. Plin. Hist. Nat. Lih. ix. c. 17. lih. xxxii. c. 51. Mamob. Sat, hib. ii. c. l2. C"icern, Frmyn. Martial. lib. siii. epigr. 41. Orid Halient,

Hus, IT. Cenri, II.. Mirs, Din. Pann. Mys. ir. 35. Ł. 11, f. 2 (old). Hiso III. Tturio I.. Mars. Dan. ir. p. 35, t. 11, f. 1 (roung).

Acipensere, Ic., Flein, Hist. Pisc. Hiss, iv. 13, 4, t. 1. iv. 13. No. 3.

Acipenser, xic.. Linn. Faun. Suec. e 1. 1. p. 27:2.

sterleta. Kc.. Giuld. Vot. Comm. Petrop. xri. 533.

Sterlet. De Bruyn. Reiz. Wns. Pers, en Ind. p. 93. t. 33.

Acipenser ruthenicus, Linn. Wus. Adulph. Fril. I. i. 54, t. 27, f. 2. t. 2-, t. 1. Faun. Suec. ed.2. 5. 30n.

Acipenser ruthenus. Linn. Syst. Sat. ed. sii. t. 1, p. 403, m. 2. Der sterlet. Ginal. Reis. 1. Pussl. B. i. s. 1 12. B. iii. S. 234. Wulff. I.hth. Bir. p. 17, n. 23. Gimel. Limn. sys'. Tat. ed. siii I. i. P. iii. 1' 14-h. Su. 2. Der sterljad,

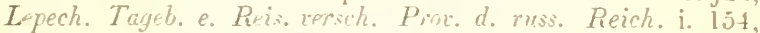
Taf. 9, f. 1, 2. Der Sierlet, Blwch. Oekin. Vaturg. Fische Deutschl. ed. - iii. 125, Taf. -44, ed. 4. B. iii. S. ys, Taf. s9. Sichneider. Bloch. Syst. Ichth. p. 317. No. 2. Miill. Linn. Sat. Sist. iii, 230. Sterlet, shau, Gere. Zool. v. f. ii. P. 375, t. 1b0. Cryied from Bloch). Le Petit Esturgeun. Cur. Ré. Anime td. 1. T. ii. p. 142. ell. 2, T. ii. p. 379 .

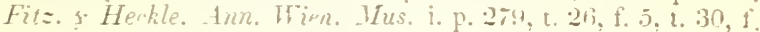
15. 16.

Acipesser Sterletæ Ruthenus (Der Siterlet oder stierl). Brandt i. Ratz. Med. Znol. ii. 21. Laf. 2. I1.-1. 353.

Acipenser ruthenus mium, tc.. For,1. Phil. Truns. 1vii. p. 33.53.

Acipenser promæls, Pull. Ziog. R.sis. fisiat. iii. p. 102, t. 16.

Sturio Hungarolum Ketsege. Gross. Hist. Phys, Regn. Hung. iii.

p. $9: 3$.

Acipenser sturio. Schrank. Faun. Buic. p. 30.5. 
Acipenser strerlet: Daub. Encyl. Méth.

L'Acipensere strelet, Lacep. Hist. Nat. des Poiss. t. i. p. 435.

Le strelet, Dict. Class. vi. p. 318.

Acipenser? Brandt f. Ratz. Med. Zool. ii. 29, Note (adult).

Acipenser Kamensis, or A. Camensis, Lovet. Diagn. Nour. Mém.

Nat. Mosc. iii. p. 262, t. 16, f. 2, $a, b$.

Anat. Kolr. Nour. Comm. Petrop. xvi. 511, t. 14, f. 1-5, xvii. 521 , 1. 10, f. I-11. Brandt, Med. Zool. ii. 24, 353, 354, t. 4 .

Hab.-Caspian Sea. Rivers Volga and Ural.

5. Acipenser Alevtexsis. The Koshadang.

Acipenser Alentensis, Fitz. f. Heckle, Ann. Wicn. Mlus. 285, $1836-40$.

Acipenser rutheno affinis, Pall. Zong. Ross. Asiat. iii. 107.

Acipenser? (dem. Sterlet ahnlich), Brandt \&. Ratz. Med. Zool. ii. S. 25 , Note.

Koshadaug-witsch. Aleutians, Pull.

HAB.-Worth Sea, near Alentian Islands.

6. Acipenser mictuosus. Spotted Sturgeon.

Acipenser maculosus (Spotted Sturgeon), Rafin. Ichth. Ohi. p. 79. Le Sueur. Trans. Amer. Phil. Sore. Phil. N. S. iv. p. 398, 1818. De Kay, Nat. IFist. of Tou York, pt. 1 (Zool.), p. 347,

1812. Fitz.\&. Heckle, Ann. Wien. Mus. i. p. 28.5, 1836.

Acipenser (Helopres) macnlosus, Brandt s. Ratz. Hed. Zool. B. ii. S.

28, Note. Lovet. Nouv. Mem. Mosc. iii. 257, 1844.

HA B.-N. America, Ohio.

a. Stuffed. N. America. From Dr. Parnell's collection.

\section{Acipenser oxyrhynchus. Sharp-nosed Sturgeon.}

Acipenser oxyrinchus, Rafin. Ichth. Ohi. p. 79. Mitch. Trans. Lit. Phil. Sor of New York, i. p. 462. Le Sueur, Trans. Amer. Phil. Soc. Phil. N. S. i. p. 394. Storer, Report on the Fishes of Mussachnsetts, p. 178. De Kay, Nat. Hist. of New York, pt. 1 (Zool.), p. 346, pl. 58, f. 189, 1842 (youmg).

Acipenser oxyrhynchus, C'uv. Règ. Anim. ed. 2, t. ii. p. 380, Note. Lovet. Diay. Acipens. Nonu. Lém. Mosr. iii. 257, 1844.

Fitz. 5. Ieckle, Amu. Wien. Mus. i. p. 286, $1836-40$.

Acipenser (Helopes) oxyrthyuchus, Brandt f. Ratz. Med. Zool. ii. 3,28 , Note, 1843. 
HAв. $\rightarrow$ N. America, Ohio.

a. Stuffed. N. America. Presented by Edward Doubleday, Esq.

b. Stuffed (Young). N. America. Presented by Edward Doubleday, Esq.

c. Stuffed. Gulf of Florida.

d. In spirits. Young. New York. From Mfr. Warwick's collection.

8. Acipenser rupertianus. Land Sturgeon.

Acipenser l'uthenus major, Forst. Phil. Trans. 1xiii. p. 149, I773. Acipenser rupertianus, De Kay, Nat. Hist. of New York, p. 347, pt.

1 (Zool.), 1842. Richardson, Faun. Bor. Am. pt. iii. p. 311, pl. 97, f. 1, $a, b, c, 1836$.

HAB.-N. America.

a. Stuffed. N. America. Presented by Sir J. Richardson.

9. Acipenseres transuontanus. Columbian River Sturgeon.

Acipenser transmontanus, Richardson, Faun. Bor. Am. pt. iii. p. 28I, pl. 97, f. 2, $a, b, c, 1836$. De Kay, Nat. Hist. of New York, p. 347, pt. 1 (Zool.), 1841.

HaB.-Columbian Rirer.

3. Dorsal-plates in front sloping, behind very high, ending in a point, and open to the base of the point. Skin covered with small and largish pectinated bony scales and larger stellulated shields. Cirrhi simple. Lower lip incontinuous, or only rudiments of a lip in either angle of the mouth.- HELops.

Helopes, Brandt \&. Ratz. Med. Zool. 3. Fitz. \&. Heckle, Ann. Wien. Mus. i. 264 (not Fubr.).

Sturiones, sp., Brandt \&. Ratz. Med. Zool. 349.

10. Acipenser stellatus. The Senrnga or Stellated Sturgeon.

Elops, Orid, Halieut. v. 132. Colunella, lib. viii. c. 16. AElian, lib. viii. c. 28. Plin. Hist. Nat. lib. xxxii, c. 54.

Elops Rhodius, Varro. lib. ii. c. 6. Gellius, lib. rii. c. 16.

Huso VI. Antaceus rostratus, Mais. Dan. Pamn. Mys. iv. 37, t. 12, f. 2 .

Acipenser stellatus, Klein, Hist. Lib. Miss. t. iv. p. 14, No. 7. 
Sineruga, \&ce, Giild. Nor. Comm. Petrop. t. xvi. p. 533.

Die Sewrjuga, Lepech. Tageb. e. Reis. d. versch. Prov.d.russ. Reich.j. 156, taf. 10, f. 1, 2 .

Acipenser stellatus, Pall. Reis. B. I. S. 131, \&-Anhung. s. 460, No. 20. Gmel. Linn. Syst. Nat. ed. 13, iii. p. 1486 , No. 5. Schneid. Bloch, Syst. Ichth. p. 348, No. 5. (Stellated Sturgeon). Shaw, Gen. Zool.v. P.II. p. 378. Soreg. Reis. Pise. aq. dule. Hungar. p. 92. Fitz. Prodr. e. Faun. n. Oesterr. Beit. z. Land. Oesterr. I. 340.

A. Helops stellatus, Brandt f. Ratz. Med. Zool. ii. p. 3, iii. f. 3, 1833.

Lovet. Nouv. Mem. Mosc. iii. 257, 262, pl. xviii. f. 1, 1834. Fitz. \&. Heckle, Ann. Wien. Mus. i. p. 257, t. xxvi. f. 6, t. $\mathrm{xxx}$. f. 13, 14, 1836-40.

Acipenser stellatus donensis, Lovet. Nour. Mem. Mosc. iii. p. 263.

Acipenser donensis, t. 19, f. I.

Acipenser Helops, Pall. Zoogr. Ross. Asiat. iii. p. 97.

Acipenser helops, (Le Scherg of the Germans, Sevreja of the Russians), Cur. Règ. An. ed. 2, ii. p. 380.

Acipenser, vc., Fram. Elenc. Pl. \& Anim. Austr. p. 383, No. 3. Acipenser Sturio, Meidin. Icon. Pisc. Austr. Dec. Y.

Lausa Georgianis (Kilische balyk of the Turks), La Mottraye, Itin. ii. p. 88 .

Acipenser Hungarorum, Soreg. Grossin. Hist. Phys. Regn. Hung. iii. 88.

L'Acipensère etoile, La Cep. Hist. Nat. des Poiss. i. p. 439. Dict. Class. d'Hist. Nat. vi. p. 318.

L'Acipensère Senruga, Dict. Class. d'Hist. Nat. vi. p. 318.

Acipenser rostratus, Heckle, MSS.

Sturiones Ratzeburgii, Brandt, Darst. \& Besche, iii. Supp. p. 351, 352 , t. 1, f. $3,1813$.

Var. Monstrosity. Acipenseres stellat oppido rara descripta, Lepech. Nov. Acta. Acad. Petrop. ix. IIist. 35, t. A.

Helopes stellatus, var., Fitz.\& Heckle, Ann. Wien. Mus. i. p. 288, $1 \times 36-40$.

Anat. Marsigli, Damub. vi. t. 21, f. 3, 4. Pall. Zool. Ross. Asiat. ii. 102. Brandt, Ked. Zool. ii. 27, 353, t. 1, f. 11.

Hab.-Caspian Sea.

a. Stuffed. Firth of Forth? Presented by Dr. Stark.

B. Dorsal-plates sloping on to the sirles, highest in the middle, ending ili a point.

Acipenser, B. Fitz. \&. Heckle, Ann. Wien. Mus. i. 270. 
3. Dorsal-plates in front and behind sloping, rery high in the middle, ending in a point. Skin covered with larger and smaller stellulated bony slields. Cirrli simple. Lower lip not continuous, or with only the rudiments of a lip in each angle of the mouth.ANTACEUS.

Antacei, Fitz. S. Heckle, Aun. Wien. Mus. i. 270.

Sturiones, sp., Brandt f. Ratz. Hed. Zool. 3.

\section{Actpexser Sichrpa. The Schip or Smaller Sturgeon.}

A. Antaceus Sclippa, Fitz. I Heckle, Ann. Wien. Mus. i. p. 293, t. xxr. f. 1. t. xxix. f. $9,10,1836-40$.

Scliypa, ve. Giild. Nor. Comm. Petrop. t, xri. p. 5:33.

Schip or Kostera, Lepech. Tagen. Reis. Russ. i. l61. Gmel. Reise d. Russl. I. 142.

Acipenser sturio, var. $\beta$. et $\gamma .$, Pall. Zooyr. Ross. Asiat. t. iii. p. 91 (young). Var. $\beta$. Todum adulta Kostera liossorum, Pall. Zoogr. Ross. Asiat. t. iii. p. 96 (young).

Acipenser Schypa, Gmel. Syst. Nat. iii. p. 1418, No.4. Schneider, Bloch. Syst. Ichth. p. 348, No.6. Sinaller Sturgeon, Shar, Gen. Zool. v. p. 11, p. 374. Fitz. Prodr. c. Faun. r. Oest. Beit. Lund. Oest. B. I. S. 340. Der Sichyp, Brandt \&. Ratz. Med. B. H. S. 20, taf. 1, f. 3, A. B. C. E. S. 350).

Acipenser Güldenstälii, Brandt y. Rutz. Wed. Zonl. B. II. S. 351 . Le Sclype, Dict. Cluss. d'Hist. Nat. t. vi. p. 317.

Acipense medius, Heckle, MSS.

Acipenser Tucka, Mus. Tindub.

HAB.-Russia.

\section{Acipexiser Guldenstanti. Güldenstädt's siturgeon.}

A. Antacens Giildenstädti, Fitz. \&. Heclle, Ann. Wien. Mus, p. 297, t. 27, f. 9 , t. 29, f. $7,8,18: 36-40$.

Antaceus stellaris, Gesn. Par. A. ed Tizpr. p. 1262 (figure). Johnston, Pisc, t. 2s, f. 2. (Copied from Gesner). A. Stellaris or stellatus. Aldrowand, Pisc. ed Bonou: p. 364. (Copied from Gesner).

Antaceus stellatus, Willughby, Pisc Tab. p. 7. (Copied from Gesner). Huso V. Antaceus stellatus, Mars. Dan. Punn. Mys. iv. p. 37, t. 12 .

Acipenser, Lc., Klein, Hist. Pisc. Miss. jv. p. 14. 
Sturio, Sc., Güld. Nor. Comm. Petrop. t. xvi. p. 532. Forst.

Phil. Trans. lvii. p. 3.52.

Acipenser sturio, Pall. Zoogr. Ross. Asiat. t. iii. p. 91 t. 4. Reisinger, Pisc. aquar. dulc. IIungar. p. 88.

Der Stör, Gmel. Reis. d. Russl. B. I. S. 139.

Acipenser, Sc., Kram. Elench. Pl. et Auim. p. 383, No. 3.

Acipenser Huso, $\gamma$., Gmel. Linn. Syst. Nat. ed. xiii. T. I. P. iii. p. 1437, No. 3,7 .

Antaceus Hungarorum (Tok.), Gross. Hist. Phys. Regn. Hung. t. iii. p. 81.

Acipenser hrevirostris, Heckle, MSS.

Acipenser macropthalinus, Heckle, MSS.

Acipenser Kostera, Mus. Vindub., Fitz. Prod.e. Faun. von Oest. Beitr. Sund. Oest. B. I. S. 340.

Acipenser pygmæus (Torpe Tok.), Reis. Pisc. Aquar. dulc. Hungar. p. 93 (young).

Acipenser rostratus, Fisch. Programm. (young).

Acipenser aculeatus, Fisch. MSS. (young). Lovet. Nour. Mem. Mose iii. t. 19, f. 2, p. 257, 262, 1834 .

Acipenser Güldenstadtii (Güldenstüdtischer Stör.), Brandt \& Ratz. Med. Zool. B. ii. S. 13, Taf. iii. f. 2, A.-S. 351, Loret. Nouv. Mém. Soe. Mose. iii. p. 259, t. 17, f. 1, 2. Anat. Marsigli D(mul). vi, t. 19, f, 1, 2, 3. Brandt \& Ratz. Med. Zool. ii. 16, 253, 254 .

Har.-Caspian Sea.

4. Dorsal-plates in front and helind sloping, very high in the middle, ending in a point. Skin rough, granulated, with blunt angled bony plates. Cirrhi simple. Lower lip not continuous, or with rudiments only of a lip in each angle of the mouth.-STURto. Sturio, Fitz. \&. Heckle, An. Wion. Mus. i. 270. Helopes, Brandt \&. Rutz. Hed. Zool.

\section{Acipenser Hecielit. Heckel's Sturgeon.}

A. Sturiones Heckelii, Brandt \& Ratz. Med. Zool. B. iii. p. 3, 1833. Fitz.\& Heckle, Ann. Wien. Mus. B. i. p. 303, t. xxri. f. 4, t. xxix. f. $11,12,1836-40$.

A. Sturiones Geckelii, Loret. Nour. Mrm. Mose. B. iii. p. 257, 1834. Galeus Rhodius, Rond. de Pisc. Amr. 1. 176 (figure). Gesn. Aquat. p. 720. (Copied from Rondelet). Aldron. de Pisc. p. 532. (C'opied from Rondelet). 


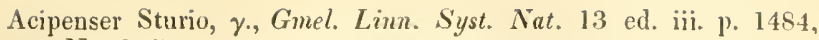
No. 1, 7.

Acipenser Platycephalus, Heckle, MSS. (young).

Acipenser Heckelii, Fitz. MISS.

Acipenser Huso? Nard. Prod. Obs. Disq. Adr. Ichth. Tic. Rey. 1827,4, p. 10, No. 36.

Acipenser lutescens, Rafin. Ichth. Ohi. p. 79.

Acipenser Naccari, Bonap. MSSS. (young).

Acipenser Sturionellus, Nard, MSS. (young).

Hab.-Mediterranean.

a. Stuffed. Adriatic. From Dr. Heckle's collection.

\section{Acipenser Atillis. Common Sturgeon.}

Sturiones Sturio, Brandt \& Ratz. Med. Zool. B. iii. p. 17, t. iii. f. 1, 1833. Loret. Nouv. Mém. Mosc. t. iii. p. 257, 1834. Fitz. S. Heckle, Ann. Wien. Mus. B. i. p. 307, t. xxvii. f. 8, t. xxviii. f. 3, 11, 1836-40.

Attilus, Plin. Hist. Nat. Iib. ix. c. 17. Belon, Hist. Nat. des Estranges Poissons Marins, fol. 13. (young). Rondelet, de Pisc. fluriat. p. 173. Gesn. Aquat. p. 126. (Copied from Rondelet).

Attilus piscis Eridano peculiaris, Belon, de Aquat. L. J. p. 102 (young).

Adano, Belon, La Nature et Dixersité des Poissons, L.J. p. 94.

Attilns Rondeletii, Pade, Willoughby, Ichth. p. 24I, t. p. 7, f. 2. (Copied from Rondelet).

Attilus verus ex Pado, Aldrov. Pisc. L. v. p. 563 . Jonston, Pisc. t. 28, f. 4. (Copied from Aldrovand).

Sturio seu Silurus, Salv. Hist. Aquat. Anim. fol. 113, t. 112, p. 31 .

Sturio Acipenser Salvian, Willoughby, Ichth. p. 239, t. p. 7, f. 3.

(Copied from Salian).

Sturio, Rondelet, de Pisc. Marin. p. 410 . (young).

Strrio primus et secundus, Gesner, Aquat. p, 73. (young).

Sturiones dno genera, quorum prius Venetis Morano vocatur, Aldror. Pisc. L. iv. p. 526. (Copied from Gesmer).

Acipenser verus a Mattiuo, Fox. Med. Crac. Miss. Aldron. Pisc. L. iv. p. 527. (young).

Acipenser seu Sturio, 2 et 3, Jonstom, Pisc. (young).

Acipenser Sturio, Jonston, Pisc. t. 28, f. 8. (Copied from Salvian). Blas. Anat. An. t. 49, f. 12. (Copied from Salvian). Linn. Syst. Nat. ed. xii. t. i. p. 103, No. 1. Mïll. Prod. Zoot- 
Dan. p. 31, No. 322. (Der Stöhr.). Bloch, Occanom. Natury. d. Fisch. Deuts. ed. in 4to, 1. iii. p. 89, t. 88, ed in 8ro, t. iii. p. 113, t. 83 . Gmel. Limn. Syst. Nat. ed. 13, iii. p. 1483, No. 1. Znm. Theile. Bloch, Syst. Ichth.ed Schneid. p. 347, No. 1. Common Sturgeon, Shaw, Gen. Znol. v. P. ii. p. 370, t. 159. (Copied from Bloch). Acipenser Esturgeon, Riss. Ichth. Nice, p. 56. Nard. Prodr. Obs. et Disq. Adr. Ichth. p. 10, No. 35. Fab. Nat. Fische Islands, p. 46. Esturgeon ordinaire, Risso. Hist. Nat. de l'Europe Merid. t. ii. p. J66. Cur. Règ. An. 1 ed. t. ii. p. 142,2 ed. t. ii. p. 379. Don. Brit. Fish. pl.65. Flem. Brit. Anim. p. 173, s. 30, 1828. Jcn. Man. Brit. Vert. p. 493, s. 183. Yarr. Brit. Fish. 2 ed. ii. p. 475,1841 .

Acipenser, ce., Klein, Hist. Pisc. Miss. iv. p. 12, 13. (young). Acipenser, Sc., Art. Ichth. Gen. p. 65, No. 1. Syn. p. 91, No. Limn. Faun. Succ. 1 ed. p. 2\%. Grom. Mus. 1. ij. 1. Gron. Mus. t. i. p. 60, No. 131. Gron. Znoph. p. 39, No. 140.

Acipenser, Linn. It. Scund?. p. 187.

Acipenser europæus, Limr. Faun. Suec. 2 ed. p. 299. Limn. Mus. Adolph. Frid. t. i. p. 54, t. 18, Fr. 2.

Sturgeon, Raii, Syn. Pisc. p. 112. Penn. Brit. Zool. t. iii. p. 124, t. 19 (young).

Störe oder Stoije, Pontop. Nort. Nat. Hist. t. ii. p. 288.

Styria Olass, Isl. Reis. $\$ 745$.

Stoijes, Leem. dc Lapp. p. 326.

Stobre, Tukalla, Fisch. Nat. r. Liegt. p. 113.

Stoer, Sand. Naturf. t. xx. p. 163.

Sturio, Charl. Onom. Zoic. p. 158.

Esturgeon, Bouss. Nat. Aquat. Carm. p. 174. (young).

L'Esturgeon, Du Ham. Trait. t. iii. s. viii. pt. 1, p. 221.

L'Esturgeon commun, Dict. Class. dHist. Nat. t. vi. p. 315.

L'Acipensere Esturgeon, Lacep. Hist. Nat. Poiss. t. i. p. 411.

Accipenser attilus, Rafin. Ichth. Ohi. p. 79.

Seba Thesamus, t. iii. p. 101, 1. 29, s. 19.

Var. Monstrosity, Acipenser Lichtensteinii, Bloch, Syst. lchth. ed Schn. p. 348, No. 4, 69. Brandt \& Ratz. Med. Zool. t. ii. p . ?I, Note, t. ii. p. 1, $a, b, c, 352$. Lmet. Now'. Mém. Mose. i. iii. p. 257 .

HAB.-North Seas.

a. In spirits. Young.

b. Stuffed. English Coast.

c. Stuffed. Young. (Old collection). 
15. Acipenser latirostris. The Broad-nosed Sturgeon.

Acipenser latirostris, Parn. Trans. R. S. xiv. pl. 4. Paln. Fish of Forth. Wern. Ment. vii. p. 405, pl. 39. Yarr. Brit. Fish. 2 ed. ii. p. $479,1841$.

Hab. - North Seas.

a. Plates of the head. Berwick-upon-Tweed. Presented by Dr. Johnston.

5. Dorsal-plates in front and behind sloping, rery high in the middle, ending in a point. Skin rough, spotted over with sping bony scales. Cirrhi compressed, ribband-shaped, clothed. Lower lip not continuous, or with rudiments only of a lip in each angle of the moutl. - Huso.

Huso, Fitz. \&. Heckle, Ann. Wien. Mus. i. 270.

Husones, Brandt f. Ratz. Med. Zool. i. 349.

16. Acipenser brevirostris. The Round-nused Sturgeon.

Huso brevirostris, Fitz. \& Ileckle, Ann. Wien. Mus. p. 313, 1836 $-40$.

Sturio, Back. Nat. Hist. Car. p. 236. Forst. Phil. Trans. Ixiii. p. 150. Forst. Beit. zur Volk. \&. Lünder. b. iii. s. 259.

Acipenser Huso, Aus New York, Mus. Bloch.

Acipenser Sturio (Round-nosed Sturgeon). Mitch. Trans. Phil. Soc. New York, i. p. 461.

Acipenser brevirostrum, and varieties, Lesuem, Trans. Amer. Phil. Soc. (N. S. i. 390). Rafin. Ichth. Ohi. p. 79.

Acipenser brevirostris, Cuv. Rèy. An. ed. 2, t. ii. p. 380, Note. Brandt \&. Ratz. Med. Zool. h. ii. s. 13, Note, taf. 1, f. 2, G.

De Kay, Nat. Hist. New York, pt. 2 (Zool.), p. 345, 1842. Acipenser marginatus, Rafin. Ichth. Ohi. p. 79.

Acipenser hudsonius, Rafin. Ichth. Ohi. p. 79.

Acipenser atlanticus, Rafin. Ichth. Ohi. p. 79.

Acipenser maculatus, Canada, Varietas Husonis, Reis. Pisc. Aquar. Hung. p. 91, Note.

Acipenser obtusirostris, Lovet. Nouv. Mém. Mosc. t. iii p. 25\%. HaB.-N. America.

a. Stuffed. N. America. Presented by Edward Doubleday, Esy. 
17. Acmexser mubicuxdus. The Lake Sturgcon.

Husones rubicundus, Brundt of Ratz. Med. Zool. ii. 3, 1833. Lor. Nour. Mém. Mose. p. 257, 1834. Fitz. f. Heckle, Ann. Wien. Mus. i. 316, 1536.

Acipenser rubicundus, Le Suer, Trans. Aner. Phil. Sroc. (N. S.) i. 1. 3s8, t. 12, alt. First variety, Le Suer, l. c. p. 389 (young).

Sccond variety, Le Suer, l. ¿. 1. 390 (young). Cur. Rèy. An.

2 ed. t. ii. p. 380, Note. Dict. Class. d'Ilist. Nat. t. vi. 1). 319. Brandt f. Ratz. Mell. Zool. ii. 13, Note. De Kay. Nat.

Ilist. Now Yorl, pt. I (Zool.), p. 314, pl. 5s, f. 191, 1812.

Acipenser rubieundus, Rafin. Ichth. Ohi. p. 79 (old).

Ieipenser scrotinus Rafin. Iehth. Ohi. p. 80 (uld).

Acipenser muricatus, Rafin. lehth. Ohi. p. 79) (young).

Acipenser ohiensis (Ohio Sturgeon), Rafin. Ichth. Oli. p. $\times 1$. (young).

HAB.-N. America.

18. Acipexser nacrostomis, The Big-month Sturgeon.

Husoses macrostomus, Fitz. f. Heckle, Anu. Wien. Mus. i. 317, $1836-40$.

Aeipenser macrostomus (Big-mouth Sturgcon), Rafin. Ichth. Ohi. p. 81.

Acipenser lagenarius (Gourd-fish S'turgenn, Esturgion gourle), Rafin. Ichith. Ohi. p. 86 .

HAB.-N. Americi.

19. Acipexser diurices. The Daurian Sturgeon.

Husones damricus, Brendt f-Ratz. Med. Zool. i. 3, 1829. Loret. Nour. Mém. Mosc. iii. 257, 1834. Fitz. F. Heckle, Aur.

Wien. Mus. i. 318, 1836.

Acjpeuser kaluschka, Stella, Obs. Ichth. MSSS.

Acipenser dauricus, Georyi, Bemerk. e. Reise. i. Russ. Reich. B. I.

S. 352. Brandt S. Ratz. Med. Zool. ii. s. 12, Note.

Aeipeuser orientalis, Pall. Zoogr. Ross. Asiat. t. jii. p. 107.

Acipenser Schypa, Monet. Cat. Rais. Otj. Zool. 1832, 4, p. 79, Brandt s. Ratz. Hed. Zool. ii. s. 350), 352, taf. 1, a, f. 2. F. $-\mathrm{K}$.

Acipenser husonifurmes, Loiet. Nonv. Mém. Mosc. t. iii. p. 258, t. $16, \mathrm{f} .1, a, b$.

Hab.-Caspian Sea. 
20. Acrpexser Huso. The Isinglass Sturgeon.

Husones Huso, Brandt f. Ratz. Med. Zool. i. 3, t. 1, f. 1 (yomme). Supp. t. 1, f. 1, A.-E. p. 349, 352, 1829. Loret. Nour. Vém. Hosc. iii. 258, t. 15, f. 1, a, b, 1834. Fitz. 5. Heckle, Anu. Wien. Wus. i. 320 , t. xxvii. f. 7, t. xxviii. f. 1, 2, 1836 .

Mario, Pliu. Hist. Nat. Lib. ix. c. 1.5.

Ichthyocolla, Plin. Hist. Nat. Lib. xxxii. c. 7. Bell. Aquat. Lib. i. p. 104. Raii, Siyn. Pisc.p. 114.

Ichthyocolla seu Piscis exus, Romel. Pisc. Aur. p. 177. Ges. Ayuat p. 57. Jonston, Pisc. 1. 25, f.t.

Ichthyocolla Rondeletii et Bellonii, Will. Ichth. p. 244.

Huso, Albert. Magn. Lib. xxiv. de Anim. Gross. Ln. Hist. Phys.

Regn. Huny, t. iii. p. 62. Charl. Onom. Zoic. p. 153.

Antaceus Borysthenis, Roud. Pise. fur. p. 187. Ges. Aquat. 1.

56. Aldrov, Pisc. Lib. v. p. 564.

Huso seu Antaceus, Ges. Aquat. p. 59.

Huso Gesneri, Aldrovand, Pisc. p. 5:34.

Huso Germanorum, Huso Danuhii, Will. Ichth. p. 24:3, 7. f. 1. Jonston, de Pisc. p. 116, t. 25, 1. 13. Raii, Siyn. Pisc. 1. 113, No. 4.

Huso I., Verus et genuinus, Mars. Dan. Pann. Mys. ir. 31, t. 14. f. 1 .

Acipenser, Lc., Klein, IIist. Pisc. Miss. is. 11.

Huso, tc., Gïlld. Nox. Cumm. Petrop. xvi. 5:32.

Beluga, Gmel. Alb. Forst. Phil. Truns. Wiii. 354.

Acipenser, sc., Gram. El. Pl. et An. Aluct. p. 5is,3, No. 1.

Acipenser tuhercules varens, Art. Ichth. Gen. p. 65, No. 2, siyn. 1. 92, No. 2.

Acipenser Huso, Limn. Syst. Nat. ed. xii. 40i, No. 3. (Hel Hausen). Lepech. Tageb. d. Reis. d. r. Prot. d. Russ. Reich. j. 15s, t. ii. 1. 1, 2. Pall. Reis. j. 131, ii. p. 3339. Pull. Zungr. Rossto. Asint. iii. p. s(i, t. 13). (Der Hitusen). Blush. Netury. Ausl. Fisch. ed. in 4, i. p. To, t. 1:2!, ed in \&. i. 1). 105, 1. 129. Mrid. Icom. Pisc. Lustr. (('upied from Bloch). Gmel. Linn. Syst. Nat. ed. xiii. j. p. 14s\%, Nü. 3. Block. syst. Ichth. ed. Schneider, 1. 34, No. 3. Schrunk, Frun. Boic. ii. p. 30t. (Isinglass Sturgeon). Shau, Gen. Loml. ․ ii. p. 375, t. 159. (Coppied trum Bluch). Reis. Pise. Aquar. Dulc. Hun. p. 91. Fitz. Prodt. r. Faun. Oest. Leit. z. Land. Oest. B. J. Ś. 340. (Hausen).

Acipenser huso (Le Hallsen on Grand Esturgeon), Cur. Rey. An. I ed. ii. p. 142, 2 ed. ii. p. 380. 
Le Grand Esturgeon, Valm. de Bomare. Dict. d'llist. Niat. ir. p. 293.

Acipenser Iehthyocolle, I'Aub. Ene. Meth. i. Bonat. Enc. Meth. i. L'Acipenser Huso, Lacép. II ist. Nat. des Poiss. i. p. 4:2.

IA and Danube.

\section{SCAPHIRHYNCHUS.}

Nose depressed, convex and shielded above, concave beneath. Mouth inferior, with four beards in front. Bodly fusiform, with five series of shields; hinder part of body depressed, covered with scales.

Seaphirhynchus, Heck. Ann. Wien. Mus, Nat. i. 72, 1 s:36.

Acipenser, sp., Rafin. Ichth. Ohi. so. Gray, Proc. Zoul. Soc. ii. $122,1834$.

1. Scaphirhynches cataphractes. Shovel-fish.

Acipenser cataphractes, Gray, Proc. Zool. Soc. pt. ii. 1. 12.2. 1834.

Seaphirhynehus Rafinesquii, Heck. Aun. Wien. Wus. i. p. 72, t. \$, p. $326,1836-40$.

Lcipenser platyrhynchus (Shovel-fish Sturgeon), Rafin. Ichth. Ohi. p. 80,1820 .

H.в.-N. America, River Ohio, tc.

a. Stuffert. Adult. From Mr. Salle's collection.

b. Stuffed. Half-grown. From Mr. Salle's collection.

e. Stuffed. Hatf-grown.

\section{3. : DINECTES.}

Dorsal-fins two.

Dinectes, Rafin. Ichth. Ohi. \$2, 1820.

1. Dinectes trinchus, Flat-nose Double-fin.

Dinectes truncatus, Rafin. Ichth. Ohi. p. s2, 1820.

Hab,-IIendersonville, Audubon. 


\section{4. ? PROCEROS.}

Proceros, Rafin. Ichth. Ohi. 87, 1820.

1. Proceros maculatus. Spotted Hornfish.

Proceros maculatus, Rafin. Ichth. Ohi. p. 87, 1820.

H九b.-N. America, Lake Ontario.

2. Proceros vittatus. Striped Horufish.

Proceros vittatus, Rafin. Ichth. Ohi. p. 87, 1820.

Hab.--N. America, Mississippi and St. Genevieve, State of Missouri.

\section{Fam. 2. POLYODONTIDE.}

Body without any tubercles or horny plates.

Les Polyodons, Lacép. 1, xii.3. Cun. Rég. An. ii. 2 ed. 380, 1829. Brach. Nutla seu Spathulariæ, Miell. Abh. Akad. Berl. 1836. May. Zool. \&. Bot. i. 405.

Spatularia, Shaw. Zool. 362.

Les Sturiones, p., Cuv. Règ. An. 2 ed, ii. 378.

Sturioni, p., Rafin. Anal. Nat. 92, 1815.

Prionidæ, Swains. Lard. Enryc. 322, 1839.

Polyodontidæ (Polyodontini), Bonap. Syst. Ichth. 13, 183s

\section{POLIODON.}

Polyodon, Lacép. Ichth. i. 403, 1798. Swains. Lard. Encyc.,322, 1839.

Planirostra, Rafin. Ichth. Ohi. 83, 1820. Lesueur, Jour. Acad. N.

S. Philad. i. 229. Heckle, Ann. Wien. Mus. i. 72, 1836. De Kay, Nat. Hist. of New York. 347.

Prionodon, Swains. Lard. Encyc. 191, 1839. 
1. Polyonox spatulat. Spoonbill Sturgeon.

Squalus spatula, Mand. Jour. Phys. pl. ii. n. 1774.

Le Pulyodon fenille, Lacép. i. 403, pl. 12, f. :3, 1798. Dict. Sei. Nat.pl. , 1816-30. Cur. Règ. An. 2 ed. ii. $380,1829$.

Polyodon folium, Schneid. Bloch, Syst. Ichth. 1. 457, pl. 622,

f. 1, 1801. Rich. Faun. Bor. Am. pt. iji. 278, 1836.

Spatularia reticulata, Shau, Gen. Zool. v. pt. ii. pl. 156, 1. 3(i2, 1804.

Polyodon folium (Paddle Fish), Sill. Jour. xii. 201, pl. , f. I, 2, 3, 7,1824 .

Polyodon reticulatus, Swains. Lard. Cab. Cycl. i. 1:2.2, f. 7, ii. 3222, $1838-39$.

Spatulitria, Müll. Mem. Acad. Berl. p. 74-211, 1834.

Platirostra edentula, Rafin. Ichth. Ohi. p. 83, 1820. Lesueur, Phil. Ac. Nat. Sci. ii. 288, 1817-18. Say, App. Sengl. Exped. 254. Rich. Faun. Bor. Am. pt. jii. 278, Is36. De Kay, Nat. Hist. New Yorli, pt. i. (Zool.) 347, 1841 .

HAB.-N. America, Ohio.

a. Stuffed. Mrississippi. From Mr. Salle's collection.

b. In spirits. Mississippi. From Mr. Salle's collection.

c, $d, e$. In spirits. Mississippi. From Mr. Salle's collection.

$f$. In spirits. From Mr. Mather's collection.

\section{Section B. CHIIERIA.}

Chimera, Lim. Syst. Nat.

Ch. Holocephala. Mïll. Abh. Akal. Berl. 1836. Mag. Zool.|s. Bot. i. 408.

Les Sturioniens ou Ch. a branchies libres (part), Cur. Rig. An. ii. 1817,2 ed. ii. 378,1829 .

Holocephali, Brown, Index Puleon. 636.

Chismopnes, part., Dum. Zool. Anal. 105, 1806.

Les Chimeres, Cur. Règ. An. 2 ed. ii. 381.

Chismopnea Branchismea, p., Rafin. Anal. Nat. 92, 1815.

Chineria, Rufin. Anal. Nat.92, 1815.

Chimæradæ, Gray, Syn. B. H. 147, 1812.

Chimæridæ, Suains. Lard. Encyc. 32:, 1839. Gray, Syn. B. M. 150, 1842. Agassiz. Brown, Index Paleon. 636. Bonap.

Syst. 1chth. 13, 1838.

Acanthorrini, Bonap. Syst. Ichth. 13, 1838.

Chimærini, Bomay. Syst. Ichth. 13, 1838. 


\section{Fam. 1. CHIMERADA.}

Character of the order. - Symopsis of the genera.

1. Chimera.-Beak conical. Dorsals nearly contiguous.

2. Callorhynchus.-Beak endiug in a foliaceous appendage. Dorsals remote.

\section{CHIMERA.}

Beak conical. Dorsals nearly contiguous.

Chimmra, Cur. Règ. Au. 2 ed. ii. 382.

Chimæra, sp., Linn.

? Ischyodon and ganodus, Eyerton.

? Psittacodon, Agussiz.

\section{Chumera monstrosa. Northern Chimæra.}

Chimæra monstrosa, Limn. Gmel. 1408. Selneider, Bloch, Syst. Ichth. p. 349, 1801. Bomap. Icon. Fann. Ital. pl. 1×32-41. Swainson, Lard. Cyel. ii. 323, f. 101, 1839. Gaim. Foy. Pol. Poiss. t. 20 .

Roi des harengs du nord, Daub. Enc. Weth. Bonnat. Pl. Ene. Meth. i. Fentr. Suce. 294. Gunn. Act. Nirl. ii. 270, t. 5, 6. Mill. Prod. Zoul. Dan. p. 3s, n. 320. Olaff. Isl. i. 19.2. Bloch, Pl. 124. Mtus. Ad. Fr, i. 53, t. 25.

Chimæra argentens, Limn. Ascan. Ic. Rer. Nat. t. 15. (mas.)

Galeus acanthius C'lusii exoticus, Will. Ichth. p. 57, t. B, 9, f. 9. Rai. 1. 23, 1. 15. Gssn. Aquat. p. .77. Icon. An. p. 153. Simia marina, Jonston, Pist. p. 29, t. i. f. 6.

Centrina veri, Simia marma dicta, Alelme. Pisc. p. 102, 103, 405. Vulpecula, strem sandm, p. 2s:t.

La Chimere Aretique, Lacép. i. p. 392, pl. 19, f. 1 (female), 179s. Cut. Rèy. An. 2 edit, ii. 352, 1529.

Northern Chimra, Shave, Gen. Zoml. v. pt. ii pl. 157 (male), 1804 .

H.A.-Nortl Sea.

a. In spirits. Male.

2. C'ntm.era Colbier. Cohley's Chimæra.

Chimæra Colliei, Bennett, Betech. I'oy. p. 71, pl. xxiii. 1839. HAB.-Northeru parts of the Pacific Ocean 


\section{CALLORHY NCHUS.}

Beak ending in a foliaceous appendage. Dorsałs far apart. Callorhyochus, Gronov. Mus. 59. Cuv. Rég. An, 2 edit. ii. 382. Climæra, sp., Gmel. Syst. Nat. i.

\section{Calzorhycuus antarctica. Southern Chimæra.}

Callorlynchus antarctica, Gron. pl. 4, f. 1, 2. Swainson, Lard. Cab. Cycl. ii. 32:3, 1839.

Chalgua Achagual, in Araucanian.

Chimæra eallorhynchus, Gmel. Syst. Nat. i.

Roi des harengs dı sud, Danb. Enc. Meth. i. Bonn. Pl. Enc'. Meth. i.

Callorlynchus, Gronot. Nus. 59, 1. 130, t. 4.

Pejegallo, Frez. It. i, 211, t. 17, f. 4.

Elephant Fish, Ellis, Cook's First Voyage.

Poisson coq., Molina, Essai sur l'Ilist. Nat. du Chili, $20 \%$.

Le Chimère Antarctiq̨ne, Lacép. i. pl. 12 (female), p. 400, 1799. Cuv. Règ. An. 2 edit. ii. $382,1829$.

Chimæra Australis, Southern Chimæra, Shaw, Gen. Zool. v. pt. 11, pl. 158 (male), 157 (female), p. 368, 1804.

H.1.-Southern Ocean.

a. In spirits. Australia. Presented by the Zoological Society of London.

\section{Sub-order II. TREMATOPNEA.}

Gills fixed by their onter edge to the intervals between the lateral branchial opening.

Trematopnes, Dum. Zool. Anal. 101, 1806.

Chondropterygiens ì branches fixes, Cur. Règ. An. 2 ed. ii, 383. Trematopnea, part (Plagiostomia aud Cylostomea), Rafin. Anal.

Nat. i. 1815.

\section{Section C. PLAGIOSTOMII.}

Plagiostumes, Dum. Zool. Anal. 103, 1806.

Plagiostomia, Rafin. Anal. Nat. 93, 1815. 
Plagiostomata, Müll. Abh. Akad. Berl. 1836. Mag. Zool. d. Bot. i. 405 .

Pisces cartilaginei, Ray, Sym. Pisc. 28.

Selaciens (Plagiostomes) Cuv. Rig. An. 2 ed. ii. 383.

Selaca (Selaque), Bluin. Bull. Soc. Phil. 112, 1826.

Selacha (Plagiostoma), Bonap. Selach. Fulula Analitica, 1838, 4 to. Plagiostumi, De Kay, Nat. IIist. of New $Y_{m} \%, 348$.

1I. De Blainville (Bull. Soc. Phil. \&. Jour, de Phys. 260, 1816), proposed to form the flat-hodier cartilagineous fish into a sub-order, which he ealled Selaca, and divided it into three genera:-1. Ruia. -2. Squntina.-3. Squalus.

Müller and Henle (Mag. Nat. Hist. ii. 1838) separate the Plagiostomi into two orders, 1 skates (Raic), 2 Slarks (Squali); the fomer characterized by the existence of a peculiar cartilage arising from the nasal part of the skull and extending towards, and even meetiug to form the anterior part of the crest of the pectoral-fin: there is no trace of this cartilage in the sharks.

\section{Sinopis of Finilies.}

I. Squali._Skull without any froutal cartilagc ; branchial openings lateral.

1. Scrlbiad E.-Body elongate, subcylindrical; pectoral-fins moderate; lateral part of the dorsal-fins orer or behind the abdominal-fin.

2. Squazrde.-Body clongate, subcylindrical; pectoril-fins moderate : lateral dorsal one or two first before the abdominal-fin.

3. SQLATIxaD.E.-Body rather depressed; pectoral-fins very large.

2. Raii.-Skull with a peculiar frontal cartilage from the nusul, extending in front and meeting, forming the front crest of the pectoral-fin; branchial-opening inferior.

4. Pristrside.-Body elongate, gradually tapering into the tail.

5. RarBf.-Body much depressed, broad, abruptly ending in a slender tail. 


\section{Sub-section I. SQLALI.}

Gill-openings lateral; cyclids free; supplementary humeral girdle incomplete; heal cartilage none.

Squalus, Lim. Siyst. Nut.

Antacea, Rafin. Anal. Nat. 93, 1815.

Les Siquales (S'qualus), Cur. R'ंg. An. 2 ed. ij. 385.

Les Marteanx ('Zygæna), Cur. Règ. An. 2 ed. ii. 394.

Squali, Miill. Abh. Alad. Berl. 1836. May. Zool. f. Bot. i. 403.

Miill. \&. Honle, Mag. Nat. Hist. ii. 1835. Playjost.

Squalidx, Bomap. Selac. Tab. Anal. 1838. Swains. Lard. Encye.

191, 312, 1839. Gray, Syn. B. H. 148, 150, 1842. De Kay,

Nat. IIist. of New York. 348.

Squatina and Squalus, Bluin. Bull. Soc. Phil. 121, 1816.

Pisces Cartilaginei longi, Ray, Syn. Pisc. 18.

Limmæus (Syst. Nat. i. 397) formed the sharks into three sections: -1 . Dorsal-fin spinous, anal-fin none. $-S$. Acanthias. 2. Dorsalfin unarmed; anal-fin listinct ; teeth acute.—S. Zygona. 3. Teeth granulated.-S. mustellus.

Schneider (Syst. Ichth. 1801) divides them thus:-1. Spiracle and anal-fin distinct.-S. cunicula. 2. Spiracles none; anal distinct.-S. Zygrena. 3. Spiracles distinct; anal none.-S. centrina.

Rafinesque (Caratteri Nuori Generi, 1810, Svo.) described and figured the following new genera and species of sharks: - I. Carcharias Taurus, 10, t. 14, f'. 1.-2. Delatias sparophagus, 10, t. 1:3, f. 4.-3. D. nocturuus, 11, t. 14, f. 3. - 4. Tetroras angivora, 11.5 . Isurus oxyrhinchus, 12, t. 13, f. $1 .-6$. Cerictius macrourus, 12 . - 7. Alopias macrourus, 12.-8. Heptranchias cinereus, 13.9. Galeus melastomus, 12. - 10. Squalus uyato, 12, t. 14, f. 2.11. Hexanchus grissus, 12. - 12. Etmopterus aculeatus, 14, t. 13, f. 3. In his 'Analyse de la Nature,' 1815, he quoted these genera, and added the following, but without characters or quoting types:13. Sphyrnias. - 14. Oxynotus. - 15. Squalina, Dum. - 16. Pristes, Lath.-17: Anodon, Lac.

II. De Blainville (Bull. Sor. Phil. 121, 1816, and four. de Phys, 260, 1816) divides the Squali in nine sub-genera, thins:1. Scyliorhinus (canicula) - - 2. Echinorhinus (spinosus). - 3. Monopterhinus (griseus).-4. Galeorhinus (mustelus).-5. Acauthorbinus (acantheus). - 6. Heterodontes (Philippii). - 7. Carcharhinus (Lamia).-8. Cestrorhinus ( $\angle$ ygæa).-9. Cetorhimus (Gunneri). 
Cuvier (Règ. An. 385, 1817, and 2 ed. 1829) divides these animals in the following manner:-I. Squalus (Linn.), containing

I. (Les Scyllies).

II. Les Squales, which are sub-divided as in Sclıneider, thus: a. without spiracules and without anal-fus. 1. Carcharias,-2. Lamna. b. with spiracules and anal-fins.-3. Galeus. - 4. Mustelus.-5. Notidanus.-6. Selache.-7. Cestraciens. c. wilh spiracules, but without anals. - 8. Spinax. - 9. Centrina.-10. Scymnus.

-11. Zygæna.

III. Squatina.

IV. Pristis.

M. Charles Buonaparte (Selachorum Tabula Analytica, 1838, 4 to.) divides the family Squalidæ in the following manner:-

1. Squalidæ anomalæ.-Body depressed. Pectoral-fins very large. -Squatina.

2. Squalidæ veræ. - Body elongate, roundish; pectoral-fins congruous.

* Anal-fins nome; spiracles distinet; nictitant membrane none.

1. Spinaciui.-First dorsal spined; teeth compressed, sharp-edged.Acanthias.-Spinax,-Centrina.-Centrophorus.

2. Seymnini. - Dorsals armless; teeth triangular, of maxilla, in many series; of mandibles, in one or two series, and a broad base. Lepidorhinus.-Scymnus.-Læmargus.—Echinorrhinus.

** Anal distinct; nictitant membrane none; spiracles none, or very small.

3. Notidianini.-Dorsal, one.-Heptoranchias.-Nutidianus.

4. Trichoghidini.-Dorsals, two ; first before, second behiud the rentrals and before the anal; gill-slits very large, all before the pectoral; fins large; upper candal-lobe elongate.-Triglochis.

5. Lamnini.-Dorsals, two; second opposite the small anal; gillslits very large, all before the pectorals; tail lunate. - Selache. Carcharodon.-Oxyrhina.-Lamua.

6. Alopiadini.-Dorsals, two; hinder over the pectorals; upper caudal-lobe very long; gill-slits small; teeth simple. - Alopias. Rhinzodon. 
** Anal distinet; nirtitant membrune distinct; hinder gill-slit orer the pectorals; second dorsal opposite the unal; dorsal unarmed.

7. Squalini.-Teeth eompressed, triangular, acute; spiracles nome, or small. - Splyrna. - Squalus. - Thalassorhinus. - Scoliodon. Galeocerdo,-Physodun.-Loxodon.-Galens.

8. Trimodontini.-Teeth acule, denticulated ou each side; spiracles small.-'T'riakis.-Leptocharias.-Triænodon.

9. Musteiini.-Teeth smull, blunt; spiracles large.-Mustelus.

10. C'estracionini.-Anal distinel; nietilant membrane none; spiracles large; gill-slits small; hinder over the pectorals; dorsals armed with spines. - Cestracion.

11. Scyllini. - Anal distinct; nictitant menbrane nome; spiracles large; dorsals both nearly orer the rentrals: teeth small, acute, denticulated. - Stegistoma. - Uglismostoma. — Grassorhimus. Hemiscyllium. - Orectolobus, - Pristidurus.-Scyllium. -? Rhinaodon.

Dr. S. Müller and Hente (May. Nat. Hist. ii. 1838) pulblished an outline of their system. He divides the sharks into five divisions, thus :-

Dirision I. Seyllin, containing 1. Serllimm. - 2. Pristiurus. 3. Chiloscyllium. - 4. Hemiseyllum. - 5. Crossorhinus. -6. Ginglymostoma.-7. Stegustoma.

II. subdivided thus: a. with membrann niclitans. a. without spiracles. a. teeth flat, sherp-edged, servated, or smooth. 1. Carchavias. - 2. Scoliodon. - 3. Zygana. b. tecth pointed with a lateral denticle-like tooth of Scyllizin. 1. Trixnodon. -2. Leptocharis. B. with spiracles. a. teeth flat, part serrated, or not serrated. 1. (raleocerdo. - 2. Loxodon. - 3. Galeus. b. teeth pointed, as in scyllium. 1. Triakis. e. teeth parement-like. 1. II ustelıs, - 2. No nictitating membrane (Lamnoidea). 1. Lamna. - 2. Oxyrhina. -3. Carcharodon. - 4. Selache. - 5. Rineodon. b. Trichoghis. c. Alopecias.-d. Cestracion.

III. Notidanus, Cuvier. 1. Hexanchus.-2. Heptanchus.

It. a. Acanthorims. 1. Acanthias. - 2. Spinax, - 3. Centrina. -4. Centrophorus. b. Seymnus. 1. Sesmuns. - 2. Lemargus.3. Echinorminus.

Y. Squatiua. 


\section{Fam. 1. SCYLLIDE.}

Halve spout-holes and un nictitating membrane, fire gill-openings which staud either all at equal clistances from each other, or the two last are so approximated that the filth appers within the fourth. The last gill-opening is placed over the root of the lorast-fin. All possess a furrow it the corner of the month and an upper lahial cartilage. 'The teeth lave a midlle poir t, aud from one to four ralical trothlets on either sirle. The hrast-fin- are, with few exceptions, broader in proportion to their length thin in the rest of the sharks. The anal-fin stands either before, bancalh, or belind the second back fin. The tail-fin is extusterl longthways, nut forled, trmeated or rumded at the end, with or without at trace of an muder lobe, but provided with a noteh more or less deen near the end on the muler sirle. Notish of this species has a caudal-fin. They atre all clatracterized by a lively colonr or some peenliarity of design in their markings. The gut-valve is spinal. This fumily seems to contain the ege-laping or spawning sharks. The egge are more or less like thos of the rays.

Squali, § 1. Seyllia, Wüll. \& Henle, Wag. Nat. Mist. ii. 1s3↔. Playiost.

Scrllimm, Cur. Reg. An. 2 ed. ii. $1 \times 17$.

Scylliorhinus, Bluine, Bull. Soc. Phil. 121, 1s16. Jour. de Pleys. $263,1816$.

Sryllini, Bometp. Selact. Tab. Anal. 14, 18:3r.

a. Anal-fin neaver the hend than the secumd dorset?

\section{SCYLIIUM.}

The first hack-fin between the lelly-fin and anal: the seeond between the anal and tail-fin. Sprirales elose holind the eyes. The gill-openiugs are placed all at einual distances from each other, the hindmost pair over the hreast-fin. Shout shnt and hlunt ; nostril near the mouth sometimes sending a finrow to the ed ge of the upper. lip. The upper nasal-flap surrounds the mostril in such a mames that for the most part there remains a small romil opening on the vuter side. The nasal-flaps of both sides are separated from each other hs a larger or smiller dilating midhe prece, or they pass across into one another. In some, we find in the middle of the exiemal surfiee a rudimentary heard, which at times projects heynd 
the under edge of the flap. On the under edge of the nostril some have a smaller flap, similar to that which borders the upper edge. The month is bent; the teeth have a middle point, and one or two radical twothlets on each side. In most species the back fins are attached over the claspers. Scales three-pronged. The egrs of this gremus are like those of the rays.

Scyllium. Wïll. 5. Menle, Mag. Nat. Hist. ii. 1839. P'atgiost. Bonap. Selach. Tab. Anal. 11.

Scyllium, sect.* Cur. Rég. An. ii. 386 .

Poroterma, Smith, Proc. Zool. Suc. 1837.

Seylliorhinus, sp', Blaine.

Catulus, sp., S'mith, Proc. Zool. Soe. 1837.

1. Scylliugr Edwardsit. Edwards' Shark.

Scyllium Edwardsii, Cuv. Règ. An. 386. Müll. \& Menle, Plag. p. $4, \mathrm{pl} .1841$.

Greater Cat-fish, Edw. iii. t. $289,1764$.

Squalus pictus, Licht. Verz. der Mouble. Zool. Mus. p. 111.

Catulus Edwardsii, Smith, Proc. Zool. Soc. 1837.

Ha B. - South Africa.

a, b,c. Stuffed. Capc of Good Hope. From Dr. Andrew Smith's collection.

2. Scyllium pictum. Painted Sliark.

Scyllium pictum, Miill. \&. Ilenle, Plag. p. 4, 1841.

H. 1 . - S. Africa.

a. Stuffed?

This appears to be only a variety of Sc. Edwardsii, Cux. Miill. \$. Henle, Ilag. Nacch. p. 189.

3. Scylutu Maculatim. Tiger Shatrk.

Scyllium maculatum, Gray, Hard. Hll. Ind. Zool. i. pl. 98, f. I, 1832. Miill. \&. Ilente, Play. 1. 5, 1811. Rich. Rep. Brit. Assoc. p. 193, 1845 .

Scyllium pardus, Temm. Mus. Leyden.

Scyllium marmoratum, Bem. Life of Raffes, p. 693, 1830.

Catulus marmoratus, Smith, Proc.Žool. Soc. 1837.

Ha b.-Indian Ocean.

a. In spirits. India. Presented by General Ifardwicke,

b. In spirits. From Mr. Argent's collection.

c. In spirits. Presented by the Zoological Society of Jondon.

d. Stuffed. Bramble Bay. Presented by the Earl of Derby. 


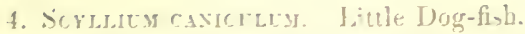

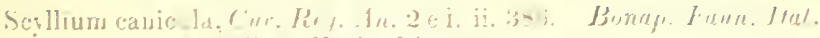

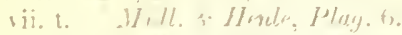

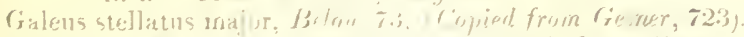

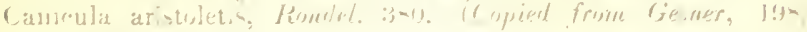

Jolinest. L. ., f. 2.

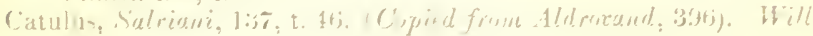
fi. 1.

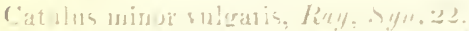

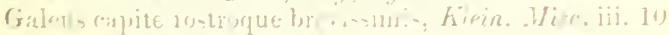

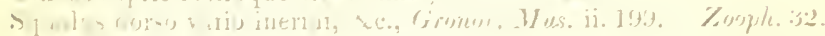
ii. $\ 11$.

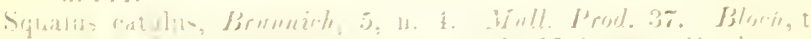

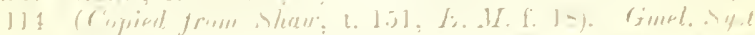

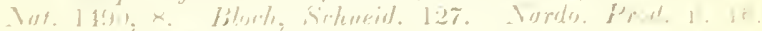
fermec iii. t. j.,.

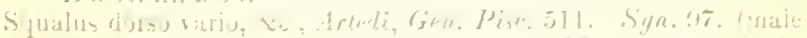

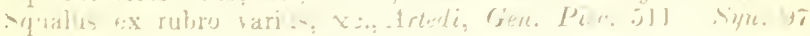
(lemale).

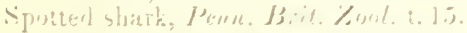

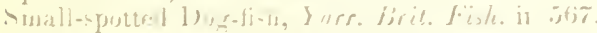

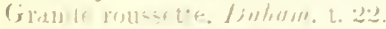

Lid low-sette, Ji,nu s. t..ju.

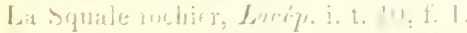

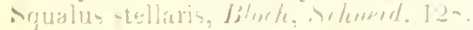

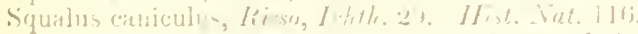

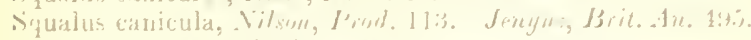

Scvllinu catul is, f\%ming, 1tis.

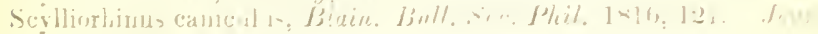

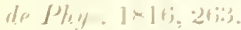

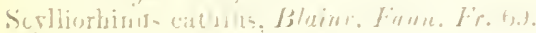

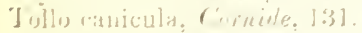

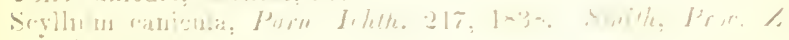
Sien. 1- $=3 \pi$.

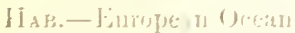

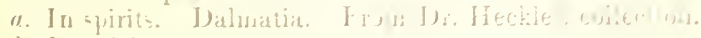

b. In-pirits.

r. Siuffit.

d, r, t. vitufferl. Eingliol $(i, \ldots-1$.

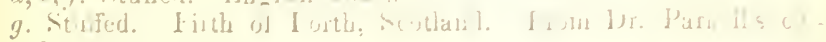
lection.

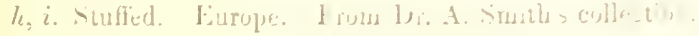


j. Stuffed.

$k-o$. Stuffed. Meditcranean. From Mr. Argent's collection.

p. Stuffed,

q. Stuffed. Mus. Sloane.

\section{Scrllici catulus. Larger Dog-fish.}

Seyllium catulus, Cur. Règ. An. 2 ed. ii. 386.

Galens stellatus minor, Belon. 74.

Canicula saxatilis, Rond. 383. (Copied from Gesner, 199).

Catulus major, Salviani, 138, t. 45. (Copied from Aldrovand, 390 . Irill. B. 4). Jonst. 1. 8, f. 1. Ray, Syn. 22.

Galeus cinereus, Klein, Misc. ii. 10.

Squalus dorso vario mermi, Gronov. Mus. ii. 200. Zool. 32, 11. 145.

La Squile roussette, Lacép. i. t. 9, f. 2.

Squalus canicula, Brunnich, ii. n. 10. Bloch, t. 112. (Copied from Shau, Zool. 152. E. M. f. 17). Bloch, Schneid. 126.

Chat Rochier, Duham. t. 22, f. 2, 3 ? Brousson, 651.

Squalus stellaris, Gmel. Syst. Nat. 1491. Risso, Ichth. 31. Hist. Nat. 116. Jenyns, Brit. An. 496.

Squalus cinereus piunis ventralibus discretis, Artedi, Gen. Pisc. 512. Syn. 97.

Scyllurhinus stellitis, Blainv. T. F.

Rock Dog-fish, Yarr. Brit. Fish. ii. 373.

Scyllium eatulus, Parn. Jchth. 250, 1838.

Scyllimm stellare, Smith, Proc.Zool, Soc. 1837. Bonap. Faun. Ital. vii. t. Flem. Brit. An. 165.

Haв.-Enropean Seas.

«. In spirits. Dalmatia. From Dr. Heck]e's collection.

$b, c$. Stufferl. Mediterranean. From Mr. Argent's collection.

d. Stıffed. Europe. From Dr. A. Smith's collection.

$e$. Stuffed. Sussex. Presented by - Cocks, Esq.

f. Stufferl. Firth of Forth, Scolland. From Dr. Parnell's collection.

g. In spirits. Young.

6. Scrlliva Burgem. Burger's Dog-fish.

Scyllinm Burgeri, Mïll. §. Henle, Plag. 8.

HaB.-Jаран. 


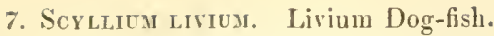

Scyllium liviun, Smith, S. A. Quart. Joum. 1831. Proc. Zool.

Soc. 1837. Mïll. \&. Henle, Play. 8, 1842.

HaB.-Cape of Good Hope.

8. Scyllium capense. Cape Dog-fish.

Scyllium capense, Smith, Proc. Zool. Soc. 1837. Mïll. \&. Henle, Plag. 10, 1841.

HAB.-Indian Ocean.

$a-h$. Stuffed. Cape Seas. From Dr. A. Smith's collection.

9. Scyllium Africanum. African Dog-ásh.

Scyllium Africanum, C'uv. Règ. An. 2 ell. ii. 386. Griff. An. Kingd. x. t. 25. Mïll. \&. Henle, Play. 12. Simith, Illust. Zool. S. Africu. pl. xxv. f. 1, 1849 (female).

Squalus striatus, Forst. MSS.S. iv, 79.

Le galonné, Brouss. Ichth. 659, 9.

Squalus Africauus, Linn. Syst. Nat. 1494, 20. Bloch, Schneid. $1: 29$.

Squalus vittatus, Shaw, Nat. Wise. 346.

Squale ralonié, Lacép. i. 251.

Poroderma Africanum, Smith, Proc. Zool. Soc. 1837.

Scylliorhinus Africinus, Blaine. Bull. Soc. Phil. Jour. 121, 1816.

HAB.-Indian Ocean.

a. In spirits. Cape of Good Hope.

b. Stuffed. Cape Seas. Presented by J. E. Gray, Esq.

c. Stuffed. Cape Seas. Frum Dr. A. Smitl's collection.

d. Stuffed. Cape Seas. (Bleached, taken out of spirits).

10. Scylitum pantherinda. Pantheridine Dogr-fish.

Scyllium pantherinnm, Smith. Miill. S. Menle, Plag. 13, 1841.

Smith, Illust. Zool. S. Afr. pl. xxv. f. 3, 1819 (female).

Scrllium Letpardinum, Mus. Leyden.

Poroderma pautherinum, Smith, Proc. Zool. Soc. 1837.

Hab.-Indian Ocean.

a. Stuffer. (The snecimen desuribed and figured in the 'Illustrations of the Zoology of South Africa'). Cape Seas. From Dr. A. Smith's collection. 
11. Scrllicu rariegatuy. Varicgated Dog-fish. Scyllium variegatum, Smith. Müll. f. Henle, Plag. 14, 1841.

Smith, Illust. Zooi. S. Afr. pl. xxv. f. 2, 1849 (female). Poroderma variegatmm, Simith, Proc. Znol. Soc. 1837.

H.ın.-Indian Ocean.

a. Stuffed. (The specimen deseribed and figured in the "Illustrations of the Zoolngy of South Alrica'). Cape Seas. From Dr. A. Snnith's collection.

\section{PRISTIDURUS.}

This genus has all the characters of seyllimm. It is distinguisherl ly its elongated snout, and ly a row of suball, flat prickles on the upper rim of the tail-fiu, which represent a kind of saw. The tail ats in Scyllimm, but with a trace of an under lobe. The second backfin over the himler part of the anal. The nostrils have a short, skinny, triangular hap. 'The eggs are smooth, as in Scyllium.

Pristidurus, Bumap. Sclac. Tab. Anal. 14, 1838.

Pristiurus, "Bonap." Miell. \& Henle, Mag. Nat. Hist. ii. 1838. Plagiost.

Scyllium, sp. Risso. Bonap. Faun. Ital.

Sicylliorhinus, sp. Blainu. Bull. Soc, Phil. Jour. 121, 1816. Faun. Fr.

Galens, sp., Rafin. Carutt.

\section{Pristidurus melanostomes, Black-month Shark.}

Pristiurus melumostomus, Bonap. Funn. Ital. 15. Müll. Henle, Play. 15.

Squalus catulus, Gunner, Dronth. ii. 216, t. 1,2.

Röll haae, Ascau. t. 3৮.

Galeus melas ouns, Rafin. Carntt. 13.

Sipualus prionurus, ()tto. (onep. 5).

Scyllim Artedi, Risio, Joum. de Phys. t. xii. 242. Hist. n. t. iii.

117, sp. 4. I, the 2 ed. f. 5.

Squalus (Sicyllim) ammulatus, Nils. Prodr. 114.

Black-monthed Dig-fish, Yarr. ii. 375.

Seylliorhinus Delarochianus, Blaimu. Faum. Frr. 74, Sp. 10.

Scylliorhinus melastomess, Bonap. Fasc. vii.

Pristidurus melnostoum, Bunap. Selach. Tab. Anal. 11.

Hab.-Mediterranean and North Seas. 
** Anal behind the second dorsal.

Scyllinm, § 2, Cuv. Règ. An. 2 ed. ii. 386.

\section{HEMISC YLLIUM.}

The nostrils reach within the mouth. The nasal flaps of both sides are dissevered from one another; the outer one is very large, and the inner one possesses a beard. Mouth oblique, transverse, nigh the fore end of the suout. Plaits exist at the coruer of the mouth, and the under ones do not unite in the middle line. Teeth three-lobed. Spiracles large, longitudinal, under the hinder half of the eyes. The gill-openings are all equally distant from each other, the last one over the breast-fiu. Buth back-fins stand over the belly-fin and before the anal; the anal-fin close upon the tail-fin; this has the usual notch at the hinder end, and no under lobe.

Hemiscyllium, Müll. \&. Henle, Mng. Nat. Hist. ii. 183 8. Plagiost. Bonap. Selac. Tab. Anal. ii. 1838.

Scylliorhinus ( $(2)$, Blainv. Bull. Soc. Phil. 1816, 121. Jour. de Phys. 1816, 263.

\section{Hemscyllium oceliatum. Eyed Shark.}

Hemiscyllium ocellatum (Ocellated Shark), Miill. \& IIenle, 16. 1811. Rich. Voy. Erebus \&. Terror, 13, pl. 28, f. \& (scale). Scylliorhinus ocellatus, Blainv. Bull. Soc. Phil. 1816, I21. Squalus oculatus, Banks. (fig.) MS. 56.

L'Cille, Brouss. Hist. de l'Acarl. Roy. des Sci. 660, n. Il, 1780. Squalus ocellatus, Gmel. I494, 21.

Le Squale œille, Lacép. i. 253.

Squalus ocellatus, Shaw, Nat. Wisc. 161. Griff. An. Kingl. t. x. t. 3.

HAB.--Southern Ocean.

$a, b$. In spirits. Sunday Island. Presented by J. B. Jukes, Esq. c. Stuffed. South Sea.

2. Hemiscyllivu trispecdlare. Tri-ocellated Hemiscyilium. Hemiscyllium trispeculare, Rich. Icones Piscium, 5, pl. 1, f. 2. Lond. 1843. Voy. Erebus \& Terror, 43, pl. 28, f. 3-7, 1845 .

Has.-South Sea.

a. In spirits. North-west Coast of Australia. Preseuted by Sir J. Richardson, M.D. 


\section{CHILOSCYLLIUM.}

Snout biunt; the nostrils are cleft up to the month; the nasalflaps of both sides not connected, always carrying a beard. On the outer border of the nostrils there is i consideralie skirt-like flap, which is continued into the upper corner fold of the month. The grenus is characterized by a broad, skimny under-lip, which is separated by a transverse furrow from the outer skin of the throat; the clongated under comer fold of the mouth springs therefrom, and is attached in the middle. Mouth slightly curved. Tecth pointed, with one or two radical tonthlets on each side. Spiracles longitudinal, close behind the eres. A small knob spring forward from the hinder edge of the spout-lole. The fourth and fifth gill-opening are close together. Position of the back-fins, as in Ilemiscrllimm, both are placed before the anal; the foremost belind the belly-fin. The breast and belly-fins are always rounded. The anal and tail-fins are also rounded at the end; the anal without a fore-comer is rounded beneath and pointed behind, and they are close to each other. The under edge of the tail-fin is convex.

Chiloscrllium, Miill. f. Menle, Mrag. Nat. Hist. ii. 1838. Playiost. Orectolobus, Bonap. Selac. Tab. Anal. ii. 1838.

Seylliorhinus (\$ 2), sp., Bluiur. Bull. Soc. Phil. 1816, 321. Jour. de Phys. 161, 263.

Scyllium, sp., Bennett. Gray. Iruhl.

\section{Chilosctulium plagiosrm. Striped Bamboo Shark.}

Chiloscyllim plagiosum, Mïll. \&. Henle, Plag. 17, 1841. Rich.

Rep. Brit. Assoc. 194, 1816. Smilh, Proc. Zool. Soc. Sep. 1837.

Serllium plagiosum, Bennett, Life of Raflles, 693, 1830.

Scyllimm omatum, Gray, Ilard. Ill. t. 98, f. 2, Var. 2, H. 1. H.

Icon. Recres, 252. Hard. Cart. 45, Tas, 3, H. f. H. Russ.

Fish. Coromand. pl. 16.

Orectolohus pla giosum, Bonap.

Orectolobus ornatum, Bonap. Selac. Tab. Anal. ii.

H.в.-Indian Ocean.

a. In spirits. Young. China Seas. Presented by J. R. Reeves, Eisq.

b. Stuffed. China Scas. Prescuted by Gen. Mardwicke.

c. Stuffed. Cape S'eas. From Dr. A. Smith's collection. 
2. Chiloscrleiom Pexctition. Dotted Bamboo Shark.

Chiloserllium puuctitum, Hiill. 5. Henle, Plag. 18.

Scyllium punctatum, fuhlel et r. Hesselt.

H+B.-Java.

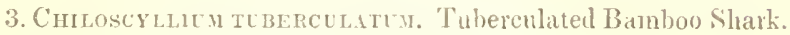
Chiloseyllium tohereulatum, Müll. f. Itenle, Plag. 19

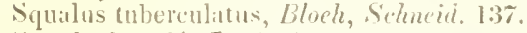

Siquale dentelé, Lacép. i. t. 11, f. 1, 1). 2×1.

Scylliorhinus tuberculitus, Blaine. Bull. Soc. Phil. 1s36, 121.

HAls. - Indiall Ocean,

a. Stuffed. ('ape Seats. From Dr. A. Smith's sollection.

b. In spirits. China. Presented by Sir J. Richardson.

c. In spirits, Joung. From $\mathrm{Mr}$. Frank's collection.

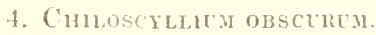

Chiloscyllimn olscurum.

H.s.,Indian Ocean.

a. In spirits. Moluceas, From Mr. Franks eollection.

5. C'mloscrleu griseun. Gray Bamboo Shark.

Chiloscyllium griscum, Müll. j. Henle, Play. 19.

Hab.-India (Jara).

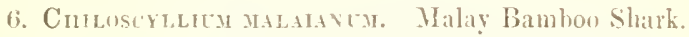

Chiloscyllium malaianum, X., Wiill. 1. Henle, Plny. 20.

Scyllimin malaisianum, Lesson, Duperrey, Tny. 22 lit. Joiss. 1.6. Quoy \&. Grim. Freyc. 192.

HaB.-Gulf of Orfack.

\section{CROSSORIIINT'S.}

liouth large, nearer the end of the snout than in most sharks. Heat broat, flat. The nasal-flap is beset with many skinny shrecis. Tattered appendages hanging to the side of the liead from the nose to the gill-upenings. Cormer folds of the mouth not connected to 
each other beneath. Teeth flat, pointed, with a three-lobed root, the middle lobe being the smallest, rounded, and defined like a toothlet. Spiracles more than usually long, situated beneath and somewhat behind the eyes. Gill-openings all equally far apart from each other, deereasing in size from the first to the last; the last two over the base of the breast-fin. Both back-fins between the belly-fins and antl, the latter elose to the tail-fin.

Crossorhimus, Miill. \&. IImle, May. Nat. Hist. ji. 1838. Plagiost. 21. Bonap. Selac. Tab. Anal. 11, 1838.

Seylliorlinus (\$2), sp., Blaine. Bull. Soc. Phil. 1816, 121. Jour. de Phys. 1816, 263.

\section{Crossorhinus Barbates, Watts' Shark.}

Crossorhinus birbatus, Miill. \&. Henle, Play. 21.

Crossorhinus lobatus, Bonap. Selac. Tab. Anul. 11.

IVatts' Shark, Philip. Voy. 168, 1. 43.

Le barbu, Brouss. 657.

Squalus barbatıs, Linn. Gmel. 1193, 18.

Squalus appendiculatus, Shaw, Nat. Misc. 727.

Le squale barbu, Lacép. i. 247.

Squalus barbatus, Bloch, Seluneid. 128.

Squalus lobatus, Bloch, Schncid. 137.

Seyllium lobatum, Cuv. Rèy. An. 387.

Zee Horekens, Volentyn, Verhandeling, t. 52, A.

Seylliorhinus barbatus, Blaine. Bull. Soc. Phil. 1816, 121.

Hab.-Indian Ocean.

a. Stuffed. New Holland.

$b, c$. Stuffed. Japan. Mus. Leyden.

("Squalus labiatus." Mus. Leyden.

\section{NEBRIUS.}

Suout blunt. Nostrils cleft up to the mouth; a short flap on the inner side, which has a long barbel that hangs over the mouth; also a short flap on the under side of the outer side. Mouth convex. The corner fold of the mouth is divided into an upper and under one by a deep furrow, the inner end of the under one is separated by a more or less deep perpendicular furrow, whence the corner fold of the mouth is rake-like; the pits very deep. Teeth very numerous, up to ten successive rows, a rhomboidal base, with a middle conical point having from two to four blunt, radical toothlets on each side, 
all gradually diminishing in size. The fifth gill-opening is almost concealed within the fourth, both are over the breast-fin. Spiracles rery small, straight, behind the eyes. The first back-fin stands over the belly-fins; the second back-fin sometimes before the anal, sometimes over its beginning. Anal nearer to the tail-fin than the hackfin, but not pressing immediately on the tail-fin. Tail-fiu with a rudiment of an under lobe. The breast-fins are longer than in the other Scyllia.

Nebrius, Rüpp. Chondropt. Abyss. 62.

Scylliorhinus, sp., Blaime. Buill. Soc. Phil. 1816, 121. Jour. de Phys. 1816, 263.

Ginglymostoma, Miull. \&. Henle, Mag. Nat. Hist. ii. 1838. Plagiost. 22. Bonap. Selac. Tab. Anal. 11, 1838.

\section{Nebrius covcolor. Plain Niebrius.}

Ginglymostoma conculor, N., Müll. \&. Henle, Plag. 22.

Nebrius concolor, Rüpp. Chondropt. Abyss. 62, t. 17, f. 2

$\mathrm{H}_{\mathrm{A}}$. - India and the Red Sea.

? a. Stuffed. Young. (In a bad state; the rentral.fins wanting) b. Jaws.

\section{Nebrius cirratu. Bearded Nebrius.}

Gata, Purra. t. 34, f. 2.

Squalus cirrhatus, Linn. Gmel. 1492, 17.

Le barbillon, Lacép. i. 245.

Squalus punctatus, Bloch, S'chneid. 134.

Scyllium eirrhosum, Griff. An. Kingd. x. t. 30 (young)

Squalus argus, Bancraft, $Z$ ool. v. 1835,82 .

Scylliorhinus cirrhatus, Blainv. Bull. Soc. Phil. 121, 1816. Jour. de Phys. 26:3, 1816.

Ginglymostoma cirratum, N., Müll. f. Henle, Plag. 23. Smith, Proc. Zool. Soc. 1837 .

HAB.-Indian and Atlantic Ocean.

a. In spirits. South Seas.

b. Stuffed. West India Islands. From Mr. Scrivener's collection

c. Stuffed. From Dr. A. Simith's collection. 


\section{STEGOSTOMA.}

The mouth is small and entirely trausverse. On the upper and under-jaw the skin forms two flat rolls which support the teeth: these rescmble a tripartite leaflet. The middle part between the nasal-flaps is very much broader than the flaps themselves, and forms a thick, transverse roll above the mouth, forming an upper anterior cover to it: it has a rounded free border in which the fore and hinder surfices unite; the linder one in its usual hidden position is also concare-scooped. The nasal-flaps are reduced to an edgre of skin which binds the middle roll to the sides. A stout barbel-like prolongation of the nasal-flap. No flap on the under edge of the nasal opening. The corner folds of the mouth are short ; the pits deep. The head is much arched and rounded. The opening between the eyelids is very small, transtersely oval, and has sharp elges. The fifth gill-opening is eoncealed in the fourth. The third, fourth, and fifth gill-openings over the breast-fin. The first back-fin stands orer the belly-fin, and reaches directly over the same in front: the seeond back-fin stands between the belly-fins and anal. The anal is close before the tail-fin. The tail-fin is almost equally high throughout, and has the ustal under lobe towards the end, and is very long in proportion to the l,ody.

Stegostoma, Miill. \& Henle, Mag. Nat. Mist, ii. 1838. Playiost. 24. Bonap. Selac. Tab. Anal. 11, 1838.

Scyllium, sp., Rïpp. Chondropt. 1.

\section{Stegustona fascintu. Zehra shark.}

Stegostoma fasciatum, Mïll. \&. Menle, Play. 2t. Bonap. Seloc. Tab. Anal. 11, 1838.

Squalus, Seba, Thesaurus, iii. t. 34, n. 1, p. 105. Gronor. 1hus. i. 82, n. 136. Zooph. 31, 11. 147.

Le tigre, Brouss. 658.

Squalus tigrinus, Gmel. Syst. Nat. 1498, 19. Forst. Zool. Ind. 24, t. 13, f. 2.

Siqualus tongicaudus, Gimel. Syst. Nat. 1496, 24.

Zebra Shark, Shane, Nat. Misc. 434.

Squale tigre, Lacép?. i. 219.

Squalus fasciatus, Bloch, 113. (Copied by Shaw, Gen. Zool. 148 and Encyc. 23). Bloch, Schueid. 130.

Pollee Makum, Russell, 18.

La roussette tigrée, Dict. Sci. n. 33, f. 2. 
Scyllium heptagonum, Rïpp. Chondropt. 1, t. 17, f. 1.

Scylliorhinus tigrinus, Blainv. Bull. Soc. Phil. 121, 1816. Jour. de Phys. 263, 1816.

Hab.-Indian Ocean.

$a-c$. Stufferl.

d. Stuffed. Indian Seas.

$e, f$. Stuffed. Madras Seas. Presented by T. C. Jerdon, Esq.

g. Stuffed. India. Presented by T. E. J. Boileau, Esq.

\section{Fam. 2. SQUALIDE.}

Body elongate, subcylindrical, gradually tapering to the tail. Pectoral-fins moderate lateral. Dorsal-fins, one or two; the first placed between the pectoral and dorsal.fins.

Squali, (§ 2, 3, and 4), Mïll. \&. Henle, Mag. Nat. Hist. ii. 183๙. Plagiost. 28.

\section{Synopsis of Sections and Tribes.}

I. Nictitating membrane distinct; dorsal-fins two; anal distinct.

a. Spiracles none; second dorsal over the anal.

1. Sotaliana.-Teeth flat, sharp-edged, smooth, or serrated.

2. Leptochariana.-Teeth pointed, with lateral denticles.

b. Spiracles distinct.

3. Galieana.-Teeth flat, sharp-edged, smooth, or serrated.

4. Triakiasa.-Teeth pointed, with lateral denticles.

5. Musteliand.-Teeth parement-like.

II. Nictitating membrane none.

a. Anal distinct; dorsal-fins two.

6. Isuriva.-Gill-slits all before the pectorals; second dorsal opposite the anal.

7. Odontasproraxa. - Gill-slits all before the pectorals; second dursal between the rentral and anal.

8. Alopectins. - Last gill-slit over the pectoral; second dorsal opposite the anal. 
9. Heteronostiva. - Last gill-slit orcr the pectoral; second dorsal between the ventral and anal; dorsals spinous.

b. Anal distinct; dorsal-fin one.

10. Huxanchina.

c. Anal none; dorsal-fins two.

11. Acantiana.-Dorsal-fius with a spine in front.

12. Dalatiana.-Dorsal-fins spineless.

1. Nictitating membrane distinct; dorsal-fins two, first between the pectoral and rentral; anal distinct; front branchial-slits before the front edge of the pectoral-fins.

Squali (§ 2), Mrül. \&. Henle, Mag. Nut. Hist. ii. 1838. Plagiost.

A. Spiracles none; second dorsal-fin over the anal.

Squali (§2, a.), Mrïl. \&. Henle, Plag.

\section{Tribe 1. SQUALIANA.}

The head is flat. The suout pointed, blunt or elongate sideways. The nostrils have for the most part a small, three-sided flap to their upper border. The eyelids enclose an acute, oval, or roundish opening; the pupil is perpendicularly oval. The month is boldly convex; the corner fold of the moith small. The teeth in this family are geuerally three-comered, flat, with the cutting-edge entire or serrated, even-sided or unequal. The anal stands directly opposite the second back-fin, or close before it or behind it. The tail has always a slort under lobe, and a slit in its under edge before the obliquely truncated end of the upper lobe. A small threecornered pit may be generally foumd on the upper and under sides of the root of the tail. The intestinal valve is rolled lengthways, not straightways. The scales are small; the skin smooth.

Carcharia, Mrüll. \&. Henle, Plag.

Squalini, Bonap. Selach. Tab. Anal. 10, 1838. 


\section{SQUALUS'.}

Snout flat, more or less rounded, moderately long: the wostrils in the mildle between the mouth and the point of the snont. Labial cartiliges rery small, or wanting. The yelli-bag of the eubryo is connected with a kind of uterine placenta by a curled fold; the oviduct is either smooth or clother with villi.

Squalus, sp., Limn.

Sipualus, Buma\}. Seluc. Tab. Anal. 10, 1×38.

Careharias, Miell. 1. Hente, Mag. Wat. Hist. ii. 1838. Plagiost. 20. Carcharias, part., Cum. Rèy. An. 2 ed. ii. 387.

The form of the teeth divides the genus into tive sub-genera.

1. Teeth in the upper and under-jaw equal, except that there is at single middle tuoth in the upper-jaw, which is wanting in the muder one, cutting with the whole outer efficient point, destitute of serratures. The onter part of the base forms a linut ledge, with or withont a slight indentation. The second back-fin stands straight orer the amal or over the hinder end of the same. Tail-pit distinct ahore and below. Sules small, threc-keeled. The oriduct of the embryo is beset with villi.-Scolrodos.

Scoliodon, Mirll. F. Henle, Mny. Wat. Hist. ii. 3, 1s3s. Plaginst. 28. Bonap. Selac. Tab. Anal. 10, Is3s.

Carcharias, sp., Cux. Rèy. An. :2 ed. ii. 3s\%.

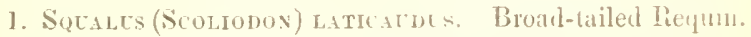
Carcharias (Scoliodon) laticaudus, Miill. Henle, Plag. 2. Is. In nap. Sielac. Tab. Anal. 10.

HAB. -India.

IIus. Paris and Berlin.

2. Squalts (Scoliodox) acotes. Russell's Requill.

Carcharias (Scoliodou) acutus, Riipp. Mull. \$. Menle, Play. 2.4 Riipl. Chondropt. 5, t. 18, f. 4, 1837. Riek. Retp. Brit. Iswo $194,1045$. 
Squalus liussellii, Gray, Illust. Ind. Zool. t. Icon. Reeves, a, 5. Hardw. Icon. ined. B. M. Cart. 50 and 47.

HAn.-Indian Ocean, China. ๘. In spirits. China. Presented by J. R. Reeres, Esq. $b-d$. In spirits. Bengal. Presented by Gen. Hardwicke. $e, f$. In spirits.

\section{Sqtales (Scolionox) Lataxdi. Laland's Requin}

Carcharias (Scoliodon) Lalandii, Valenc. Müll. f. Henle, Play. 30.

Haв.-Rio de Janeiro, Martinique, Guadeloupe.

Hus. Leyden and Paris.

2. The teeth are in all respects as in Scoliodon, within the upper and under-jaw an oblique point, and a ledge on the outer side, without serratures, but they are thicker and less cutting, the point more slender and longer. In the upper-jaw a straight, middle tooth ; two small straight ones in the lower-jaw. The two succeeding teeth on each side hare long hook-like points upon a rounder and more promineut base, which is roundish in its cross section; they are bigger than those which follow. First back-fin close before the belly-fins; the second is over the space between the rentral and anal-fins.-TRigLochis.

Physodon, Mïll. y. Henle, Plag. 30. Valenc. MS.S. Bonap. Selac. Tab. Anal. 10, 1838.

Triglochis, Mill. 1. Henle, May. Nat. Hist. ii. 1838.

1. Squalcs (Triglochis) Mulueri. Muller's Pliysodon. Carcharias (Physodon) Müllexi, Valenc. Miill. \&. Henle, Plag. 30. HAB.-Bengal.

3. The teeth of the upper and under jaw not serrated; the upper teeth straight or slightly inclined ontwards; the under teeth straight, with a proportionally smaller point on a broader base.-APRIon. Aprion, Müll. g. Henle, Plag. 31.

1. Secalus (Apriox) breripixis. Short-fined Aprion. Carcharias (Aprion) brevipinna, N., Müll. g. Henle. Plag. 31. HAB.—Jara. 
2. Seualus acutidens. Sharp-toothed Aprion.

Carcharias (Aprion) acutidens, Riipp. Chondropt. 5, t. Miill. $₫$ Henle, Play. 33.

HaB. - ?

MIus. Frankfort.

3. Squalus (Aprion) isodon.

Carcharias (Aprion) isodon, Valenc. MISS. in Müll. \&. Henle, Plag. 32 .

HAB.

Mus. Paris.

4. The hase of the upper-jaw teeth is serrated, or strongly jagged on the outer side or on both sides. The point of the upper-jaw teeth, and the point and base of the lower-jav teeth wholly smooth, not serrated.-Hy poprion.

Hypoprion, Müll. \& Henle, Plag. 34.

1. Squalus (Hrpoprion) Macloti. Maclot's Hypoprion.

Carcharias (Hypoprion) Macloti, Miill. \& Henle, Plag. 34.

$\mathrm{H}_{\mathrm{AB}}$.-New Guinea.

Mus. Leyden.

2. Squalus (Hypoprion) hejiodon. Half-toothed Hypoprion. Carcharias (Hypoprion) hemiodon, Valenc. Müll. \&. Ilenle, Plag. 35.

HAB - Pondichery.

a. Stuffed. From Mr. Leadbeater's collection.

5. Teeth either in the upper-jaw or in both jaws, and on both sides finely serrated, oblique in direction or straight, three-sided or with a small point on a broad base. Almost always there is a solitary middle tooth in the lower jaw. Oviduct of the embryo smooth, not villous.-CARCHARINUS.

Carcharinus, Blaine. Bull. Soc. Phil. 121, 1816.

Prionodon, Miell. \&. Henle, Plag. 36. 
Carcliarias, Cuv. Ríg. An. 2 ed. ii. 387. Mïll. \&. Menle, Mag. Nat. Hist. ii. 1838.

Squalus, Bonap. Selac. Tab. Anal. 10, 1838.

* The first back-fin standing neaver to the ventrals than to the ireast-fin.

1. Squalus (Camcharines) glaucus. Blue Shark.

Carcharias (Prionodon) glancus, Miill. f. Henle, Plag. 36. Squalus (Carcharias) glaucus, Cun. Règ. An. 2 ed. ii. 38.5. Squalus glancus, Bonap. Faun. Ital. Fase. 27.

Carcharinus glaucus, Bluinv. Bull. Soc. Phil. 121, 1816.

H.в.-Mediterranean and the Ocean.

a. Stuffed. Adult. English Coast.

b. In spirits. (Fotal state).

c. Stuffed. Young.

d. Skeleton.

$e, f$. Two jaws.

2. Sevalus (Carcharints) catdata. New York Shark.

Lamma caudata, De Kay, Nat. Hist. New York, 344, pl. 62, f. 205, pt. Zool. 1842.

Carcharias terræ-novæ? Rich. Faun. Bor. Amer. 289, 1836.

Hab.-New York, Coast of Massachusetts.

** The first back-fin standing close behind the breast-fin.

Isurus, Rafin. Caratt. 12.

3. Socalus (Carcharinus) ceruleus. Small Blue Shark.

Small Blue Shark, Mitch. Trans. Lit. Phil. Soc. i. 487.

Carcharias cæruleus, De Kay, Nat. Hist. New York, 349, pl.61, f. 200,1842 .

H.s.-New York, New Hampshire.

4. Secalus (Caliciarinus) Lamid, The Lamia.

Carcharias (Prionordon) Iamia, Miill. F. IIenle, Plag. 37, pl. ? Squalus glancus, Lacépy. i. t. ix. f. 1, 1798. 
Carcharias glaucus, Rufin. Ind. 45, 1810 . Squalus carcharius, Risso, Ichth. 25, 1810.

Cirrcharius Lania, Risso, Nat. Irist. iii. 119, 1826.

? Carcharius falcipinnus, Lowe, Proe. Zool. Soc. 90, Lomul. 1839.

Carcharias alalonga, Miill. S. Henle, Man. Cut. Mus. Zool. Soc. Lond. No. 703, 705.

HAB.-Mediterranean.

$a, b$. Stuffed. Presented by the Zoological Society of London.

e. Stuffed.

d. Stuffed. Half-grown.

$e$. Skeleton.

$f, g$. Jaws. From Dr. Mantell's collection.

$h-m$. Jaws.

n. Stuffed. Young.

5. Sounus (Carciarinus) Milberti. Milbert's Shart. Carcharias Prionodon, Milbertii, Valenc. Müll. . IIenle, 38. $\mathrm{HAB}$. ? Mus. Paris.

a. Stuffed. India. Presented by T. E. J. Boileau, Esq.

6. SQunlus (Carcharinus) gavgeticus. Gangetic Shark. Carcharias (Prionorlon) gangeticus, N., Müll. F. Henle, Plag. 39. HaB.-Indian Ocean.

a. Stuffed. Calcutta. Presented by - Blyth, Esq.

7. Squalus (Carcharinus) glypirs. Müller's Shark. Carcharias (Prionodon) glyphis, N., Müll. S. Henle, Play. 40. HAB. ? Mus. Berlin.

8. Sevalus (Carcharixus) Aubonnexsis. Amboina Shark. Carcharias (Prionodon) Amboinensis, N., Miell. f. Ilenle, Plag. 41. HaB.-Amboina. Mus. Leyden.

9. Squalus (Carcharinus) oxyrhyncuus. Sharp-nosed Isurus. Carcharias (Prionodon) oxyrbynchus, N., Miell. f. Henle, Plag. 41. Isurus oxyrhinchus, Rafin. Caratt. 12, pl. xiii. f. 1, 1810. (fide Miller).

$\mathrm{H}_{\mathrm{AB}}$ - - Surinam.

a. Stuffed. West Indies, From Mr. Scrivener's collection. 
10. Squates (Chrchirixcs) latcas. Leucas Shatk.

Carcharias (Priouodon) leucas, I'alenc. Mïll. f. Ilenle, Plag. 42. Haв.-IVest Indies. Mus. Paris.

*** The first back-fin in the middle between the pectorals and rentrals, or nearer the former.

11. Squalus (Carchariver) melanopterus. Black-finned Shark. Carcharias (Prionodon) melanopterus, Quoy \&. Gaim. Miill. \&. Henle, Plag. 43. Rich. Rep. Brit. Assoc. 194, 1845.

Squalus carcharias min, Forsk. Descr. 30.

Squalus requin, Lacépr. v. 169, t. 8, f. 1 .

Carcharias melanopterus, Quoy 5. Gaim. Nreyc. Voy. Zool. pl. 43, f. 1,2 .

Squalus ustus, Dum. Cuv. Règ. An. 2 ed. ii. 388.

Squalus Spallanzanii, Lesueur, Phil. Journ. ii. pl. 2, 351.

Carcharias melanopterus, Bennett, Life of Rafles, 693. Rüpp. Chondropt. 3.

Carcharhinus ustus, Blainv. Bull. Soc. Phil. ii. 121.

Hab.-Red Sea, Java, Australia, Timor.

a. Stuffed. Cape Seas. From Dr. A. Smith's collection.

b. In spirits. Molnceas, From Mr. Frank's collection.

$c-f$. In spirits. (Fœtal state). Port Arthur. Presented by Sir J. Richardson.

g. In spirits. Young. China. Presented by Sir J. Richardson.

h. In spirits. Young. South Australia.

i. In spinits. Young. South Australia. Presented by Sir J Richardsou.

12. Squales (Carcharines) aldimarginates. White-edged Shark. Carcharias (Prionodon) albimarginatus, Riipp. Chondropt. 4, t. 18, f. 1. Hiill. d. Ilenle, Play. 44.

Hıв.-Red Sea. Mus. Frankfurt.

13. Squalus (Carcharixus) Mrou. Maon Shark.

Carcharias (Prionodon) Maon, N., Miill. f. Ilenle, Play. 4.

Squalus Maou, Less. Dup. Voy. 91.

HAB.-Mer de l'Archipel des Pomotous. 
14. Squalus (Carcharinds) Sorrah. Sorrah Shark. Carcharias (Prionodon) Sorrah, Valenc. MSS. Miill. \& Henle, Plag. 45.

\section{Har.-Indian Ocean.}

a. In spirits. Singapore. From Mr. Argent's collection.

15. Squalus (Carcharinus) obscurus. Dusky Shark. Carcharias (Prionodon) obscurus, N., Mïll. \&. Henle, Plag. 46. Squalus obscurus, Lesueur, Phil. Journ. i. 223, t. 9. Act. Nat Sci. i. 223, f. 201. De Kay, Nat. IIist. of New York, 350, pl. 61, f. 201,1842 .

Hab.-North America.

? a. Stuffed. (OId collection).

16. Squalus (Carcharinus) Henler. Henle's Shark. Carcharias (Prionodon) Henlei, Valenc. MSS. Mäll. \& Henle, Plag. 46.

? Carcharias fissidens, Benuett, Proc. Zool. Soe. Lond. 1830-31, 148.

H.b.-Cayenne. Mus. Paris.

17. Soualus (Carcharinus) Menisorrah. Menisorrah Shark. Carcharias (Prionodon) Menisorrah, Valenc. MSS. Miill. \& Henle, Plag. 46.

HaB.-Indian Ocean.

a. Stuffed. Moluccas. From Mr. Franks' collection.

18. Seualus (Carcharinus) Falcifonnis. Scythe-shaped Shark. Carcharias (Prionodon) falciformis, Bibron, MSS. Mïll. S. Henle, Plag. 47.

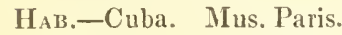

19. Squalus (Carcharinus) Dussumeri. Dissumier's Shark. Carcharias (Prionodon) Dussumieri, Valenc. Miill. \& Henle, Plag.

47. Rich. Rep. Brit. Assoc. 194, 1845.

Hab.-China, Bombay, Pondicherry. Mus. Paris and Berlin. 
20. Socalus (Carcharixes) Temmixcir. Temminck's Shark. Carcharias (Prionodon) Temminckii, N., Mïll. \&. IIenle, Plag. 48. HAB.-India.

a. Stuffed. Calcutta. From Mr. Bartlett's collcction.

21. Socales (Carcharivus) limbatus. Margined Shark. Carcharias (Prionodon) limbatus, Talenc. Müll. \& Ilenle, Plug. 49.

HaB.-Indian Ocean.

? a. Stuffed. India. Presented by T. E. J. Builcau, Esq.

\section{SPHYRNIAS.}

The fore part of the hear is broad, flat, and elongate on the sides, with the nostrils situated on the fore-border of it. The eyes on the lateral ends. The nasil-thap is a small, three-sided lappet on the inner edge of the nostril. Small labial cartilages. Teeth equal above and below, a flat pramid inelined ontwards with a ledge on the outer side of the base, entire or serrated. A middle tooth in both jaws. The first back-fin stands nigher to the pectorals than to the belly-fin; the second is smaller than the first, and stands over the anal. Tail-pits distinct. The oriduct of the embryo is set with villi. The yelk-bag is conneeted to the walls of the uterus.

Sphyrniats, Rafin. Anal. Nat. 93, 1815. (No character or type). Sphyma, "Rafinesque," Inelex, 46. Cuv. Règ. An. 2 eul. ii. 393. Huill. \&. Henle, Plag. Bmap. Selach. Tab. Anal. 10, 1838.

Zygæna, Cuv. Rèy. An. 2 ed. ii. 393. Miill. \&- Henle, Mag. Nat. Hist. ii. 1838 .

Cestrorhinus, Blainv. Bull. Soc. Phil. Jour. 121, 1816. Jour. de Phys. 263, 1816.

1. Sphirxias Zrgena. Hammer-headed Shark.

Sphyrua Zygæna, "Rufu." Miill. \&. Henle, Plag.51. Rich. Rep. Brit. Assoc. 194, 1845.

Zygxna, Rond. 389. (Copied from Gesner, 82).

Libella, Belon. 61. Salriani, 121, t. 40. (Copied from Aldrovand, 408). Jonston, 1. 7, f. 8. Willoughby, B. 1. Ruysch. Theatr. t. 7, f. 8 . 
Zsgmna, s. Lihella, Jacob, .Hus. 16, t. 7, f. 5.

Jochfiseh, Valentine, Mus. t. 32, f. 5.

Zygæna, Ray, 20, 7. Mus. Besler, t. 15, f. 1. Linn. Mus. Ad. Frid. 52.

Cestracion fronte arcus figura, Klcin, Misc. iii 13, n. 1.

Stampella, Scilla, t. 28, f. 2 .

Piscis libella, Bomman. Mus. Firch. 1. 37, f. 20.

Zygène, Duhamel, sect. 9, p. 21, f. 3, 8. Duter. Hist. Wilt. ii 207.

Squalus capite latissimo, transrerse, malei instar, Gromon. Hhes. i.

(i3, 139. Zouph. 146. Artedi, Gen. Pisc. 447. Symon. 46, 7.

Le Martean, Brousson.n. 11.

Squalus Zygæua, Brïnnich, 4, 11. s. Forsh. Descript. 18. Bloch, 117. 131. Lim. Gm. 1494, n. 5. Mitch. Trans. New York, i. 482 .

Martillo de Mar, Bru de Ramom.

Cornuda, Purra. Lim. 32.

Squalus, No. 4, capite transverso mallei instar, Brounc, Jam. 45.s.

Le Squale Martean, Lacép. i. 257.

Le Squale pantouflier, Lacép. i. 260, pl. vii. f. ?3.

Koma Sorra, Russell, t, xii.

Hammer-headed Shark, Shan, Gom. Zool. 354, pl. 154.

Zygæna malleus, Risso, Ichth. 31. IIist. Nat. jii. 125. Valene. Mem. du Mus. t. 9, p. 223, pl. 11, f. 1, a, b. Ayassiz. t. E, t. 7. (teeth). Farr. Brit. Fish. 504, 1841. De Kity, Nut. Ifist. of Nen Yirk, 362, pl. 6i2, f. 204.

Sphyrna Zyexna, Rafix. Ind. 46. Bonap. Faum. Ital. Fase, 27. Rich. Rep. Brit. Assoc. 194, 1845.

Zygene Marteau, Dict. Sici. Nat. t. 32.

Zygæna Lewisii, Griff'. Au. Kingl. t. 50.

H.B.-Mediterranean, Indian Ocean and Atlantic.

a. In spirits. Mediterranean.

b. In spirits. Sumatra. From Mr. Frank's rollection

c. Iu spirits. Demerara. Presented hy Sir R. Sehomburgh.

d, e. In spirits. (Fœtal state).

f. Head.

y. Stuffed.

h. Stufferl.

i. Stuffed.

j. Stuffed. Mediterranean. 
2. Siphynuias Tudes. The Tudes.

Sphyrna Tudes, Miill. \&. Menle, Plag. 53.

Zyganat tudes, Valene. Mem. du Mus. 9, t. 11, f. 3. Agass, iii. t.

E, f. 8. (tecth). Yurr. Birit. Fish. 2 ed.507, f. 1, 1841.

II B.

3. Spuyrias tiburo. Heart-headed Shark.

Splivrna tilumo, Miell. \& Henle, Play. 53.

'Tiburonis Splurma minor, Maregr. Pise. Hist. Wat. 181. Cop.

Willoughby, t. B, 9, f. 4. Ruysch. Theutr. t. 39, f. 7.

Cucuri Brasiliensibus, Ray, Ichth. 20, 11. 4.

Zygana affinis capite triangulo, Ray, Ichth. n. 8.

Galens capite in hyperbolam desinente, Klein, Misc. iii. 12.

Cestracion cordisfigma, Klein, . Kiss. iii. 13, ı. 2, f. 3, 4.

Le pautouflier, Brouss. 662.

Squalus tiburo, Lim. Gm. 1495, 16. Shaw, Nat. Nise. 229. Bloch, Schneid. 131.

Heart-leuded Shark, Shur, Gen. Zool. 154.

Zygæna tiburo, Valenc. Mcm. du Mus. ix. 12, f. 2. Aguss. iii. t. E, f. 9. (teeth).

Arrow-headed Shark, Penn. Supp. 105.

Zy gænа tiburo, Yar. Brit. Fish. 2 ed. 507, f. 2, 1841.

Cestrorhinus tiburio, Bluinr. Bull. Soc. Phil. 121, 1816.

HAB.-Brazil.

a. In spirits. China. Presented by Sir J. Richardson.

b. In spirits. American Seas.

4. Spinysias Blocun. Broad-headed Shark.

Sphyrna Blochii, Mïll. f. Hcule, Plag. 5́1.

Zygæna Blochii, Talenc. Mem. du Hus. ix. t. p. 11, f. 2. Benn.

Life of Ruffles, 693. Hardw. Icon. Ined. 53-58.

Zygæna liticeps, Cantor, Yarr. Supp. 65, 508, pl. 3. (young).

Z. Blochi, pl. 4. Z. laticeps (adnlt), 2 ed. 1841 .

H.B.-Irdian Ocean.

a. In spirits (hcad). India. Presented by Gen. Hardwicke.

b. In spirits. Siugapore. From Mr. Argent's collection.

r. Stuffed. India.

d. Stuffed. From Dr. A. Smith's collection.

r. Sinffed. Young. 
5. Sphyrias Mokarran. The Mokarran.

Sphyrna Mokarran, Miill. \&. Henle, Plag. 53.

Zygæna Mokarian, Rïpp. Chondropt. 5, t. 17, f. 3.

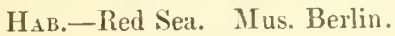

2. Head flat. Snout sharp or blunt. The nasal-flap is broad, or it is prolonged into a barbel. Eye-openings longitudinal. Comer folds of the mouth very small. The teeth as in Scyllia, small, numerous, with a long, middle prong, and one or two radical notches on either side of the base, similar in the upper and under-jaws. The second back-fin and anal stand opposite to one anotlier, or nearly so. The tail-fin is as in Carcharias, or as in those Scyllia in which the under lobe is scarcely pronounced. Tail-pits existing or wanting. Scales three-pointed, five to seren deep.- LeptochsPIANA.

Triænodontes, Miill. \&. Henle, Plag. 5.

Triænodontini, Bonap. Selac. Tab. Anal. 10.

\section{LEPTOCHARIAS.}

Leptocharias, A. Smith. Miill. \&. Menle, Mag. Nat. Hist. ii. 13, 14, 1838.

Carcharias, sp., Riipp.

Triænodon, Miill. \& Henle, Mag. Nat. Hist. ii. 1838. Plagiost. 5.

1. Leptuchariss obesus. Red Sea Leptocharias.

Carcharias obesus, Riipp. Chondropt. 4, t. 18, f. 2.

Triænodon obesus, Miill. \&. Henle, Play. 55.

$\mathrm{H}_{\mathrm{AB} .}$-Irdian Ocean, Red Sea. Mus. Berlin.

2. Leptocharias Smithil. Smitl's Leptocharias.

Leptocharias Smithii, Smith, May. Nat. Hist. N. S. ii. n. 13, 14, 1838.

HAB.-Southern Ocean.

a. Stuffed. Southern Ocean. Cabenda Bay. (The specimen described and figured by Müller and Henle). 
B. With nictitating membranes and spiracles; the last or the taco last gill-openings over the jrectmal-fins.

Squali (§2, B), Mill. ₹. Menle, Plag. 37.

3. Head flat. Snout pointed or blunt. Nostrils, openings between the evelids. Mouth, and its eorner folds as in the Carchariæ; but they all possess small lip-cartilages. The spiracles are small, longitudinal, or round. Teeth in both jaws alike, flat, with euttingedges, a puint inelined obliquely outwards, and a ledge on the outer border; the edges are either wholly without serratures, or they are serrated on the outer side only, or on both sides. The anal stands close before, behind or opposite to the second back-fin. The upper lobe of the tail-fin has one or two notches before its end. The tailpit exists or is wanting. The gut-valve is either screw-formed or rolled lengthways. Scales small, three-keeled, with a middle point. -Galeina.

Galei, Müll. \& Menle, Plag. 5.

Squalini, part, Bonap. Selac. Tab. Anal. 10, 1838.

\section{GALEUS.}

The longest spiracles about half the length of the eye-openings behind the eyes. The pupil forms an angle beneath, and is round abore. The teeth have an inner smooth edge and an onter serrated one, which is set off from the upriglit smooth point of the tooth: in some tceth the inner edge exhihits a trace of a fine serrature. The front teeth are straight, jagged on both sides of the base, and no smaller than the side teeth. Tail-pit wanting. The upper lohe of the tail-fin has a notch. Gut-valve screw-formed.

Galeus, Cun. Règ. An. 2 ed. ji. 3s9. Bonap. Seluc. Tab. Anal. 10, 1838. Miull. \& Henle, Mag. Nat. Hist. ii. 1838. Plagiost. 37. Flem. Brit. An. 165.

Galcorhimus, sp., Blaim. Bull. Soc. Phil. Jour. 121, 1816. Jour. de Phys. 2fi3, 1816.

1. Galeus canis. The Tope.

Galeus canis, Miill. \&. Henle, Plag. 37. Rond. 37\%. (Copied from Gesner, 197). Bonap. viii. 
Canis galeus, Salviani, 130, t. 41. (Copied from Jonston, \&, f. 4). Hilloxyhby, 13. 6. Ruysch, Theatr. t. 8, f. 4.

Galeus piscis, Churkon, Onom. 209.

Squalus galeus, Brmmich, 4, 1. 9. Limm. Gm. 1492, 7. Bloch, Schneid. 128. Risso, Ichth. 32. Nils. Prod. 115. Jenyns, 501. Blainv. Faun. Fr. \$̇.

Le Milandie, Bronsson, 65:3.

Squalus narilns ori vichis, foraminilus exiguis ad oculos, Art. Gen. Pisc. 509) \$ Sim. 97.

Le Squale Milandre, Lacép. i. 237.

Squalus (Galens) (Galeus, Cur. Rig. An. 2 ed. ii. 3*9.

Milandre, Duham. 20, f. 1, 2. Niet. Sci. Nat. Poiss. pl. 2!.

Carcharias gileus, Risso, Hist. Nat. iii. 121.

Galens vulgaris, Flem. 165. Jarmell, 390. Parn. Ichth. Firth of Forth, ls:3s.

Galeorhinns galens, Blainv. Bull. Soc. Phil. 121, 1836.

HaB.-Atlantic and Indian Ocean.

a. Stuffed. Enerlislı Coast.

$b, c$. Sunffed. From the Antaretic Expedition. Presented by the Admiralty.

d. Stuflecl. Indian Seas. From Dr. A. Smith's collection.

e. Stuffed. Cilpe of Good Hope. From I)r. A. Smith's collection.

f. In spirits. Firth of Forth. From Dr. Leach's collection.

2. Galeus Japanicts. Jajar 'Tape.

Galeus Japrnicns, Mill. S. Temle, Plag. Ds.

Haв.-Japan. Mus. Leyden.

\section{GALIOCERDO.}

Spiracles very small, about half the length of the eye-openimgs behind the eyes. Pupils as in Gilens. Conner pits of the momth, and labial cartilages indistinet. Teeth cutting, denticulated withiu and withont. The point looks outwardiy; the outer edge passes into a ledge muder an angle on the onter side of the tooth, and coarsely jagged. A single middle tooth as well in the upper as in the under-jaw, whose point is bent on one side. The npper lobe of the tail-fin is long, and ends in a point: its muder border has hefore its hinder tnd two successive notches, whereof the second weents at the end of the spine. Tail-pit above and helow. (int-ralve rolled lengthways.

Gatencerlo, Mill. f. IIenle, May. Nat. Hist. ii. 1838. Plogiost. 59. Bonup. Sielac. Tab. Ancel. I0, 1sist. 
1. Galeocendo tigninus. Tiger Tope.

Galeocerdo tigrinus, Mïll. \&. Henle, Play. 59.

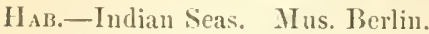

a. Sunfed. Indian Seas. P'resented by T. C. Jerdon, Esq

2. Galeocerdo arctices. Arctic Tope.

Galeocerdo areticus, Müll. \&. Henle, Plag. 60. Bonap. Sclar. Tab. Anal. 10, 1838.

Canis Carcharias, sp. 2, Itérissant, Ac. de Sci. 158, pl. 19, 1749. Lacép. i. t. 8, f. 2 (teeth).

Squalus Carcharias, Blake, Dent. Format. f. Struct. t. 6, f. 5 (tecth). Galeus areticus, Faber, 17.

Squalus areticus, Nils. Prod. 115.

Galens cepedianus, Agassiz, Feuill. 71, t. E, f. 5, 6 (teeth).

Gilleus, Owen, Odontol. t. 28, f. 9 (teeth).

$H_{\text {a }}$.-North Sea Islands, Faruë, Norway.

$a, b$. Jaws. From the Chatham Musemin.

c. Jaws. Presented by Mr. H. S. Hall.

\section{LONODON.}

Pupil round. Teeth with an oblique edge without serratures, and a ledge on the outer side of the base also entire, alike in both jaws: in the upper-jaw a midlle tooth; in the under-jaw none. Spiracles small, behind, and near the eyes. Tail-pit above and below. Upper lobe of the tail-fin only once notched. Gut-valve?

Loxodon, Mïll. \&. Henle, Mag. Nat. Hist. ii. 1838. Plagiost.61.

(not F. Curier). Bonap. Selac. Tab. Anal. 10, 1838.

1. Loxodos nucromixus. Large-bealied Loxodon.

Losodon macrorbinus, Mïll. 5. Henle, Plag. 61.

Haв. —? Mus. Berlin.

\section{THAIAASORUINUS.}

Pupil perpendicularly oval. Nasal-flap very short. Teeth threecomered, without a lerlge, serrated. Spiracles tolerably large. Tailfin, as in Careharias, only once notched. Tail-pit conspicuons above and below. Gut-valve rolled lengthways. 
Thalassorhinus, "Pall. MSS." Miill. \&. Henle, Plag. Bonap.

Selac. Tab. Anal. 10, 1838.

Galeus, sp., Valenc. Ann. Sci. Nat. 1835.

Galeorhinus, sp., Blainv. Bull. Soc. Phil. 121, 1816.

\section{Thaldssorhinus Rondeletil. Rondelet's Shark.}

Carcharias Rondeletii, Risso, Ichth. 27. Hist. Nat. iii. 120.

Galeus thalassinns, Valenc. Leçons d'Anat. Comp. de G. Cuv. t. 4, p. 2. Revu par G. L. Dumenoh, 401, Paris, 1835. Ann. Sci.

Nat. 2 Série, iii. $274,18: 35$.

Galeorhinus Rondeletii, Bluimv. Bull. Soc. Phil. 121, 1816. Thalassorhinus vulpecula, Müll. \& Henlc, Play. 62. Bonup. Selac. Tab. Anal. 10, 1838.

$\mathrm{H}_{\mathrm{AB} .-\mathrm{M}}$ - Mediterranean aud Ocean.

2. Thalassorhinus platrmunchus. Flat-nosed Shark.

Thalassorhinus platyrhynchus, N., Miill. \&. Henle, Plag. 63. Squalus platyrhynchus, Walbaum, Nat. Fr. v. 381. Art. Gen. 521 $\mathrm{H}_{\mathrm{AB}}$.

4. Head flat. Snout blunt. Nasal-flap broad, and modcrately long. Corner pits of the mouth and labial cartilages large. The eyelids enclose a long opening. Spiracles of medium size. Teeth as in Scyllia, a long middle prong, with many lateral notches on the base. "In form, the fins resemble those of the true Scyllia. The under lobe of the tail-fin is abortive, and the tail-pits are rvanting. Scales three-keeled and three-pronged.-Thгкinsi.

Scylliodontes, Miill. \&. Heule, Plag. 63.

\section{TRIAKIS.}

The character of Tribe.

'Triakis, Müll. \&. Henle, Mag. Nat. Hist. ii. 1838. Plag. 63.

1. Triakis scyluicm. The Triakis.

Triakis scyllium, Mïll. to. Henle, Plag. 63.

HAB.-Japan. 
2. Trtakis Califorxici. Californian Triakis.

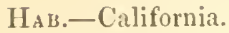

a-e. In spirits. Fœtal state. California.

5. Spiracles large. Long eye-openings. The nictitating membrane is puffed, and looks like a doubling of the under eyelid. Teeth pavement-like, flat, without point or cutting-edges as in the teeth of the rays. Cartilages at the eorner of the mouth, with deep pits there. On the upper border of the nostril a three-sided lobe of skin with a rounded point, whose base girdles three-fourths of the border; on the ontside thereof a short, blunt lobelet. The first back-fin nearly in the midrlle, between the breast and belly-fins. Tail-fin short. Tail-pits indistinet. Gut-ralve screw-formed.-Musteliais. Musteli, Mïll. f. Henle, Plag. 64.

Iustelini, Bonap. Selac. Tab. Anal. 10, 1838.

\section{MUSTELUS.}

Mustelus, Cux. Règ. An. 2 ed. ii. 339. Bonap. Selac. Tab. Anal. 10, 183s. Miill. f. Henle, Mag. Nat. Hist. ii. 1838. Plagiost. Galeus, sp., Rafin.

Galeorlinus, sp., Blaint. Bull. Soc. Phil. 121, 1816. Jour. de Phys. 263, 1816.

1. Mestelus vulgaris. The Hound-fish.

Mustelns vulgaris, Miill. \&. Henle, Plag. 64. Rich. Rep. Brit. Assoc. 195, $18+5$.

Galeus hinnulus, Belon. 72.

Galeus lævis, Rond. 375. (Copied from Gesner, 717). Gesner, 726. (Copied from Aldrovand, 392). Kilein, Misc. Pisc. iii. 9, t. 1, f. 7 .

Galens asterias, Rond. 37\%. (Copied from Gesner). Aldrot. 393. Mus. Worm. 272.

Mustelus lævis, Salriani, 137, t. 44. (Copied from Willoughby), B.5. Jonston, viii. 6. Ruysch, Theatr. t. viii. f. 6. Flem. 166.

Mustelus stellaris, Salriani, 138.

Galeus asterias s. stellatus, Jonst. t. viii. f. 8. Ruysch, Theatr. t. viii. f. 8 . 
Squalus dentibus obtusis s. granulosis, Gron. Mus. i. 135. Artedi, Gen. Pisc. 505.

Smooth Shark, Penn. t. xvi. (Copied from Encycl. Méth, F. 21). L'èmissole, Brouss. 655.

Squalıs mustelıs, Miill. Prod. 38, n. 317. Linn. Gm. 1492. Bloch, Schneid. 128. Risso, Ichth. 33. Jenyns, 502.

Pintarroja, Comide, 133.

Squale émissole, Lacép. i. 242.

Emissole commune, Dict. Sci. Nat. xxxii. 2.

Mustelus lævis et stellatus, Risso, Hist. Nat. iii. 126.

Emissole commune und Emissole tachetée de blanch, Cuv. Rég. An. 2 ed. ii. 390.

Mustelus plebeius, Bonap. Fam. Ital. viii. t.

Mustelus equestris, Bonap. Faun. Ital. viii. t.

Smooth Hound, Yarr. ii. 393.

Squalus mustelus hinnulus, Blainv. Famn. Fr. 83, 84.

Squalus mustelus lævis, Blainr. Fann. Fr. 83, 84.

Galeorhinus mustelus, Blaine. Bull. Soc. Phil. 121, 1816.

Hab.-Coast of Cormwall.

a. Stuffed,

$b, c, d$. Stuffed. From the Antarctic Expedition. Presented by the Admiralty.

e. Stuffed. Mediterranean.

$f, g, h$. Stuffed. Cape Seas. From Dr. A. Smith's collection.

i. English Coast.

j. In spirits. Berwick-upon-Tweed. Presented by Dr. Johnston.

$k$. In spirits. New Zealand. Presented by Sir J. Richardson, MI.D.

2. Mustelus Levis. Smooth Hound-fish.

Nustelus læris, Mïll. f. Henle, Play. Nacht. 190.

$\mathrm{HAB}$.

3. Mustelus punctulatus. Gray Hound-fish.

Mustelus punctulatus, Risso. Miill. S. Henle, Plag. 66. Risso, Hist. Nat. iii. 127.

Squalus canis, Mitch. Trans, Lit. Phil. Soc. i. 486.

IIustelus canis, De Kay, Nat. IIist. of New York, 355, pl. 64, f. 209 , pt. 1. Zool. 1842 .

Has.-Mediterranean, Cape, Ocean. 
4. Mestelus megalopterus, Large-finned Hound-fish.

Mustelus megalopterus, Snzith, Illustr. Afr. Zool. pl. 11 (male)), 1839 .

H.iв.-Cape Seas,

II. Nictitating membranes none; spiracles distinct, often small.

A. Dorsal-fins tuen; anal distinct.

squali ( $(2, c)$, Miull. f. Henle, Mug. Nat. Hist. ii. 1838. Plagiost. 67.

6. The gill-openings are large, and all lie before the breast-fins. The eye-openings roundish. The second back-fin and the anal roundish, of equal size, opposite to one another. Distinct tail-pits. Crescentic tail-fin. A keel on each side of the tail. Spiracles very small. Gut-valve screw-formed.-Isuriva.

Lamnoidia, Mïll. \&. Henle, Mag. Nat. Hist. ii. 1838. Plagiost. 67. Lamnæ, Miill. f. Henle, Plag. 67.

Lamuini, Bonap. Selae. Tab. Anal. 9, 1838.

\section{ISURUS.}

Snout three-sided, pyramidal, pointed. Nasal-flap short, threesided. Spiracles very small, far behind the eyes. Teeth flat, not serrated, three-sided, with a short-pointed denticle on each side of the base of the older ones, which is sometimes doubled. The jaw end of the teeth is deeply concare towards the jaw. No middle teeth, but a space in their stead in the upper and under-jaw. The two front teeth of the upper-jaw are followed on either side by one or more smaller ones. The skin is smooth. Scales very small.

Isurus, Rafin. Caratt.

Lamia, Grecks. Risso, Ichth. Nice. (not Fab.).

Lamna, Cur. Règ. An. 2 ed. ii. 388, 1817. Mrill. \&. Henle, Mag.

Nat. Irist. ii. 1838. Plaqiost. 67.

Carcharhinus, sp., Blaim. Bull. Soc. Phil. 121, 1816.

1. Isures corvubices. The Porbeagle.

Canis carcharias, Aldror. 383.

Porbeagle, Borl. Cormu. 265, t. 26, f. 4. Yarr. Brit. Fish. 384. 
Squalus monensis, Penn. iii. t. \%. Jenyns, Brit. An. 501. Shau, Gen. Zool. v. pt. 2, p. 350.

Touille-bœuf ou Loutre de Mer, Drhamel, pl. 20, f. 1.

Le Nez, Bronss. 66 \% , 16. Lacép. i. t. 11, f. 3.

Squalus glaneus, Haa-Maer, Olar. Isl. 382, t. 6. Strïm. Norske I'idensk. Selsk. Sir.t. 2, 335.

Squalus cormuhicus, Limm. Gm. 1497, 25. Goodenough, Limn. Soce. iii. 80, t. 15. Bloch, Sichneid. 132. Gmel. Siyst. Nat. Donot. v. 108. Nils. Prod. 116. Jenuns, Brit. An.501. Fries 1. Eekst. Skand. Fisk, Heft. v. t. 30 .

Haa-brant, Asectn.31.

Carcharhinus monensis, Bluine. Bull. Soc. Phil. 121, 1816.

Carcharhinus cornubicus, Blainr. Bull. Soe. Phil. 121, [\$16,

Squalus selanonus, Leach, Heru. Mtem. t. ii. 6t, t. ii. f. 2.

Lamue-nez, Dict. Sci. Nat. t. 2i, fi. 1.

Lamia comubiens, Risso, Hist. Nat. iii. 124.

Lamna cornubica, Flem. 16׳. Bumap. Fann. Ital.61. Agassiz, t.

G, f. 1 (teeth). Mïll. \&. Honle, Plag. 67.

Squalus (Lamua) cornubicus, ('ur. Ríy. An. 2 ed. ii. 389.

Beaumaris Shark, Yarr. Brit. Fish. 3\%.

Isurus uxyrhyuchus, Rafin. Caratt. 12, 1. 13, f. 1.

Squalus (Lainua) monensis, ('ur. Rèy. An. 2 ed. ii. 389.

HAB.-Allantic Ocean.

a. Stuffed. Adult male. Euglish Coast.

b. Stuffed. Adult feurale. English Coast.

c, d. Stuffed. Young.

$e, f$. Jaws.

\section{OXYRHINA.}

Snout, spiracles, and fins as in Isurus. Teeth very thick, narrow, and long, nail-shaped, wholly without basal denticulations; the fore ones rery long, and bent in a curve, the points inwards. Each tooth is flat before, conrex behind: Wher rapidly diminish in size outwards; the outer ones are cutting, and almosi cquilateral. The teeth are double-rooted, a deep notch between the two roots. A sprace in the middle of the upper and under-jaw. The third tooth of the mpper-jaw smaller.

Oxyrhina, Agassiz, Fossil Fish. iii. Wuill. + Henle, Mug. Nat. Hist. ii. 1838. Plagiost. 68. Bonap. Faun. Ital. xxrii. 
1. Oxymina gompiodox. The Tilumon.

Oxrrhina gomphodon, Müll. f. Henle, Mlug. 68.

? Canis carcharias, Alitror. 388. (Copied from Ruysch, Thes. t. 6. f. 6 ).

Tiburon, Brude liamon. t. ii. 67.

Oxprhina, Agressiz, iii. t. C, f. 2. Fenill. 7l. (tceth).

Squalus rostratus, Sarerio, Macri. Atti. della Reale Aecademia, delle Scienze, Napoli, 1819, p. 55, t. 1, f. 2 .

Oxyrhina Spallanzanii, Bonap. Faun. Itul. Fusc. 26.

Cane di mare di Messina, Spallanzani, Viagg. t. 4, 325.

Lamna, Oten, Odlont.t. 5, f. 1. (teeth).

? Carcharias littoralis, De Kay, Nat. IIist. of New York, 351, pt. 1. Zool. 1842.

HaB.-The Ocean, Mediterranean.

a. Jaws and tail.

b. Jaws. New Zealand. Presented by E. Churton, Esq.

c. A portion of the under-jaw. Malta? Presented by Miss E. Atersoll.

2. Oxyrhisi grauci. Glaucons Tiburon.

Osyrhina glauca, Mïll. f. Henle, Plag. 69.

Hab.-Java.

3. Oxyrhixa pexcotata. Dotted Tiburon.

Squalus punctatus, Mitch. Trans, Lit. Phil. Soc. i. 483, 1815. (young).

Lamna punctatus, Storer, Massachusetts, Rep. 1\$5, pl. 3, f. 2.

De Kay, Nut. Hist. of Nex York, 352, pl. 63, f. 206, 1842.

HAB.-New Jork, Coast of Massachusetts.

\section{CARCHARODON.}

Snout, position of the fins, and spiracles as in the foregoing. Teeth three-sided, with serrated edges, as in the teeth of Carcharias, straight, equilateral, and without a ledge. No middle tootb. The third tooth of the upper-jaw is a little smaller than the first two and the next following ones.

Carcharodon, Smith, Illust. Znol. S. Afr. Miill. f. Henle, Mag. Nat. Hist. ii. 1838. Plag. 67. Bonap. Selac. Tab. Anal.

Carcharias, sp)., Agessiz. 


\section{Carcharodon Rovdeletil. The Lamia.}

Carcharodon Rondeletii, Miill. \&. Henle, Plag. 70. Lamia, Rondelet, 390. (Copied from Gesner, 204).

Canis Carcharias, Stenonis, Elementa Myolog. 90. (Copied from Jacob. Mus. Reg. pt. 1, s. 3, t. 1, n. 7). Valent. MIus. i. 65. Blas. Anat. An. tal), fol. 272, f. A, B.

Lamia, Battarra, Wus. Thirch. 137, 154. Adnot. t. 38, f. a. ? Carcharias verus, Agassiz, iii. t. F, f. 3. Feuill. 71. (teeth). Squalus (Careharias) vulgaris, Rich. Faun. Bor. Amer. iii. 288. Carcharodon Smithii, Miill. 5. Henle. Seluc. Tab. Anal, in Mem. Soc. Nat. Hist. Neufchatel, ii. 9, gen. 42.

Carcharodon Lamia, Bonap. Faun. Ital. Fasc. 24.

Carcharodon capensis, Smith, Illust. Zool. S. Afr. pl. 4, 1849. (female).

Ha B.--Mediterranean, Atlantic Ocean, Cape.

a. Stuffed. Cape Seas. From Dr. A. Smith's collection. Presented by the Zoological Society.

$b$. Jaws. Adult.

\section{CETORHINUS.}

Snout short, blunt. Small spiracles. Gill-openings very large, passing almost entirely across the throat. Teeth very small, numerous, conical, withont denticulations or side notches, the points curved backwards. Scales with small curred points, which are bent in all directions, so that the skin feels rough each way.

Cetorhinus, Blainr. Bull. Soc. Phil. 121, 1816. Jour. de Phys. $263,1816$.

Selache (Les Pelerins), C'ur. Règ. An. 2 ed. ii. 390. Mull. \&. Henle, Mag. Nat. Hist. ii. I838. Plagiost. Bonap. Faun. Ital. Selachus, De Kay.

\section{Cetorhixus maximus. Basking Shark.}

Cetorhinus Gunneri, Blainx. Bull. Soc. Phil. 121, 1816. Squalus maximus, Gumn. Dronth. iii. t. 2. Die Z̈̈̈ne Dronth. iv. t. 4, f. 1. Mïll. Prod. 38, n.315. Fabric. F. Gr. 130. Mohr. Fors. 60. Linn. Gm. 1498, 11. Bloch, Schneid. 134. Home, Phil. Trans. 1809, pt. ii. t. vi. 206. Flem. Brit. An. 164. Fabr. Naturg. d. F. Isl. 20. Nils. Prod. 114. Jenyns, Brit. An. 563. Mitch. Trans. New York, i. 486. 
Brugden, Leems, 158.

Basking Slark, Penn. Lirit. Zool. n. 41, pl. 13. (Conpied from S'hau, Gen. Zool. 327, pl. 149 (male), 150 (female). Encycl. Wéth. f. 19. Yarr. Brit. Fish. ii 396.

J.e Tres-grand, Brouss. 669), 18. Lacép. i. 207.

Pelerin Tres-grand, Dict. Sri. Nat. pl. 30.

I.e Squalus Pelerin (S̀qualns maximus), Blainv. Ann. Muséc, vii. t. i, f. 1. Anat.

Squalus elephas, Lcsueur, Ph. Ac. ii. 350.

Selache, Agassiz, t. F, f. 8 .

Selache maxima, Goyeur, Hamb. Mag. 24 band, 331. Miull. \&IIenle, Plag. 71.

Sqnalus isodns. Turerio Nacri. Atti della Reale Accademia delle Scien $=e$, i. 55, t. i. f. 1, t. ii. f. 2, Napoli, 1819.

Squalus (Selathe) maximus, Cur. Règ. Au. 2 ed. ii. 390. Rich. Four. Bor. Amer. iii. 291.

Selachus maximus, Dc Kay, Nat. Hist. of New York, 357, pl. 63, f. 208 (male), 1842.

Cetorlinus Homianus, Blainr. Bull. Soc. Phil. 121, 1816.

Cetorhinus Shavianus, Blainv. Bull. Soc. Phil. 121, 1816.

Har.-North Sea, Coast of New Jersey, West Coast of Scotland, Sc., Sc.

Rineodon, Smith, Mag. Nat. Hist. 5, 1838?

7. The gill-openings are large, and lie wholly before the breastfins. Spout-holes very small. Second back-fin and anal large. The upper lobe of the tail-fin elongated as in Carcharias. Tail-pits indistinct, or wanting, and without the keels found in Lannæ.Odontaspidiaxi.

Odontaspides, Miill. f. Henle, Plag. 73.

Triglochini, Bonap. Selac. Tab. Anal. 9, 1838.

\section{ODONTASPIS.}

A stout, threc-cornered flap on the upper edge of the nostril. The upper corner fold of the mouth is wanting. Cross plaits on the throat. The fore teeth very long, conical, simple, or with one or more very sharp, short, side denticles on the base; one or some small teeth follow on each side the front ones of the upper-jaw; the hinder upper-teeth are more cutting, and diminish rapidly 
in size. The upper and under teeth are alike in form. The root of the teeth is divided by a middle hollow into two branches. The second back-fin between the helly-fins and anal. Scales with three keels, which end in three projecting denticles.

Odontaspis, Ayassiz, Fossil Fish. ii.

Triglochis, Miill. 5. Henle, Mag. Nat. Hist. ii. 1838. Plagiost.

73. Bonap. Selac. Tab. Anal. \&, 1838.

Carcharias, Rafin. Caratt. 10, 1810. (not C'urier, 1817).

Galeorhinus, sp., Blainu. Bull. Soc. Phil. 121, 1816.

1. Odontaspis Taures. Taurus Shark.

Odontaspis Taurus, Miill. f. Henle, Play. 73.

Carcharias Taurus, Rufin. Caratt. 10.

"Trigluchis Mïllerii, Hiill." Smith, MSS.

Hab.-Mediterianear, Cape, Ocean.

a. Stufied. Cape Seas. From Dr. A. Smitlis collection.

b. Stuffed. Cape Seas. From the Zoological Society.

2. Odoxtaspis rerox. Fierce Odontaspis.

Squalus ferox, Risso, Ichth. 38. Hist. Nat. 122. Blainv. Faun. $F r . t$.

Odontaspis ferox, Ayassiz, iii. t. G, f. I. Bunap. Fann. Ital. Fasc. 26. Mill. f. IIenle, Play. 74.

Galeorbinus? ferox, Blaine. Bull. Soc. Phil. 121, 1816.

Haв.-Mediterranean.

a. Jaws.

b. Jaws.

8. Snout short and conical; very small spout-holes. The nostrils small, a short flap on their upper etgre. No labial cartilages. The gill-openings are small, as in Carcharias, and the last one stauds over the breast-fin. The tecth are three-siled, flat, with their cutting-edges not serrated, alike in the upper and under-jaw : the fore ones straight, equilateral ; the others somewhat curved ontwards. Fo middle teeth. A slight fold of skin, with a sharp erescentic edge betaind the teeth of the upper-jaw. Second hack-fin and an anal opposite to each other, very small. The upper lobe of the tail-fin very long, with a little pit at the ront. Small scales with thee prongs. Gut-valve spiral.--A Lopecias.

Alopecix, Miill. \&. Henle, Plaq.

Alopiadini, part, Bonap. Selac. Tab. Anal. 9, 1838. 


\section{ALOPIAS.}

The characters of tribe.

Alopias, Rafin. Caratt. ii.

Alopecias, Müll. \&. Henle, Mag. Nat. IHist. ii. 1838. Plag.

Carcharinus, sp., Blainv. Bull. Soc. Phil. 121, 1816.

Carcharias, sp., Cuv. Rèy. An. 2 ed. ii. 388.

\section{Alopias vulpes. Fox Shark.}

Vulpes, Rond. 387.

Vulpecula, Salv. 134, f. 42. (Copied from Jonst. t. 7, f. 3, Will. B.

6). Ruysch, Theatr. iii. 3.

Vulpes mitrina, Gesn. 1249.

Vulpecula marina, Aldrov, 396, 397.

Galeus cauda lunga, Klein, Misc. Pisc. iii. 10.

Long-tailed Shark, Penn. 14.

Renard marin, Perrault, Mém. p. servir à llHist. Nat. i. t. 15, 16. Brouss. 664, 14.

Renard de Mer, Euhamel, xxi. f. 1,2.

Zorrat de Mer, Bru. de Ramon. ii. 49.

Squalns cauda longiore quiun ipsum corpus, Artedi, Gen. Pise. 508.

Synon. 96.

Squalus renard, Lacép. i. 267.

Squalus vulpes, Gmel. Syst. Nat. 1464. Bloch, Schneid. 127. Jenyns, Brit. An. 498. Blainv. Faun. Fr. 94.

Carcharias vulpes, Risso, Ichth. 36. IIist. Nat. iii. 120. Flem. Brit. An. 167.

Alopias macromrus, Rafin. Caratt. 12.

Syualus (Carcharias) vulpes, Cuv. Règ. An. 2 ed. ii. 388.

La Faux ou Renard, Cnv. Rèy. An. 2 ed. ii. 388.

Alopias vulves, Bonap. Faun. Ital. Miull. S. Henle, Play. 74.

Carcharinus vulpes, Bluinv. Bull. Soc. Phil. 121, 1816.

Fox Shark, Yarr. Brit. Fish. 379.

Thresher or Long-tiiled Shark, Nitch. Trans. New York, i. 482.

Medical Repository, Second Decade, ii. 77, New York, 1805.

Nat. Hist. of New York, 348, pl. 61, f. 199 (female), 1842.

$\mathrm{H}_{\mathrm{AB}}$ - Mediterranean, Cape, Ocean.

a. Stuffed. Cape Seas. From Dr. A. Smith's collection.

b. Stufled. From the Chatham Museum. 
9. Mouth at the fore end of the snout. The nostrils reach to the mouth. The upper corner fold of the mouth is wanting. Spoutholes distinctly visible. The gill-openings small; the last one above the breast-fin. A spine before each back-fin. Tail short, with a notch on the under edge of the upper lobe.-Heterodontina. Heterodontus, Blainx. Bull. Soc. Phil. 121, 1816. Cestraciontes, Müll. f. Henle, Plag. 76.

\section{HETERODONTUS.}

Nostril-slit within the mouth, surrounded within and without by a roll of skin; the outer one turning inwards; the inner one is separated by a furrow from the upper-lip. Spont-boles small, ontside and somewhat behind the eyes. The eye under a leige-like fold of the skin of the head, which begins close behind the suont and runs straight from before backwards. Only the under half of the corner fold of the month is evident, and is moreover divided towards the middle line from the skin of the under-jaw by a furrow. The upper one is barely shown by a small notch. Pavement-like teeth, in the middle small and pointed, from three to five denticles tiled from the base towards the point, of which the middle one is the biggest, and which are worn out in the old fish; also even in those which are not upright; in old individuals the radical denticles are indistinct, or wanting. The lateral teeth are parement-like, rhomboidal, diminishing in bigness from the hindmost towards the first and back : they have a roll running in the direction of their longest diameter and a rough upper surface; altogether they remind one, by their form, of a winding spiral snail-shell. Gill-openings decreasing in size from before backwards, the last two moderately high above the breast-fin. Tail-fin short, with a distinct under lobe.

Heterodontus, Blaine. Bull. Soc. Phil. 121, 1816.

Cestracion (Les Cestraceons), Cuv. Règ. An. 2 ed. ii. 291. Müll. 5. Henle, May. Nut. Hist. ii. 88, 1838. Playiost. 76.

\section{Heterodontus Zebra. Chinese Cestracion.}

Cestracion Zebra, Gray, Zool. Misc. 5. Icon. Reeves, 174. Hardu. Cart. 52. Rich. Rep. Brit. Assoc. 195, 1845. $\mathrm{H}_{\mathrm{AB}}$, -China. a. Stuffed. China. Presented by J. R. Reeves, Esq.

b. Stuffed. China. 
2. Heterodontus Philippi. Port Jackson Shark.

Port Jackson Shark, Plilip, Voy. 283, 1790. Davila Catalog. i. 22, (teeth).

Squale Philip, Lacép. i. 283.

Squalus Philippi, Bloch, Scloneid. 134.

Cestracion Philippi, Agassiz, iii. t. d. Mill. \&. Itenle, Play. 76.

Gray, Ann. Nat. Hist. i. 109. Less. Dup. ii. pt. 1, 79. Poissons, pl. 3.

Cestracion Quoyii, De Fremenrille. Guérin-Ménérille, Mag. de Zool. Puris, 1840, liv. 9. Poiss. pl. 3. Owen, Odontl. t. 10, f. 4 , t. ii. f. 2.

Heterodontus Philippi, Blainv. Bull. Soc. Pliil. 121, 1816.

HAB.-Australia.

a. Stuffed. S. Australia.

b. Port Jackson. Presented hy R. Gunn, Esq. c, d. Stuffed. Japan. From Mr. Franks' collection. $e-g$. Jaws. Port Lincoln. Australia.

h. Skeleton.

3. Heterodontus pantherinus.

Cestracion pantherinus, Valent. Voy. Venus, Puissons, t. 10, 62. $\mathrm{HAB}, \longrightarrow$ ?

10. Head flat. Nouth and nostrils quite at the fore end of the same. Three-comered nasal-flap. Teeth extraordinarily small, conical, very numerous, card-like. Spout-holes very small. The gillopenings diminish in size backwards; the last one stands abore the breast-fin. The first back-fin far behind the anal; the second over it. Crescentic tail-fin without a notch in the npper lobe, with side keels and tail-pits. Gut-ralve serew-formed.-Rhin Eodontuna.

Rbineodontis, Miill. f. Henle, Plag. 77.

Lamnoidea, part, Miill. \&. Henle, Mag. Nat. Hist. ii. 5, 1838.

Alopiadini, part, Bonap. Selac. Tab. Anal. 9, 1838.

\section{RHINODON.}

The character of the tribe.

Rhineodon, "A. Smilh." Müll. \&. Henle, Mag. Nat. Hist. ii. 37, 1838. Bonap. Selac. Tub. Inal. 10, 1838.

Rhinodon, A. Smith. Müll. f. IIcnle, Plag. 77. 
1. Rhineodon trpicus. The Rhineodon.

Rhineodon typicus, Smith, Illust. Zool. S. Afr. pl. xxvi. 1849. Müll. \&. Henle, Plag. 77.

Hab.-Cape. Mus. Paris.

B. Dorsal-fin single; anal distinct; gill-slits six or seven. Squali (§3), Mïll. \&. Henle, Mag. Nat. Hist. ii. 1838. Plagiost.

11. Head flat. Nostrils with a small three-cornered flap. Upper corner fold of the month rery large; the under one small. Nictitating membrane wanting. Tongue adhering. The spout-holes upright, small. From six to seveu gill-openings, decreasiug gradually in size from first to last, all before the breast-fins. A middle tooth in the under-jaw. The next five or six teeth of the under-jaw form a saw, which ruus from above and within downwards and outwards; the fore and inner edges of the teeth are entire or finely serrulated throughout. The outermost jaw-teeth are low and flat. The upper-jaw teetl are longer, narrower, and more pointed: the first denticle or point is much longer than the rest; the outer edge thick, the inner one finely serrated, toothed towards the base. The foremost teeth form a heap, and are hook-formed from a broad base. The next following ones have one, or a pair of lateral denticles on the outer side. The outermost teeth as in the upper-jaw. Distinct lateral lines. The first back-fins between the belly-fins and anal, sometimes nearly over the anal. Tail-fin with a small under lobe, notched at the end, which is obliquely or directly truncated. No tail-pits. Gut-valie screw-formed.-Hexaxcmina.

Notidiani, Müll. f. Henle, Plag. 80.

Notidanini, Bonap. Selach. Tab. Anal. 9, 1838.

Monopterhinus, Blainv. Bull. Sac. Plitl.121, 1816. Jour. de Phys. $263,1816$.

Notidanus, Cur. Règ. An. 2 ed. ii. 340. Miull. \&. Henle, Mag. Nat. Hist. ii. 1838.

Six gill-openings.

\section{HEXANCHUS.}

Hexanchus, Rafin. Caratt. 10, 1810. Mrïl. \& Henle, Mag. Nat. IIist. ii. 1838. Plagiost. 80.

Notidanus, sp., Cuv. Règ. An. 2 ed. ii. 390. Bonap. Faun. Ital. Monopterbinus, sp., Blainv. Bull. Soc. Phil. 121, 1810.

1. Hexaychus griseus.

Piscis vacca Scilla, t. 1 (teeth), t. 27 (head), t. 28, f. 1 (the whole fish). 
Le Griset, Brouss. 665, 13.

Squalus griscus, Iinn. Gmel. 1495, 22. Bloch, Schneid. 129. Risso, Ichth. Nice, 6. Blaine. Faun. Fr.77.

Le Squale Griset, Lacép. i. 269.

Squalus vacea, Bloch, Schneid. 138.

Hexanchus griseus, Rafin. Caratt. 14. Miill. \& Henle, Plag. 80.

Notirlauns monge, Risso, Hist. Nat. iii. 129.

Squalus Notidiamus Grisens, Cur. Rèy. An. 2 ed. ii. 390.

Notidanus griseus, Bonap. 12. Ayessiz, iii. t. $c$, f. 2 (teeth). Fevill. 71.

Monopterhinus grisens, Blainv. Bull. Soc. Plit. 121, 1816.

HAB.-Mediterranean.

a. Stuffed. Adult. Isle of Wight. Presented by Capt. Swiuburn, R.N.

b. *Jaws. Isle of Wight. Presented by Capt. Swinburn, R.N.

c. Portion of under-jaw. From Dr. Mantell's collection.

\section{HEPTRANCHUS.}

Seren gill-openings.

Heptranchus, Rafin. Caratt. 10.

Heptanchus, Mill. S. Henle, Mag. Nat. Hist. ii. 1838. Plagiost.

Notidanus, sp., Cur. Rig. An. 2 ed. ii. 390.

Monopterbinus, Blaini. Bull. Soc. Phil. 121, 1816. Jonr. de Phys. 263, 1816.

1. Heptranchus indices. Indian Perlon.

Heptanchus indicus, Müll. \&. Henle, Plag. 82.

Notidiauus Grisets des Indies, Cuv. Reg. An. 2 ed. ii. 390, Note.

Notidauus indicus, Agassiz, iii. t.e, f. 1. Fcuill. 71. (teeth).

HaB.-Indian Ocean.

a. Stuffed. Cape Seas. From Dr. A. Smith's collection.

$b$. Stuffed. Cape Seas. From the Zoological Society of London.

2. Heptraxchus cinereus. The Perlon.

Le Perlon, Brouss. 668, 17.

Squalus ciuereus, Lim. Gmel. 1497, 26. Bloch, Schneid. 133.

Tenore, Soc. Pontan. Risso, Ichth. 24. Blainr. Faun. Fr. 80.

Le Squale Perlon, Lacép. i. 222.2. 
Le Perlon (Squalus Notidianus cinereus), Cuv. Règ. An. 2 ed, ii. 390.

Notidanus cinereus, Bmap. xii.

Monopterhinus cinerens, Blaine. Bull. Soc. Phil. 121, 1816.

Heptranchus cinereus, Miill. \& Henle, Plag. 81. Rafin. Caratt. 13.

HAB.-Mediterranean, Ocean.

a. Stuffed. From the Antaretic Expedition. Presented by the Admiralty.

C. Anal none; dorsal-fins two; nictitating membrane none. The five gill-holes all before the breast-fins; gut-ralve spiral; spiracles distinct.

Squali (\$ 4), Wiill. \&. Menle, Mag. Nat. Hist. ii. 1838. Plagiost.

12. A spine hefore each back-fiu.-Ancaxtina.

Acanthorhimus, sp., Blaine. Bull. Soc, Phil. 121, 1816. Jour. de Phys. 263, 1816. Miill. \&. Henle, Mag. Nat. Hist. ii. 1838. Spinaces, Miill. Henle, Plag.

Spinax, Cuv. Rèy. An. 2 ed. ii. 390.

Spinacini, Bonap. Selac. Tab. Anal. 4, 8, 1838.

\section{ACANTHIAS.}

Head flat. Large comer pits to the mouth. Two labial cartilages above, one helow. The mouth forms a very flut arch. Spoutholes big, behind, and somewhat above the eyes, a roll-like flap to the spont-hole, springing from its fore edge. 'The eye-openings are long. Teetl above and beneath, cutting with an almost lorizontal edge, and a point inclined ontwarils. The root of the tooth is higher on the inner part than on the onter, and has a longitudinal keel on the inner one; the outer part forms a round ledge towards the point of the tooth. First back-tin between the breast and bellyfins. Second betwixt the belly-fins and caudil. The upper lobe of the latter is the bigger one. A tail-pit exists in some. The males have on the outside of the ends of their appendages a moveable prickle or spine, with a slightly curred tip. Scales beart-shaped, with a middle point, and one or more keels.

Acanthias, Bonap. Selac. Tab. Anal. 8, 1838. Miill. f. Itenle, Mag. Nat. Hist. ii. 1s3s. Playiost. 81.

Acanthorhinus, sp., Blaine, Bull. Sore. Phil. 121, 1816.

Spinax (Acanthias) sp., Cut. l'é̀g. An. 2 ed. ii. 392, 1817.

Squalus, Ráafin. C'aratt. 
1. Acanthias Blainrillit. Blainville's Dog-fish.

Acanthias Blainvillii, Risso, Hist. Nat. iii. 133, f. 6. Miill. \&. Henle, Plag. 84.

Spinax Blainvillii, Bonap. ix. Agassiz, iii. t. B, f. 1, 6, 8 .

HAB.-Mediterramean, Ocean.

$a, b$. In spirits. Dalmatia. From Dr. Heckle's collection.

c. Stuffed. Cape Seas. From Dr. A. Smith's collection.

2. Acanthis vulgaris. Spined Dog-fish.

Acanthias vulgaris, Risso. Müll. \&. Menle, Plag. 83. Risso. Hist.

Nat. iii. 131.

Galeus acanthias, Klein, Misc. Pisc. iii. 8 (?), t. 1, f. 5, 6. Fabr. Squalus acanthias, Linu. Mus. Ad. Fr. 53. Faun. Suec. Retz.

305. Fabric. F. Gr. 126. Bloch, 85. (Copied from Encycl. f.

12). Gumel. Syst. Nat. 1500, 1. Bloch, Schneid. 135. Risso, Ichth. 40. Donovan, n. 82. Fabr. Isl. 29. Nils. Prod. 117. Blaine. Faun. Fr. 57, pl. 14, f. 1.

? Haae, Ström. Sönd. 280.

L'aiguillat, Brouss. 673, 22.

Squalıs pinna ani nulla, ambitu corporis subrotundo, Artedi, Gen. Pisc. 505.

Squale aiguillat, Lacép. i. pl. 10, f. 2, p. 270.

Spinax acanthias, Flem. Brit. An. 166. Bonap. Eann. Ital. t.

Jenyns, Brit. An. 505. Agassiz, Fossil Fish, ii. t. B, f. 3. Parn. Ichth. Forth. 260. De Kay, Nat. Hist. of New York, 359 , t. 64, f. 210,1842 .

Acanthorhinus acanthias, Blaine. Bull. Soc. Phil. 121, 1816.

Picked Dog-fish, Yarr. Brit. Fish. ii. 400.

Squalus (Spinax) acanthias, Cut. Règ. An. 2 ed. ii. 392. Rich. Faun. Bor. Amer. iii. 291, 1836.

Hab.-Mediterranean, North Sea, Ocean, South Sea.

a. Stuffed. New Holland?

b. Stuffed.

c. Stuffed. Presented by Gen. Hardwicke.

d,e. Stuffed. Cape Seas? From Dr. A. Smith's collection.

$f$. Stuffed. Cape Seas. From Dr. A. Smith's collection.

g. Young. English Coast.

h. Stuffed. Cape Seas? From Dr. A. Smith's collection.

i. Stuffed. 
j. Stuffecl. Firth of Forth, Scotland. From Dr. Paruell's collection.

$k$. In spirits. Dalmatia. From Dr. Heckle's collection.

$l, m$. In spirits. Mediterranean.

n. In spirits. Plymonth Sound. From Dr. Leach's collection.

\section{Acanthias uyatus. The Uyatus.}

Acanthias uyatus, Miill. \&. Henle, Plag. 85.

Squalus uyatus, Rafin. Caratt. 14.

Spinax uyatus, Bonap. ix.

Squalus iufernus, Blainv. Faun. Fr. 59, pl. 14, f. 5.

HaB.-Mediterranean.

\section{SPINAX.}

Head archer. Snout blunt. Nostrils at the end of the snout. Corner folds of the mouth very large, naked. The under one, in form of a naked ledge, runs lengthways round the under margin of the mouth and unites with its fellow. An upper corner cartilage of the month. Month little arched. Under-teeth as in Acanthias, but without the keel and apophysis of the base: the upper-teeth as in Scyllium, with a larger, straight, conical, middle prone, and two pointed lateral prongs on each side; the outer of which is the smaller. No tail-pits. No prickle on the male appendages. Bent hairs instead of scales.

Spinax, Bonap. Selac. Tab. Anal. 8, 1838. Miill. \& Henle, Mag.

Nat. Hist. ii. $1838 . \quad$ Plagiost. 86.

Acanthorhinus, sp., Blainr. Bull. Soc. Phil. 121, 1816.

Spinax, sp., Cuv. Règ. An. 2 ed. ii. 7, 392.

Centrina, sp., Loue, Proc. Zool. Soc. 1833.

Acanthidium, Lowe, Proe. Zool. Soc. 1839.

\section{Spinax niger. Black Centrina.}

Galeus acanthias, s. Spinax fuscus, Ray, 2l, 1). 9.

Der Schwarze Harfisch, Squalus spinax (Sorthaae), Gunn. Dronth. Gisel Schroft. ii. 285 , t. 7.

Squalus Spinax, Mïll. Prod. 37, n. 312. Gmel. Syst. Nat. 1501, 8. Bloch, Schmeid. 135. Nils. Prod. 116. Jenyns, Brit. An.

505. Bonap. Faun. Er, 60.

Le Sagre, Brouss. 675, n. 23. Lacép. i. 274. Risso, Hist. Nat. iii. 132. 
Squalus pinna ani carens, naribus in extremo rostro, Artedi, Gen. Pisc. 506.

Blaataske, Ascanias, 37.

Centrina nigra, Lou'e, Proc. Zool. Soc. 1833, pt. 1, p. 144. Acanthorhinus spinax, Blainv. Bull. Soc. Phil. 121, 1816.

Spinax niger, Bonap. Faun. Ital. 12. Müll. \&. Henle, Plag. 86. Ayassiz, iii. t. B, f. 4, 5, 9 .

Acanthidium pusillum, Lowe, Proc. Zool. Soc. 91, 1839.

HAB.-N. Sea, Mediterranean and Madeira.

\section{OXYNOTUS.}

Snout short, thick and flat. Nostrils near the edge of the same. Nasal-flap four-sided. The corner fold of the naked labial cartilages united above and below on the mesial line with the skin of the head. Spout-holes very large behind and somewhat above the eyes, haring an upward and downward direction, crescentic, with one flap. Upper-tceth slender, conical, and little cutting, straight, connected with the skin of the fore part of the jaw. The base of these teeth is notelsed in the middle. The under-teeth are either straight or nearly so, and the outcr ones inclined very slightly outwards, broader and flatter than the upper ones, very kecnly cutting, nearly equilateral, finely serrated on the edge. "The mirldlemost tooth is single, exactly equilateral; the base of the under-jaw teeth nearly four-cornered. The spine of both back-fins is enveloped to the point in the skin. Tail-fin without an under lobe, and having no notch. The males have appendages which are wholly soft, without a spine. Scales upright, points standing on a four-sided base.

Oxynotus, Rafin. Caratt. 1810.

Acanthorbinus, sp., Blaime. Bull. Soc. Phil. 121, 1816.

Centrina, Cuv. Rèy. An. 2 ed. ii. 392, 1817. Miill. \&. Henle, Mag. Nat. IIist. ii. 1838. Plagiost. 87. Bonap. Selach. Tab. Anal. 8,1838 .

\section{Oxynotus Centrina.}

Vulpecula, Belon. 63.

Vulpecula italica, Belont. 64.

Centrina, Rond. 384. (Copiesl from Gesner, 719). Jonst. vii. 5. Salivani, 157, f. 56, 57. (Copied from Willoughby, ii, 3). Ruysch, t. vii. f. 4, t. 31 , f. 1. Ray, Ichth. 21. 
Galeus centrina, Gesner, 1250. Jonst. t. 7, f. 4, 5.

Centrine, Mus. Worm. 273.

Galeus brevis crassus, Klein, Misc. Pisc. iii. 10.

Haa-therning, Pomtopp. Th. ii. t. 209.*

Squalus centrina, Brunnich, 3, n. 7. Miill. Prod. 37, n. 313. Bloch, Schmeid. 115, 134. (Copied from Encycl. Méth. f. 13).

Shaw, Gen. Zool. 153. Lim. Gmel. 1502. Rissn, Ichth. 42. Blainx. Fann. $F r .61$, pl. 15, f. 1.

L'humantin, Brouss. 676, 25. Lacép. i. 276, pl. 9, f. 3.

La Mielga, Cornide, 128.

Squalus pimna ani carens, ambitu corporis triangulari, Artedi, Gen.

Pise. 506.

Oxynotus centrina, Rafin. Ind. 45, 60.

Centrine humantin, Dict. Sci. Nat. pl. 31.

Centrina Sitviani, Risso, Hist. Net. iii. 135. Müll. \&. Henle, Play.

87. Bonap. 14.

HAB.-Mediterranean.

a. Stuffed, From the Chatham Museum.

\section{ACANTHORHINUS.}

Head flat. Nustrils near the fore end of the snout. Corner folds of the mouth naked, very large and deep. A slit of the skin proceeds backwards from the same. Sjout-holes behind and above the eyes, with a flap. The fourth and fifth gill-holes are approximated to each other. Teeth in the under-jaw as in Acanthias, bnt with the edge less lying; this is either indistinctly toothed or entire. The root has a middle upright keel with a cross lobe on the onter side standing forwards. The upper teeth straight, equilateral, three-cornered on a four-sided base, with a longitudinal keel and a cross one; no dentienlations aud no supplementary prongs. The longitudinal keel is continued over the fore surfice of the tooth, wherehy it becomes thicker in the middle. No middle-tooth. No tail-pit. 'The males have a prickle in their appendages, which is placed on their outer side before their ends.

Centrophorus, Miill. \&. Henle, Mag. Nut. Hist. ii. 1838. Plagiost.

89. Bomap. Selac. Tab. Anal.9, 1838.

Acanthorhinus, sp., Blainv. Bull. Soc. Phil. 121, 1816.

? Acanthidium, sp., Lome.

Scymuus, sp., Cuv. Règ. An. 2 ed. ii. 393.

Lepidorhinus, Bonap. Selac. Tab. Anal. 9, 1838. 
1. ACanthorhines granulosus. Granulose Shark.

Centrophorus granulosus, Mïll. \&. Ilenle, Plag. 89.

Squalus gramulosus, Bloch, Schncid. 135.

?Acanthidium calceus, Lowe, Proc. Zool. Soc. 92, 1839.

Acanthorhinus granulosus, Blainv. Bull. Soc. Phil. 121, 1816.

HA3.-Mediterranean, Sicily.

2. Acanthominus squamosus. Scaly Shark.

Centruphorus squamosus, Miill. \&. Henle, Plag. 90.

L'écailleux, Brouss. 675, 24. Lacép. i. 284.

Sqqualıs squamosus, Limn. Gmel. 1502, 28. Bloch, Sclneid. 136.

Shav, Gen. Zonl. 328.

Siqualus (Scymnus) squamosus, Cur. Rèy. An. 2 ed. ii. 393. Acanthorbinus squamosus, Blainv. Bull. Soc. Phil. 121, 1816. 1.epidorhinus squamosus, Bonap. Selac. Tab. Anal. 9, 1838. Hab. —_ Mus. Paris and Berlin.

\section{CENTROSCYLLIUM.}

Upper and under-tecth similar, straight, pointed, and with one or two adjoining prongs on each side as in Seyllium. On account of the similar constitution of the tecth in both jaws distinguished from the dentition of the genus Spinax of Buonaparte. Scales of the skin pointed with a stellate base.

Centroseyllium, Miill. \&. IIenle, Plag. 191.

\section{Cextroscrluium Fabricit. Fabricius' Shark.}

Centroscyllinm Falurici, Miill. \&. Ilenle, Plag. Nachtr. 191.

Spinax Fabricii, Reinhardt.

II A B.-Greenland.

13. The back-fins without spines.-Daratiana.

S'cymni, Mïll. \&. Henle, Plag.

Sicymnini, Bomap. Selac. Tab. Anal. 9.

Ścymuns, Cuv. Règ. An. 2 ed. ii. 393. Müll. f. Henle, Mag. Nat. IIist. ii. 1838. 


\section{DALATIAS.}

Head either flat or compressed on the sides. Spout-loles far behind and somewhat abore the eyes. The teeth of the upper-jaw wholly straight, or upright on the jaw, hooked, the under ones broaler, with an upright or inclined edge. Gill-openings small, the fourth and fifth only a little approximated. No tail-pit.

Dalatias, Rafin. Caratt.

Scymnus, part, Cux. Règ. An. 2 ed. ii. 392.

Scymnus, Miill. f. Henle, Mag. Nat. Hist. ii. 1838.

1. The upper comer fold of the mouth is connected by a skinus ledge, under which before the teetl there lies a very conspicuous skinny lip, much longer than the upper-teeth: the under corner fold of the mouth passes into a lip which is very free, but is not separated from the skin of the throat by a furrow. The skin forms beneath the eve a free border towards the large naked region of the corner of the month. The under-teeth are lancet-formed, convex in the middle of the anterior surface, sharp on the sides, the lancet-shaper point rising from a high base. The under mid-tooth, which is no smaller than its neighhours, has a base with both its sides equal (and a notch at the commencement of the root). The root is larger than the point; two lobes on the elge of the jaw, with a notch between the two lobes, from which there rums a channel up to an opening in the middle of the root of the tooth. The remaining teeth in the under-jaw liave an indentation on their inner sides wherein the root of the adjoining tooth lies: their root is alsu two-lobed and has the same channel. The upper-jaw teeth stand straight forwarts, and their sides are inclined outwards. The claspers are without at spine.-DALATis:.

Dalatias, Rafin. Caratt.

Scymnus, Miill. f. Henle, Plag.

Scymuus, sp., Cuv. Rig. An. 2 ed. ii.

\section{Dalatias Lichia. The Lichia.}

Canis centrinæ Salriani similis absque aculeis, Sten. Hist. Diss. Pise. 138.

Seehund, Valentini, 11. m. 1, 484.

Liche, Brouss. 67\%, 26.

Squalus americanus, Linn. Ginet. 1503. Bloch, Schneid. 1:36. Blainr. Faun. Fr. 63, pl. 15, f. :2. 
Squale liche, Lacép. i. 279, t. 10, f. 3.

Squalus nicéen, Risso, Hist. Nat. iii. 136, f. 4.

Scymnus lichia, Bonap. Famn. Ital. 14. Agassiz, iii. t. F, f. 7. Miill. \&. Ilenle, Plag. 93.

Dalatias sarophagus, Rafin. Caratt. t. 13, f. 2.

HAB.-Meditcranean, Ocean, Cape Breton, Bayonne.

a. Stuffed. Maderia. From Mr. Lowe's collection. Presented by the Zoological Society.

2. Dalatias brasiliensis. Brazilian Lichia,

Scymnus (Scymnus) brasiliensis, Cuv. Miill. \&. Henle, Plag. 92. Scymnus brasiliensis, Cuv. Freycinet, Voy. 198.

Hab.-Isle of France, St. Jago, Rio de Janeiro.

2. The skin forms a very large slit at the corner of the mouth, and a ledge covering the dental eartilage beneath, which is wanting above. Upper corner fold of the mouth very large, and naked, under one very susall. The upper teeth small, much longer than broad, conical, little cutting; the fore ones and the adjoining ones straight; the outer ones bent slightly, somewhat outwards; all without serratures. An npright keel on the basal part of the anterior surface; the root notcled in the midrle. Many rows stand upright together. The under tceth are much broader and longer, with a lying edge, and a point inclined outwards as in Acanthias, without serratures. The root long, flat, with an upright keel on the anterior surface, excavated lengthways on the sides. The outer edge of the base, which is higher than brotd, is conrex; the inner one shallowly excavated; the under one rounded, and notched in the middle. The males have a spine in their claspers.

-Somniosus.

Somniosus, Lesueur, Ann. Nat. Sci. Philad. 1.

Læuargus, Mrill. §. Henle, May. Nat. Hist. ii. 1838. Plagiost. 93.

Scymnus, sp., Cur. Règ. An. 2 ed. ii. 392. Flem. Brit. An. 106.

\section{Dalatias (Somniosts) boliealis. Northeru Shark.}

Scymmus (Læmargus) borealis, Müll. \&. Fenle, Play. 93. Guim.

Voy. Poland, Poissons, t. 22.

Carcharias Haa-Skierding, Gunn. Dronth. ii. 299, t. 10, 11.

Squalus carcharias, Mull. Prod. 38,

Carcharias, Mohr. Fors. 57. 
Squalus microcephalus, Bloch, Schneid. 135.

Somniosus brevipinna, Lesueur, Phil. Journ. i. pt. 2, p. 22:2.

Squalus borealis, Scoresby, Arct. Reg. i. 358, t. 15, f. 3, 4.

Scymuus borealis, Flem. Brit. An. 166. Jenyns, Brit. An. 506.

Squalus (Scymnus) glacialis, Fabr. Isl. 23.

Scymnus micropterus, Valenc. Nouv. Ann. du Mus. i. 455, 20.

Squalus glacialis, Nils. Prod. 116.

Greeulaud Slıark, Yarr. Brit. Fish, ii. 403.

Squalus norwegianus, Blainv. Fann. Fr. 61.

Squalus (Scymuns) Gunneri, Rich. Faun. Bor. Amer. iii. 313.

Scymnus brevipinua, De Kay, Nat. Hist. of New York, 361, pl. 61, f. 202, pt. 1. Zoul. 184:2.

HAB.-North Sea.

$a, b$. Stuffed. English Cuast. Presented by Messis. J. \& C . Grove.

\section{Dalatias (Somnosus) bispinatus.}

Scymnus (Læmargus) Labordii, "Quoy. et Gaim." Miell. \&. Henle, Plag. 94.

Scymuus bispinatus, Leiche Laborde, Quoy. 5- Gaim. Freyc. 19\%, pl. 44, f. $1,2$.

Scymnus mauritianus, Quoy. \&. Gaim. Dict. Class, liv, ii.

HAB.-Isle of France, Isle of Bourbon.

5. Delatias (Sonviosus) rostrates.

Scymnus (Læmargus) rostratus, Miill. \& Henle, Plag. 95.

Seymus rostıatus, Risso, Hist. Nat. iii. 138, f. 7.

$\mathrm{H}_{\mathrm{AB}}$. - M editerraneau Sea.

\section{ECHINORHINUS.}

Head flat. Corner pits of the mouth reuote. Tougue bound down. Teeth hroad and low, with a nearly horizontal edge, which is turned inwals somewhat beyoud the root, equal in both jaws. The side edges with from one to three successive denticles, which diminish in size from the edge towards the root. In the middle of the under-jaw a gap with a very small mid-tooth of a pyramidal shape. First back-fin over the belly-fins; the second betiveen the 
belly-fius and tail-fin. Tail-fin without an under lobe. Gill-openings not very wide; all before the breast-fins.

Echinorhinus (spinosus), Blainv. Bull. Soc. Phil. 121, 1816. Jour. de Phys. 1816. Mïll. S. Ilenle, Pleg.

Echinorrhimus, Miill. \&. Henle, Mag. Nat. IIist. ii. 1838.

Gauiodns, Agassiz, Poiss. Fos.

\section{Ecinnoritinus spinosus.}

Le Bouclé, Brouss. 672, 21.

Squalus spinosus, Limn. Gmel. 1500, 27. Bloch, Schneid. 136.

Squale Bouclé, Lacép. i. 30, t. iii. f. 2. (Copied from Encycl. 11, 11.

22). Risso, Ichth. 42 .

Scymuus spinosus, Risso, Hist. N'at. iii. 136.

Squalns (Scymuus) spinosus, Cur. Reg. An. 2 ed. ii. 393.

Leiche bonclée, Dict. Sci. Nat. pl. 28, f. 2.

Eehinorhinns spinosus, Blainv. Bull. Soc. Phil. 121, 1816. Bonap. 13. Mïll. \& Henlc, Plag. 96. Yarr. Brit. Fish. 5332.

Squalus (Echinorlinus) spinosus, Blaint. Faun. Fr: 66.

Goniodus, Agassiz, Poiss. Fos. iii. t. E, f. 13.

Echinorhinus obesus, Smith, Pisc. pl. 1 (male), 1339.

Haв.-Mediterranean, Cape Seas, Ocean.

\section{Fam. 3. SQUATINIDE.}

Body flat above and below. Mouth at the fore end of the snont. Eyes on the dorsal aspect. Spout-holes large behind the eyes. The large anteriorly expanded breast-fin interposes the fore end of its root between the head and horly, and is divided from them by a furrow. In the depth of this furrow lie the gill-openings, which follow close to one another and are separated merely by folds of skin.

Squatina, Dum. Zool. Anal. 1806.

Rhina, Rafin. Caratt. 1810.

Squatina, Blainr. Bull. Soc. Phil. 121, 1816. Jour. de Phys. 263, 1816. Miill. \& Henle, Mag. Nat. Hist, ij, $183 \mathrm{s.}$

Squatinæ, Miill. \&. Henle, Play. 99.

Squatinini, Bonap. Selac. Tab. Anal. 8, 1836.

Squalidxe anomali, Bonap. Sclac. Tab. Anal. 4, 1836. 


\section{SQUATINA.}

Spout-holes much larger than the eyes, crescentic, convex before, concare behind, as far belind the cyes as the eyes are from the point of the suout. Ahove the mouth a broad lip, on whose fore border the nostrils stand, notched in the middle. On each side of the nostrils a long lappet. The nostrils witl a flap at the inner corner, which is divided into many scalloped lappets; on the outer corner of the nostril a broad indented tlip of skin. A ledge of skin commences at the outer corner of the nostril, and rnnning on the side of the head, terminates at the place where the fore point of the breast-fin abuts against the heal. This ledge is of the same breadth with the interval between the opposite eves and spout-holes. Eye-openings round, in a line with the nostrils and spont-holes. Uuder-teeth interrupted in the middle; also abuve no mid-tooth, in the fore part conical teeth, little trenchant; the teeth scattered with spaces. 'Two upper and under corner cartilages of the mouth, above them a rery decp recess under a vault of shin. Both hackfins upon the tail. This is compressed from above to beneatl, broader than high, with a keel of skin on the side. The under part of the tail-fin is longer than the upper one. The upper lohe withont a notch. Belly-fius large. The male claspers small and weak. Scales conical, vanishing in a terminal point.

Squatiua, Drem. Zool. Anal. 1806. Blaine. Bull. Soc. Phil. 121, 1816. Jour. de Phys. 263, 1816. Rafin. Anul. Nat. 93, 1s15. Hiill. Henle, Play.99.

Rhina, Klein. Rafin. C'aratt. 9, 1810.

1. Solatina vulgaris. Angel-fish.

Squatine, Romel. (Copied from Aldrorand, 472).

Squatina, Belon, 78. Salriani, 152, f, 53. (Copied from Jonsion, xi. 7). Willoughby, D, 3, Ruysch, Thes. xi. 7. Hoscardo. 225. Ray, 26, 1. 6. Duhumel, sect. ix. pl. 14, f. 1-4. Rhina, Klein, Wisc. Pise. iii. 14. Kafin. C'uratt.9.

Squalus capite plagio-plateo, ore in apice capitis, pinna ani mulla, naribus cirrosis, Gronov. Act. I ps. 1. 5. MLss. i. 63, 137. Angel-fish, Borlase, C'omv. 5, n. 12. Yarr. Brit. Fish. ii. 407. Angel, Pennant, t. xii.

L'Ange, Brouss. 67s, 27.

Squalus squatina, Brumich, 5. Bloch, 116. (Copied from Encycl.

t. 5, f. 14). Linn. Gmel. 1503. Bloch, Schneid. 137. Donov.

i. 0.17 .

Angelo o peje angel, Comide, 129. 
Angel Shark, Shaw, Nat. Misc. 906.

Squalus pinua ani carens, ore in apiee capitis, Artedi, Gen. Pisc. 507. Synon. 95.

Squale ange, Lacép. i. 239, pl. 12, f. 1. (Copied from Shau, Gen. Zool. 356, t. 155$)$.

Squatinat vulgaris, Risso, Ichth. 45. Miill. f. Ilenle, Plag. 99. Flem. Brit. An. 169.

Rhina squatina, Rafin. Iud.45. Caratt. 14.

Squatine ange de mer, Dict. Sci. Nat. t. 21.

Squatina aeuleata, Lesuewr, Phil. Ac. i. t. 1.

Squatina augelus, Risso, Ilist. Nat. iii. 139. Cuv. Rey. An. 2 ed. ii. 394. Jenyns, Brit. An. 507,

Squatiua Dumerilii, Lesneur, Jour. Acad. Sci. i. 225, pl. 10, 1817. De Kay, Nat. Hist. of New York, 363, pl. 10, pt. 1. Zool. 1812 .

Hab.-European Seas.

a. Stuffed. Kingston.

b. Stuffed. Adult. English Coast. Presented by Mr. Booker.

c. Stuffed. Ailult. From the Chatham Museum.

d. Stuffed. Half-grown. English Coast.

$e, f$. Stuffed. Young. English Coast.

g. Stuffed. Young. Firth of Forth. Presented by Dr. Parnell.

$h$. Stuffed. Half-grown. Firth of Forth. From Dr. Paruell's collection.

i. Stuffed. Young. Plymonth. Presented by Lient. H. F Spence, R.N.

j. Stuffed. Young. English Coast.

$k$. In spirits. Young.

l. In spirits. Young. Fotal state.

2. Squatina frubriata. Fringed Angel-fish. Squatina fimbriata, Mïll. S. Ilenle, Plag. 100. HaB.-Mediterranean.

3. Squatina Angelina.

Squatiua Angelina.

a. In spirits. Surinam. From Mr. Franks' collection. 


\section{Sub-section II. RAII.}

Plagiostomi with flat bodies and spout-holes; gill-slits five before the belly-fins and under the pectorals; the eyes with an adhering upper eyelid or withont au eyelicl, with a complete scapular ring and naso-pectoral cartilages.

Pisces cartilaginei plani et lati, Ruy, Syn. Pisc. 23 .

Raia, Linn.

Les Raies (Raia), Cur. Règ. An. 2 ed. ii. 373.

Platosomia, Rafin. Anal. Nat. 93, 1815.

Rajaæ, Mill. Alh. Akud. Berl. 18:36. Plagiost. 103.

Raidx, Gruy, Syn. B. M. 148, 150, 1842.

Dumeril (Zoologie Analytique, 101, 1806, 8vo.) dirides the Plagiostomes thus :-

A. Branehial holes below; body flat.

1. Torpedo.-Tail short; body smooth, naked.

2. Raia.-Tail long, narrow at the hase.

3. Rhinobatus.-Tail long, very thick at the base.

B. Branchial holes lateral; body rounded.

4. Squatina.-With teeth; pectoral-fins niched.

5. S'gnalus.-With teeth; pectoral-fins eutire.

6. Aodon.-Without teeth.

Rafinesque (C'aratteri Nuovi Generi, 1810, 8vo.) proposes and characterizes the following genera of rays (Ruiu) :-

1. Leiobatus (Panduratus). - 2. Dipturus (Batis). - 3. Dasyatis $\left(\mathrm{Ujo}_{0} .=\mathrm{U}\right.$ roxys $\left(\mathrm{U}_{\mathrm{go}}\right)$, Index.

In his Analyse de la Nature, 1815, he formed the Rays into a family he called Platysomia, containing the following genera:1. Rhinobatus, Dumeril.-2. Platopterus $=$ Raia, Limn.-3. Leiobatus.-4. Epinotus.-5. Lymmea (afterwards changed to Noclins, p. 2:20).-6. Torpedo, Dnmeril.-7. ilipturus.-8. Mobula.-9. Ictetus. -10. Cephaleutherus.-11. Sephenia. - 12. Megalatus.-13. Dasyatus.-14. Uroxys.-15. Apturus. The names in Italic are new, but lhe neither gives types nor characters, so that it is impossible to understand for what they are intended. 
II. De Blainville (Bull. Soc. Phil. 121, 1816, and Jour. de Phys. 262, 1816), divides the Rays (Raia) into eight sub-genera, thus:1. Dasybatus ant R. communis, - 2. Trigonobatus aut R. pastinacæ.-3. Etobatus aut R. aquilæ.-4. Dicerobatus aut R. cormutæ. -5. Leiobatus aut R. lævis. - R. cruciatus. -6 . Narcobatus aut $R$. torpedinus. - 7. Rhinobatus aut $R$. squali. -8 . Pristobatus aut $R$. serratæ.

Cuvier (Régne Animal, 2 erl. ii. 394, 1829) divides these animals thus:-

I. Pristis.

II. Raja, subdivided thus:- 1 . Rhinobatus (* Rlynehobatus. ** Rhinobatus, Miill. y. Henle) -2. Rlina.-3. Torpedo.-4. Raia. -5. Trygon. - 6. Auacanthus. - 7. Myliobatis. -8. Rhinoptera. 9. Cepbaloptera.

Mïller and Henle (Mag. Nat. Hist. 89, 1838) give the following outline of their arrangement:-

I. Pristis.-Which should be placed next the sharks, including

1. Pristiophorus. - The branchial apertures on the side of the neck before the pectoral-fins, which begin with a slender hase as in the sharks; the fifth branchial opening close to the fourth, as in many Scyllia ; teeth pointed. P. cirrhatus.

2. Pristis.-The teeth pavement-like; the branchial apcrtures on the lower surface, as in other skites.

II. Rhivobatis.-In two divisions and fire genera, thus :-

a. First dorsal-fin opposite to the abdominal ones; caudal-fin ending in tuo lobes; mouth undulated.

1. Rlima, Schneid. - The nasal-valres extending to the interior comer of the nostrils; body orbicular; tecth round.

2. Rhynchobatis, Mïll. \& Henle.-The nasal-valve does not extend to the interior or corner of the month; budy oval, as in Rhinobatus; teeth broader than long, elliptical.

b. The two dorsal-fins placed upon the tail; extremity of the caudal-fin cut obliquely, forming only one lobe.

3. Rhinobatus.-The nasal-valve like Rhynchobatis. 
4. Platyrhina, Müll. \& Henle.-The nasal-ralve extends beyond the inner corner of the nostril nearly to the middle of the snout, which is obtuse, and the body orbicular, approaching to Torpedo.

5. Trygonorrhina, Müll. \& Henle. - Tail of Rhinobatus, with nose of Trygon.

III. The Torpedines contain four genera:-1. Torpedo. -2 Narcine, Müll. \& Henle.-3. Astrape, Mull. \& Henle.-4. Temera, Gray.

IV. The true Rasæ contain three genera:-

1. Raia, Cuv.

2. Sympterigia, Mïll. \& Henle-Tail of Raia; the pectoral-fins, which do not reach the keel of the snout in the true Raja, in this genus extend to the mesial lines, touching each other with their interior edges; the abdominal tin is not divided into two lobes by an incision as it is in Raja.

3. Uraptern, Müll. \& Henle.-Differs from Raja only by the want of a caulal-fin.

The genus Propleygia, Otto, is founded on a kind of monstrosity, which is not seldom met with in skates.

V. The Trygons, Cur., contain the following genera :-

1. Trygon (II ill. \& Henle), or Sting Rays.-The teeth are elliptical; the mouth transverse. They are divided into three subgenera, thus:-

a. Trygon.-Tail with a fiu above and below.

b. Hemitrygon.-Tail with a fin on the lower side only.

c. Himantura.-Tail without any fin.

2. Pteroplatea, Müll. \& Henle. - The Sting Rays with the body broader than long; the tail shorter than the body; the teeth terminating in one or three poinis.

3. Taniura, Miull. \& Henle.-Tail with no upper fin; lower one extending to the tip); teeth pointed, with an elliptical base : mouth undulated; the projecting part of the upper-jaw forms a sharp edge on each side.

4. Hypolophus, Müll. \& Henle.-Tail very high, with lower fin not reaching to the tip; teeth hexagonal, very small in the middle of the upper-jaw, and large on the sides.

5. Trolophus.-Tail with a fin at the tip; teeth as in Raja, bearing in the middle a wreath or point. 
VI. Another family bas the tail of Trygon, but wants the sting on the tail.

1. Anacanthus, Ehrenb.-Tail withont any fin.

2. Urogymnus, Miill. \& Henle.-Tail with a low fin on the upper side, not reaching to the tip.

VII. The MYLIOBaT1s, Cuv., form a family with large tecth, arranged as in a pavement or like mosaic-work; the pectoral-fins are separated from the head; the tail has a fin in its root, and a spine behind the fin.

1. Myliobatis.-The teeth large in the middle, and small on the sides of the jaw; the nasal-valve has a smooth edge; the fins of the head united.

2. Etobatis, Müll. \& Henle.-The fins of the head united by the lower-jaw project far beyond the upper one; only one row of teeth in each jaw; the nasal-valve deeply cut.

3. Rhinoptera, Kiuhl.-The fin on the head witb a central excision; teeth liexagonal; plates large in the middle of the jaws, diminishing in size as they reach the sides.

VIII. The Cephalopteræ eontain two genera:-

1. Cephaloptera, Dum. - Mouth on the under side of the body; teeth small and pointed, or like tnbercles in both jaws.

2. Ceratoptera, Miill. \& Henle. - The month on the top of the head; the teeth, which are distinct only in the lower-jaw, are little scales or leaves.

M. Charles Buonaparte (Selachorum Tabula Analytica, 1838, 4to) proposed to divide the family Raidæ into the following tribes and genera:-

I. Raidæ veri.-Body ending abruptly in a slender tail.

1. Cephalopterini. - Head truncate, two-horned; tocth minute, placed in serics; pectoral-fins very broad; tail rery slender, long, spine-bearing.-Cephalopterina.

1. Ceraloptera.-Month superior; teeth small, seale-like.

2. Cepilatoptera.-Mouth inferior ; teeth small, acute, or tuberculate in both jaws.

2. Myliobatini.-Head orate, produced: teeth large, flattened, tessellated; pectoral-fins very broad; tail very slender, spine-bearing. -Myliobatina. 
3. Rminopter.1.-Head naked; teeth six-sided; rentral larger.

4. Elobates. - Head entire; mandibles prodneed beyond the maxilla ; nasal-valve deeply cut; teeth in one series.

5. MYLtobates.-Head entire: nasal-valve truncated; tecth central, large; lateral small, in many series.

3. Head enclosed by the pectoral-fins; teeth small, in quincuncial order.-Raiana.

A. Acanthini.-Tail slender, finless and armless.

6. LRogymvis.-Lower eandal-fin narrow.

7. Avacasthus.-Tail finless.

B. Tryonini.-Tail slender, with a strony doubly serrated spine.

8. Unocophes.-Tail-fin terminal: teeth tesselliform.

9. Hrpolophus. - Teeth hexagonal, in centre of maxilla very small, at the sides larger; lower eandal-fin very broad.

10. Teniura. - Teeth aente, hase elliptieal; mouth waver; margin of the jaws exerted, each eultriform; lower caudal-fin sul)apical ; upper none.

11. Pteloplatia.--Teeth one or three, enspid; body broader than long; tail sborter than the bolly.

12. Hmaxtrra, - Teeth elliptieal, transversely keeled; dorsalfins none.

13. Hemrrigox. - Teeth elliptical, transversely kecled; upper dorsal-fins none.

14. Trigov. - Teeth elliptical, transversely keeled; upper and lower dorsal-fins distinet.

C. Raini.-Tail elongate, with two dorsals; body rhombunidul.

15. Uraptera. - Candal none; jectoral-fins liardly produced beyond the middle of the bcak ; ventrals two-lobed.

16. Sympterygla. - Candal distinet; pectoral-fins produced beyond the middle of the beak, attaining the _- ; ventrals onelobed.

17. Rala.-Caudal-fin distinet; peetoral-fin hardly produeed be. yond the middle of the beak; ventrals two-lubed; beak acute. 
17*. Batrs. - Caudal-fin distinct; pectoral-fin hardly produced beyond the middle of the beak; ventrals two-lobed; beak nonc; tail with clectric organs.

II. Raidæe anomalæ.-Body gradually tapering to the tail.

t. Torpedini. - Body orbicular, smooth; head rounded; tail depressed; moderately long.

18. Temera. - Dorsals none; boly ronnded; spiracles near the eyes; mouth slender; internal labial-valves to botlı jaws.

19. Astrape.-Dorsal one; body rounded; spiracles near the eyes; mouth slender ; internal labial-valres to both jaws.

20. Nuncise.-Dorsals two ; body roundish or angular; spiracles near the eyes; mouth slender; internal labial-valves in only one jaw ; teeth extended beyond the edge of the lips.

21. Torpedo. - Dorsals two; body rounded, truncated in front; spiracles far from the eyes; mouth larger.

5. Rhinobatina. - Body rhomboidal, elongated, beaked; tail thick, fleshy; dorsals two, fur apart; caudal apical.

* Dorsals both opposite to the ventrals.

22. Trygonorhina.-Body rhomboidal; beak triangular; caudal obliquely truncated, one-lobed.

23. Platy rhina.-Body orbicular ; beak scarcely produced; caudal obliquely truncated, one-lobed; nasal-ralve elongate.

24. Rhinobatus.-Body oval; caudal obliquely truncated, onelobed; nasal-valve scarcely produced.

* Front dorsal opposite to the rentral.

25. Rirychobatus. - Boly oval; caudal two lobed; nasalvalves scarcely produced to the inner angle; mouth wared; teeth broad, elliptical.

26. Rinns. - Body orbicular; caudal two-lobed; nasal-valres produced to the inner angles; mouth waved tecth rounded.

6. Pristidini.-Body elongate, depressed in front; beak very long, fat, bony, spined on each side.

27. Pristis.-Teeth gramular; gill-slits inferior.

28. Pristidophorus.-Teeth acute; gill-slits lateral; nose with free beards; eyebrows free. 
Mr. Swainson (Cabinet Cyclopadia, ii. 319, 1839) divides these animals thus :-

I. Pristisea. - 1. Pristis.

II. RaID.E.

Sub-fam. 1. Trygonince (String Rays). - 1. Trygon. - 2. Pastinaca.-3. Pteroplatea.-4. Raja.-5. Anacanthus.

Sub-fam. 2. Pterocephaline (Eagle Rays).-6. Myliobatis. - 7. Rhinoptera. - 8. Cephaloptera. - 9. Etobatis. - 10. Pterocephala, Swains. $=$ Cephaloptera, Dum.

Sub-fam. 3. Torpedince (Torpedo Rays). - 11. Torpedo. - 12. Temera.

Sub-fatn. 4. Squatina.-13. Squatina.

Sub-fum. 5. Rhinobatina.-14. Rhinobates.-15. Rhina.

\section{Fam. 4. PRISTISID王.}

The form of the body approaches most nearly to those sharks which have the breast-fin distinctly set off from the head, and not reaching to the belly-fins. The snout is prolonged into a long saw, which bears teeth inimplanted on the lateral edge. The first hack-fin stands close behind, or some distance above the belly-fins. The cuticular keel of the tail is not continued to the sides of the tail-fin. The skin is sleek, clothed with very small, flat, roundisl, or sixcornered scales, planted like paring stones.

Pristides, Mïll. \&. Henle, Plag. 105.

Squatinorair, part, Miill. \&. Henle, Plag. 103.

Scymni, part, Muill. \& Henle, Play. 91.

Pristis, Lath. Trans, Limn. Soc. ii. 282. Cuv. Règ. An. 2 ed. ii. 394.

Pristobatus aut Raja serratæ, Blainv. Bull. Soc. Phil. 121, 1816. Jour. de Phys. 262, 1816.

Pristinæ, Suains. Cab. Cycl. ii. 219, 1839.

\section{PRISTIOPHORUS.}

The snout is greatly lengthened, and is beset on both sides with longer and shorter hooked spines, so that it resembles the saw of Pristis; the prickles are only attached to the skin, not implanted. 
A long barbel on the under surface of the suout. Mouth transverse. Tecth short prickles on a roundish base, resembling the teeth of the male rays, pavement-like. The first back-fin between the breastfin and belly-fins. A keel on the side of the snout. The fourth and fifth gill-openings approximated to each other.

Pristidophorus, Miill. \& Henle, Mag. Nat. Hist. ii. 1838. Plagiost. 98.

Scymui, part, Mïll. \& Ilenle, Plag. 91.

Pristis, sp., Lath. Limn. Trans. ij. 282. Cuv. Rég. An. 2 ed. ii. 394 .

1. Pristiopholus cirratus. 'Tentaculated Saw-fish.

Pristiophorus cirratus, Mïll. \&. Henle, Plag. 98.

Squalus tentaculatus, Shaw, Nat. Misc. 630.

Pristis cirratus, Lath. Liun. Trans, ii. t. 26, f. 5, t. 27.

Squalus anisodon, Lacép. iv. 679. Cuv. Règ. An. 2 ed. ii. 395.

Haв.-Australasian Seas, Japan.

a. In spirits. Japan. From Mr. Frank's collection.

$b$-d. Stuffed. Van Diemen's Land. Presented by R. Gunı, Esq.

$e$. Stufled.

f. Rostrum. New Holland. Presented by General Hardwicke.

g. Rostrum.

\section{PRISTIS.}

The teeth of the saw in all respects alike, flat and cutting, pretty straight, directed outwards; they begin just before the nostrils. Nostrils far before the mouth. A long and three-cornered flap on the upper border: on the under border merely a ledge-like flap. Corner cartilages of the mouth wauting. Moutl cross and straight. Velum on the upper-jaw, with a straight edge. Teeth flat, parement-like. The upper eyelid without projection. Spont-holes large, divided from the eyes by a broarl bridge. First back-fin some way above the belly-fins. Both back-fins equally large. 'The tail-fin shert, with or without an under lobe.

Pristis, Lath. Limn. Trans. ii. 282. Cur. Règ. An. 2 ed. ii. 394. Miill. \&. Itenle, May. Nat. II ist. ii. 89, 1838, Plagiost. 105. Pristobatus, Blaine. Bull. Soc. Phil. 121. 


\section{Pristis antiquorum.}

Pristis antiquorum, Lath. Linn. Trans. ii. t. 26, f. 1. Müll. \&. Henle, Plag. 105. Lim. Faun. Suec. Retz.307. Cur. Rèy. An. 2 ed. ii. 394. Bluiv. Fann. Fr. 50. Agassiz, ii. t. G, t.

4. De Kay, Nat. Hist. of New York, 365, 1842.

Serra marina, Bclon. 66.

Serra, Gesn. 728.

Pristis, Aldrov. 694. Mus. Berl. t. 17. Jonst. t. 4, f. 1. (Copied in Ruysch, Thes. t. 5, f. 1). Mus. Worm, 285. Gottorf. K'unstk. t. 25, f. 1. Willonghby, 61, t. B, 9. f. 5. Clus. Exot.

136, t. 14. Knorr. Delic. 56, t. ii. 4, f. 4.

Araguaguan, Marcgr. 151.

Priste o sega, Mose. 227.

Spadon, Dutertre, ii. 195, f. 208. Blasins, Anat. t. 49, f. 13.

Serra piscis, Vulent. Mus. i. 488.

Pristis s. serra piscis, Ray, $S y m .23,16$.

Galeus rostro longo, plano, frmo, Klein, Wisc. Pisc. iii. 12, f. $1,2$.

Squalus rostro cuspidato, osseo, plano, utrinque dentato, Gronor. Mus. i. 132. Zooph. 33, 148.

Schwertfisch, Pontop. 290, tab. ad pag. 285.

Squalus pristis, Linn. Gm. 1499, 15. Mus. Ad. Frid. 52. Forsk. Descr. 10. Muill. Prod. 38, 319. Duhamel, pl. 25, f. 3-5. Fabric. Faun. Grenl. 130,91. Bloch, Schneid.1. 120.

Piscis serra, Bonn. Mus. Kirch. 155, t. 37, f. 21.

La Scie, Brouss. 671, 20. Encycl. f. 24.

Pez de Esparla, Parra. 75.

Pristis serru, Bloch, Schneid. t. 70.

Pristis granulosa, Bloch, Schneil. 351.

Pristis caniculata, Bloch, Schneid. 351.

? Squalus, No. 1, Browne, Jam. 458.

Squalus rostro longo cuspidato usseo, plano utrinque dentato, Artedi, Gen. Pisc. 504.

Squale Scie, Lacép. i. 286, pl. 8, f. 4.

Seie commune, Dict. Sei. Nat. 27.

Saw-fish, Peun. Suppl. 105.

Hab.-Mediterranean, Ocean.

a. Stuffed.

b. Stuffecl. Indian Seas. From Dr. A. Smith's collection.

c. Rostrum. (53 in. length, $10 \frac{1}{4}$ in. breadth).

d. Rostrum. India. Presented by T. E.J. Boileau, Esq. $e, f$. Rustrum. 
g. Rostrum.

$h, i$. Rostrum. West Indies. From IIr. Scrivener's collection. j. Rostrum. Tenasserim. Presented by J. I). C. Packman, Esq. $k-n$. Rostrum.

o. Rostrum. Young.

\section{Pristis pecrinatus.}

Pristis pectinatus, Lath. Mïll. y. Henle, Plag. 109. Lath.l.c. t.

2. Risso, Hist. Nat. iii. 141. Cur. Rè̀y. An. 2 ed. ii. 394.

Pristis pectinata, Bloch, Schneid. 351. Blainv. Faun. Fr. 51. Over, Odontl. t. s, f. 1.

Squalus pectinatus, IIumiltom, 5.

Has,-Atlantic Ocean, South Sea.

a. Stuffed. Mexico. From Mr. Warwick's collection.

b. Stuffed. West Indies. From Mr. Scrivener's collection.

c. Stuffed. Cape. From Mr. Warwick's collection.

d. Rostrum (52 in. length, 5l ill. brealth). Presented by Miss Pepper.

e-g. Rostrum.

h. Rostrum, with part of the skull. Presented by Edwin Keele, Esiq.

$i-k$. Rostrum. Young.

l. Sutufied.

m. Stuffed. Calcutta. Presented by E. Blyth, Esq.

$n$. Rostrum.

3. Pristis Microdon.

Pristis mierodon, Lath. Mïll. f. Henle, Plag. 107. Lath.l.c. t. 26, f. 4. Bloch, Schneid.351. Cur. Règ. An. 2 ed. ii. 394. HaB.-India.

4. I'ristis cuspidatus.

Pristis cuspidatus, Lath. Mïll. \&. IIenle, Plag. 107. Lath. I. є. t. 26, f. 3. Bloch, Sclneill. 351. ('ux. Rég. Ar. 2 ed. ii. 394. ? Pristis, Valent. Amboina, t. 52, f. Y.

Hib.

a. Rostrum. Tenasserim. Presented by J. D. C. Packman, Esı. 
5. Pristis semisagititus.

Pristis semisagittatus, Shaw, Gen. Zool. 361. Mïll. \&. IIenle, Plag. 108. C'w. Rig. 1n. 2 ed. ii. 394. IIardw. Icon. ined. 60.

Yahli, Russell, j. t. 13.

HAB.-Coromandel.

a. Stuffed. India. Presented by T. E. J. Boileat, Esq.

b. Animal in a dry state.

c. Rostrum.

d. Rustrum. From Dr. Mantell's collection.

6. Pristis Perotetet.

Pristis Perotteti, Valenc. MSS. in Miill. Y. Itenle, Plag. 108. HaE.-Senegral.

\section{Fam. 5. RAID.E.}

Body much depressed, broad, abruptly ending in a slender tail. Raja, Cur. Rig. In. 2 edl, ii. 395. Squatinorair, part, Miill. F. Henle, Plag. Torpedines, Miill. t. Henle, Pluy. Raide, Suains. Cib. Cyd. 319, 1×37.

1. The fore part of the body forms, through the conjunetion of the breast-fins with the snont, a disk. The breast-fins fomr-comered separated from the head portion of the disk by a noteh, not reaching the belly-fins. Firnt back-lins above the belly-fins. Tail-fin twolobed, with the upper lobe a little larger. The side keels are continued along the tail-fin. Mouth undulated. Three protuberances of the under-jaw correspond with an equal number of depressions in the upper-jaw. The teetlu are longer on the summit of tbe mudnlations. Nostrils slit lengthways near the mouth, with a flap above and below The mpper one stands out iu two parts, one outer, more slender, and longer rounded lobe, and one inuer shorter and broader, which are separated firm one atnother by a notch more or less deep.--Rhwis.

Rhinæ, Miill. \& Itenle, Plag. 110.

Rhinubatis (\$ a), Miill. F. Henle, May. Nat. Hist. ii. 89, $183 \pi$.

Rhinobatinæ, part, Swains. Cab. Cycl. 317, 1837. 


\section{RHINA.}

Snont rounded before. Spout-loles close behind the eyes. The upper and nuler nasal-flaps reach up to the inner corner of the nustril. The undulation of the moutls very bold. The teeth almust round, not broader than long.

Rhina, Bloch, Schneid. 72. Cuv. Règ. An. 2 el. ii. 396. Miill. \&. IIenle, Mag. Nat. Mist. ii. 89, 1828. Plagiost. 110. Bonap. Seluc. Tab. Anal. Swains. Cab. C'ycl. 319 (not Rafin.)

\section{Rinina ancyclostonus.}

Rhina ancrclostomus, Bloch, Schneid. 352, t. 72. Cuv. Règ. An. 2 ed. ii. 396. Agassiz, t. H, f. 3, 4. Gray \& Hard. Illust. 102, f. 2. Müll. \& Hente, Play. 110. Öven, Odontl. t. 33 (teeth). Rich. Rep. Brit. Assoc. 195, 1845.

HsB.-Indian Ocean.

a. Stuffed. Adult. Madras. Presented by T. C. Jerdon, Esq

b. Stuffed. Young. China. Presented by J. R. Reeves, Esq. c. Teeth. Adult. Penang. Presented by Dr. Theodore Cantor.

\section{RHY NCHOBATUS.}

Snout clongated, pointed with a keel in the middle, which tapers gently forward. The space between the keel and the inner edge of the breast-fon is composed of skin. Spout-holes immediately behind the eyes. Upper eyelid with a simple projection. The upper and under nasal-flaps do not reach np to the inner corner of the nostril, but only up to half of them ; on the outside of the same on the up. per edge of the nostril a narrower ledge. The undulations of the mouth feeble, particularly the side ones. Teeth broader than long, with a transverse wreath. A transverse arched row of pores un the ventral sile of the seapular chain.

Rhynchobatus, Mrill. \&. Henle, Mug. Nat. Hist. ii. 89, 1838.

Playiost. 111. Bonap. Seluc. Tab. Anal.

Rhinubatus (§ 1), Cur. Rég. An. 2 ed. ii. 396.

\section{Rhynchobates LeVIS.}

Rhynchohatus lievis, Mïll. J. Henle, Plag. 111.

Rhinobatus, Duham. sect. 9, pl. 15. 
Rhinobatus Djeddensis, Forsk. Descr. 18. Livn. Gm. 1511.

Rhinobate, Lacép. i. pl. 6.

Raie bohkat, Lacép. i. 139.

Rhinobate lævis, Bloch, Schneid. t. 71.

IValawah Tenkee, Russell, 10.

Rhinobate lisse, Dict. Sci. Nat. 19.

Rhinobatus lævis, Cuv. Reg. An. 2 ed. ii. 396.

Rhinubatus Djeddensis, Riipp. Alt. 54, t. 13, f. 1. Benn. Life of Raffles, 693.

Rhinobatus Duhamelii, Blainv. Faun. Fr. 148.

a. Indian Seas?

b. Stuffed. Red Sea. From Dr. Rüppell's collection. Rhinobatus Djeddensis, Riippell.

c. India. Young. Presented by T. E. J. Boileau, Esq.

2. The belly-fins begin immerliately behind the attachment of the breast-fins; these pass imperceptibly into the snout. Both back-fins upou the hinder part of the tail of equal size. The belly-fins are four-cornered, longer than broad, rounded before, pointed behind. Tail-fin without an under lobe. The keels of the tail begin behind the belly-fins, and pass on converging to the under edge of the tailfin. Month straight, transverse or gently arched forwards. Teeth parement-like, flat, with a more or less sharp cross ledge. Spoutholes close behind the eyes. A row of pores beueath the scapular girdle.-Rhin оватімa.

Rhinobatis (§ B), Miill. \& Henle, Mag. Nat. Hist. ii. 89, 1838.

Rhinobatides, Müll. \&. Henle, Play.

Rhinobatus ( $\$ 2)$, Cun. Rey. An. ? ed. ii. 396.

Rhinobatinæ, part, Swains. Cab. Cycl. 319, 1839.

\section{RHINOBATUS.}

The skull is prolonged forwards into a keel; the interspaces betwixt it and the inner borders of the breast-fins are cuticular. Snout more or less sharp. The upper nasal-flap consists, as in Rhinchobatus, of an onter, more slender and louger, and an inner, broader and shorter lappet. The outer lappet is slender, but reaches with its rounded point up to the under margin of the nostril, and is not sharply divided from the inner lappet; the outer lappet is nearly in the middle of the upper edge of the nostril; the inner one extends more or less widely inwards. Spout-holes and eyes encompassed by a common wall of skin. The upper eyelid has a middle 
arnate projection; the upper velum with its indented edge is curved inwards in the middle. 'The fore lateral edge of the disk is twice gently incurved.

Rhinohatus (\$ 2), Cur. Rig. An. 2 ed. ii. 396. Miill. \&. Henle, Mag. Nat. Hist. ii. \$9, 1838. Plagiost.

Rhinobates, Suains. Cáb. Cycl. ii. 319, 1839.

Rhinobatus aut Raji squali, Blainv. Bull. Soc. Phil. 121, 1816. Jour.de Phys. 262, 1816.

* 'The upper nasal-flap reaches inwards over the inner border of the nostril without attaching itself iu the middle.-SYrRHINa.

Rhinobatus (§ 1), Syrrhina, Miill. \&. Henle, Plag. 43. Bonap. Selac. Tab. Anal.

1. Rhinomatus (Syrrhina) Coltuma.

Rhinohatus (Syrrhina) Columna, Wiill. f. Henle, Plag. 113.

Rhinobatus s. Squatino-Raja, Columma, Phytobas. t. 27.

in Willonghby, D. 5, f. 1). Ray, 28, 12.

(Copied

Raja rostrata. Shaw, Nat. Misc. 173. (not Banks).

Rhinobatus Columne, Bomz. Sclac. Tab. Anal. 14, 1838.

$\mathrm{H}_{\text {A B.-Mediterrauean, Sicily. }}$

a. Stuffed. Mediterranean?

2. Rhinobatus (SrrRhina) brevitostris.

Rhinobatus (Syrrhina) brevirostris, Miill. S. Henle, Plag. 114.

HAB.-Brazil.

3. Rhinobatus (Srrrina) Blochil.

Rhiuobatus (Syrrhina) Blochii, Miill. f. Henle, Plag. 115.

H.ib.-Cape.

a. In spirits. Cape of Good Hope.

4. Rhinobatus (Srmmina) axiulatus.

Rhinobatus (Syrrhina) annulatus, Snith, MSS. Illust. Afr. Zool.

Pisc. pl. xvi. 18, 1849. Miill. \&. Henle, Plag. $116,1841$.

His.-Cine.

a. Stuffed. Cape Seas. Presented by Dr. A. Smith. 
5. Reivobatus (Syrruina) Bougainvillit.

Rhinobatus (Syrrhina) Bougainvillii, Valenc. MSS. Mrill. \& Henle, Play. 117. $\mathrm{H}$ \& $\mathrm{B}$.

6. Rhinobates (Syrritina) Banksh.

Rhinobatus (Syrrhina) Banksii, Miill. f. Henle, Plag. 123. Raja rostrata, Banks, M.S. Brit. Mus. 45. Hab.-New Holland.

** The upper nasal-flap does not reach to the inner angle of the nostril-Rilnobatus.

Rhinobatus, Miill. \&. Henle, Plag. 117.

7. Rhinobatus granulates.

Rhinobatus Rhinobatus, Bloch, Schneid. 353.

Rhinobatus gramulatus, C'ur. Rég. An.2 ed. 396. Müll. t. Henle, Plag. 117.

$\mathrm{H}_{\mathrm{AB}}$.-Indian Ocean.

a. Stuffer. Adult.

$b, c$. Stuffed. Young. Mediterranean? From Mr. Argent's collection.

d. Stuffed. India. Presented by T. E. J. Boileau, Esq.

8. Rinimobatus Halavi.

Raja Halavi, Forsk. 19, n. 18.

Rhinobatus Halavi, Rüpp. Atl. 55, t. 14, f. 2. Müll. \& Henle, Play. 120.

Rhinobatus Thouini, var.? C'ur. Règ. An. 2 ed. ii. 396.

HAR.-Indian Ocean.

a. Stuffed. China.

b. Stuffed. Red Sea. From Dr. Rüppell's collection.

c. Stuffed.

d. In spirits. India. Presented by Gen. Hardwicke. 
9. Riminobatus cyimellus.

Raja Rhinobatus, Shau, Gen. Zool.:317.

Rhinobatus cemiculus, Geffroy, St. Hill. Deser. Ey. 339, pl. 27, f. 3. Müll. f. Henle, Plag. 118.

Hals.-Mediterranean.

10. Rhivobites Philippi.

Rhinobatus Philippi, Mïll. f. Henle, Plag. 119.

H.iB.-Ocean.

\section{Rhinobatús armates.}

Rhinobatus armatus, Gray \&. Hardx. Illustr. 99. Miell. \&. Henle, Plag. 119.

Rhinobatus typus, Benn. Life of Ruffles, 694.

HAB.-India.

12. Rhinobatus Thouni.

Rhinobatus Thouni, Miill. f. Henle, Plag. 120.

Rilje Thoun, Lacép. i. t. 1, f. 3-5. (Copied in Shane, Gen. Zool. 318, t. 147).

HAB.

13. Rhinopatus undulatus.

Puraque, Maregr. 151. (Copied in Milloughby, t. D, 5, f. 2). Ruyseh, Thes. t. 36, f. 9.

Puraque, Lib. Prine. Bruz. Natury. i. 394.

Rhinobatus electricus, Bloch, Schneid. 350.

Torpedo americana, Ray, $S y n .29,2$.

Rhinohatus glauenstictus, Olfers, Torp. 22.

Rhinobatus undulatus, Olfers, Torp. 2:2. Miill. \& Henle, Plag. 121.

Rhinobatus Miarcgravii, Henle, Narc. 34.

HAB.-Rio Janiero, Bahia. 
14. Rhinobatus obtusus.

Rhinobatus obtusus, Miill. \& Henle, Plag. 122.

HAB.-India.

a. Stuffed. Cape Seas. From Dr. A. Smith's collection.

15. Rhinobatus Horkelt.

Rhinobatus Horkeli, Miill. \& Henle, Plag. 122.

HAB.-Brazil.

16. Rhinobates Schlegeliy.

Rhinobatus Schlegelii, Müll. \& Henle, Plag. 123. Rich. Rep. Brit. Assoc. 195, 1845.

$\mathrm{H}_{\mathrm{AB}}$,-Japan.

a. Stuffed. Japan. From Mr. Frank's collection.

\section{Rhinobatus hynnicephalus.}

Rhinobatus hynnicephalus, Rich. Rep. Brit. Assoc. 195, 1845. Hard. Cart. 63.

HAB.-China Seas.

\section{Doubtful Rhinobati.}

1. Squatoraja, Belon. 78.

2. Squatoraja s. Rlinobatus, Aldrov. 477, 478. (Copied in Jonston, Hist. Nat. t. xii. f. 6.

3. Raja dorso dipterygeo, Gronov. Zooph. 36, n. 136.

4. Rayon, Cornide, 126.

5. Sutti vara, Russell, Ind. t. 11. (See Cuv. Règ. An. 2 ed. ii. 396.

\section{TRYGONORHINA.}

Form of the body, suout, teeth, velum, and all other proportions of Rhinobatus. Only the nasal-flaps are different. The two upper nasal-flaps pass over into one another through a common, straight under border; the simple flap hangs down upon the mouth as in 
Trygon, and leaves only the outer angle of the nostril as a round, free opening. The adnate upper eyelid has a crescentic edge. The fore edge of the disk is once incurved.

Trygonorhina, Miill. \& IIenle, Mag. Nat. Hist. ii. 90, 1838. Plagiost. 124.

\section{Trigoxorhina fasciata.}

haja fasciata, Bunks, MS. Icon. ined. 47. Trigonorhina fasciata, Miill. \&. Henle, Plag. 124.

HAB.-Australasian Seas.

a. Stuffed. S. Australia. Presented by the Earl of Derby.

b. Stuffed. From Mr. Argent's collection.

\section{PLATYRHINA.}

The breast-fins approach each other on the point of the snout. The fore end of the skull is grasped by the points of the breast-fius. The tail is thinner than in the other Rhinobatides. All the fins are rounded. The upper nasal-flap is a three-cornered lappet, and stretches inwards above the inner angle of the nostril. The fore edge of the disk is not incurved. The upper eyelid as in Rhinobatus. No roll at the spout-holes.

Platyrhina, Mïll. \&. Henle, Mag. Nat. Hist. ii. 90, 1838. Plagiost. 125.

Torpedo, sp., Cuv. Règ. An. 2 ed. ii. 396, 397.

\section{Platitrhina sinengis.}

Raie chinoise, Lacép. i. 2, t. 2. Hardw. Icon. ined. 74.

Platyrhina sinensis, Müll. \&. Ilenle, Plag. 125. Rich. Rep. Brit. Assoc. pl. 96, 1845.

Rhina anglostoma, part, Bloch, Schneid. 72.

Torpedo, sp., Cuv. Règ. An. 2 ed. ii. 396, 399.

Har.-Japau, China.

a. Stuffed. "Brazil."?

2. Platyrina Schendenit.

Platyrhina Sehœnlenii, Miill. \&. Henlc, Plag. 125.

HAB.- - India. 
2. The baek is rounded, naked, without scales or prickles. The belly-fins stand directly behind the pectorals. The tail short, Aleshy, depressed at the base, cylindrical at the end; with two, one, or no back-fin, and a terminal three-cornered tail-fin. A more or less long euticular keel of skin on each side of the tail. The upper eyelid adnate withont a projection. The nasal flaps on both sides are attaelied to a four-sided lobe with a free edge, which leares only the outer engle of the nostril mugirt, and is comnected by a band to the npper lip. Teeth pointer or flat. An electrieal apparatus of upright little pillars, whose flat curls shine through the skin of the back and belly between the head, gills and inner edge of the breast fins.-TORPEDININA.

Torpedines, Miill. f. Henle, Mag. Nat. Hist. 1838,90. Plagiost. 126.

Torpedo, Cur. Rèy. An. 2 ed. ii. 396.

Torpedinæ, Swains. Cab. Cycl. ii, 319, 1834.

\section{† Tun back-fins.}

\section{TORPEDO.}

Disk rounded, truncated before, straight or somewhat incurved. Mouth crescentie, the teeth are pointed, attaelied to a jaw cartilase and not extending outwards beyond the margin of the mouth. Their hase is longest transverscly. The bridle of the nasal-flay springs from the middle of the edge of the upper lip. The eves are remote from the spont-holes. A cornice of enticular tecth on the brink of the spont-lole. The belly-fins rounded. Two baek-fins, the first larger than the second; and the first above the hinder part of the belly-fins, the sceond in the midclle between the first and tail-fin. Tail-fin three-comerch, with a straight hinder edge.

Torpedo, Dum. Zool. Anal. 1806. Cme. Rèy. An. 2cel. ii. 396. Miill. \&. Mcnle, Mag. Nat. Mist. 1838, 90. Plagiost. 12ti. Swains. Cab. Ciycl. ii. 319.

Narcohatus aut Raja torpedinus, Blaine. Bull. Soc. Phil. 1sit, 121.

\section{Torpedo oculata.}

Torpedo oculata, Belon. 93. Mïll. \&. Ilenle, Plag. 127. Torpedo, Rondelet. 358, 362, a. (Copied in Ruyseh, Thes. i. t. 9, f. 3. Kolbe, Cap de Bonne Esp. t. 8, f. 6, 7. Gesner, 
989, 990. Jonston, 9, f. 3, 4). Salviani, t. 48. (Copried in Ruysch, Thes. i. t. 9, f. 4.-Aldrov. 417. Kolbe, t. 8, f. 6. Willoughby, t. D. 4. Jonston, t. 9, f. 4). Matthiolus, Comment. 189. Besler, Fascic. t. 6. Mus. t. 16. Ray, 28, 1.

Torpedine, Lorenzini Osserv. t. 1, f. 1

Tremielga, Cornide, Ens. 123.

Raja 'Torpedo, Bloch, 122. (Copied in Buffom, Hist. Poiss. 9, p. 42). Blum. Nat. Geg. Heft. 6, t. 57.

Torpedo ocellata, Raf. Ind.60. App. gen. 20, spec. 29. Rudolphi, Phys. i. 199. V. Olfers, Torp. 9, t. 1, f.3. Henle, Narc. 30. Torpedo maculata, Raf. Ind. n. 381 .

Torpedo variegata, Raf. Ind. n. 382.

Raie Torpille, Geoff. Ann. du Mus. i. 392, t. 26, f. 1.

Torpedo Narke, Risso, Ichth. 18. Hist. Nat. iii. 142. Cuv. Règ. An.

2 ed. ii. 396. Bonap. Faun. Ital. fase. 14, f. 1, 2.

Torpedo unimaculata, Risso, Ichth. 19, t. 3, f. 3. Hist. Nat. t. 3, 143, f. 8.

Torpille à une tâche, Dict. Sci. Nat. t. 21. (Copicd from Risso T. unimaculata).

Torpedo oculata, Davy, Researches, i. 78.

HaB.-Mediterranean.

a. Stuffed.

$b$. Stuffed.

c. In spirits. Dalmatia. From Dr. Heckle's collection.

d. In spirits. Mediterranean. From Mr. Frank's collection.

\section{TORPEDO NOBILIANA.}

Torpedo nobiliana, Bonap. fasc. 12, 1835. Miill. \& Henle, Plag. 128. Yarr. Brit. Fish. 2 ed. ii. 546, 1841.

Torpedu Walshii, Thomp. Amn. Nat. Hist.v. 292. Faun. Ireland, Vert.

Torpedo emarginata, MCoy, Ann. Nat. Hist. vi. 407?

HAB.-Mediterranean.

\section{TORPEDO MaRMORATA.}

Narce, Torpedo, Bélon. 90, 91. (Cupied in Gesner, 988). Rondelet. 362, 363. (Copied in Ruysch, Thes. i. t. 9, f. 3, 5. Gesner, 991. Jonston, 9, f. 3, 5). Gesuer, 992. Aldrov. 418. Walsh, Phil. Trans. 1772, lxiii. 480, f. 1-3. (Copied in Langguth, Opusc. t. iii.) 
Torpille, Réaum. Mem. de l'Acad.344. Duhamel, sect.9, 13.

Raja Torpedo, Brunnich, i. n. 1.

Raja maculata et bicolor, Shaw, Gen. Zool. vii. 16.

Torpedo immaculata, Raf. Ind. 60, 30.

Torpedo punctata, Raf. Ind. 61, 31.

Torpedo marmorata, Risso, Ichth. 20, 3, t. 3, f. 4. Hist. Nat. 143, 28, f. 9 . (Copied in Diel. Sei. Nat. t. 21, f. 2). Miill. 5. Henle, Plag. 128. Rudolph. Phys. i. 199. Olfers, Torp. 14. Henle, Nare. 30.

Torpedo Galvanii, Risso, Ichth. 21, 11. 23, t. 3, f. 5. Hist. Nat.

144, 29. Bomap. Faum. Ital. fasc. 3-5.

? Torpedo siuns persici, Kaempfer. Amen. Exot. 509.

? Temeree et Nallah Temeree, Russell, i. 2, t. 2.

HAB.-Mediterranean.

a. In spirits. (Bleached).

b. Stuffed. From Mr. Leadbeater's collection.

c. Stufferl. Mediterranean. From Mr. Argent's collection.

d. Stuffed.

e. Stuffed.

$f$. In spirits.

\section{Torpedo panthera.}

Torpedo panthera, Erhrenb. Müll.\&.Henle, Plag. 193. Ehrenb. in Olfers, Torp. 15, 16. Rïipp. Chondropt. 8, t. 19, f. 1.

$\mathrm{H}_{\mathrm{AB}}$,- - Red Sea.

\section{NARCINE.}

Disk roundish, elliptical or angular, rounded before, provided with a broad keel. Mouth small, protruding forwards, surroumded by a circular fold of skin, which passes above into the bridle of the nasal flap. Nasal flat straight, with a middle projection, sometimes lengthened a little sideways, so as to become three-tipped. A labial cartilage above and below. 'Teeth in quincuncial order, with a middle point; and arranged on the borler of the jaw so as to form outwards an elliptical plate. The skin which supports them is not adnate to the jaw, but is capable of slirling upon it. A relum behind the upper jaw. Tail longer than the disk. The first backfin behind the belly-fin, smaller than the second. Spout-holes close behind the eyes. Margin of the spout-lioles without teeth.

Narcine, Henle, Narc. Müll. \&. Henle, Mag. Nat. Hist. 1838, 90. Plagiosl. 129. 
1. Narcine bmasilifisis.

Raja dorso dipterygio, caudit brevi, apice pinnato, Gronov. Zooph. fase. i. 35,153, t. 9, f. 3 .

Torpedo ocellata, Quoy \&. Gaim. Freyc. 199.

Torpedo brisilicusis, Olfers, Torp. 19.

Nareine brasiliensis, Henle, Nare. 31, t. 1. Müll. \& Henle, Plag. 1:29.

Torpedo Bancroftii, Griff. An. Kingd. pl. 34.

Hab.-Brazil (Rio de Janeiro), Cape.

a. Stuffed.

$b$. Stuffed. West Indies. From Mr. Scrivener's collection.

c. In spirits. Young. Parà. From Mr. Bates' collection.

2. Narcine indica.

Narcine indica, Henle, Narc. 35, t. 2, 1. 2. Müll. \&. Henle, Play. 130.

Hsв.-Tranquebar.

\section{Narcine Livglita.}

Narcine lingula, Rich. Rep. Brit. Assoc. 196, 1845, Reeves, Icon. ined. 227. Hardw. Icon. ined. Cart. 72.

HAB.-China Seas. Madras.

\section{Narcine Timlet.}

Turpedo Timlei, Bloch, Schneid. 359. Cuv. Règ. An. 2 ed. ii. 397. Narcine Timlei, Henle, Narc. 34, t. 2, f. 1. Müll. \&. Henle, Plag. 130. Rich. Rep. Brit. Assoc. 196, 1845.

HAB.-Clina Seas.

$a, b$. In spirits. China Sears. Presented by Sir J. Richardson, M.D.

\section{Narcine tasmaniensis.}

Narcine Tasmaniensis, Rich. Proc. Zool. Soc. March, 1840. Ann. Mag. Nat. Hist. 310, 1840.

HaB.-Anstralian Seas.

a. In Spirits. Tasmania. Presented by Sir J. Richardson, M.D. 
†† One back-fin.

\section{ASTRAPE.}

Snout short, without a keel. Month in many respects as in Narcine. The bridle of the nasal-flap provided with a cylindrical cartilage. The teeth pointed on a four-comered base, pass the edge of the jaw, but a little outwards. Telum on the upper and lower jaw. The single back-fin and the tail-fin rounded. Eyes and spout-holes approximated to each other. Spout-holes smooth.

Astrape, Miill. F. Henle, May. Nat. Hist. 1838, 90. Plagiost. 130. Narcine, sp. Itenle, Narc. 36.

\section{Astrape capensis.}

Raja dorso monopterygio, Gronov. Zonph. fasc. i. 35, n. 152.

Rajia capensis, Lim.Gm. 1512. Bloch, Sichneid. 360.

Torpedo capensis, Olfers, Torp. 23.

Narcine eapensis, Henle, Narc. 36, t. 3, 1. 1. Astrape capensis, Hiill. \&. Henle, Play. 130.

Haв.-Cape.

2. Astrape DIPTERYgia.

Raja dipterygia, Bloch, sichneid. 359.

Torpedo dipterygia, olf. Torp. 2.5.

Narcine dipterygia, Henle, 38, t. 3, f. 2.

Astrape dipterygia, Hiell. F. Henlc, Plu!. $13 \mathrm{I}$.

HAB.-Tranquebar.

\section{十†+Nobacli-fin. \\ 4. TEMERA.}

Nose, month, velum as in Astrape. Tail without a batk-fin, in proportion to the dish short. Spout-lioles close hehind the eyes, without teeth; flat teeth.

'Temera, Gray, Zool. Misc.7. Illustr. Ind.Zool.t. Hïll. \&. Henle, Mag. Nat. Hist. 1838, 90. Plagiost. 131. Swains. Cab. C'ycl. ii. 319. 


\section{Temera Hardwickil.}

Temera Hardwickii, Gray, Zool. Misc. 7. Gray \& Hardw. Illustr. 102, f. 1. Miill. \&. Henle, Plag. 131.

Has.-Penang.

a. In spirits. Penang. Presented by Gen. Hardwicke.

4. The breast-fins cohere jointly to the snout, and their attachments reach to the belly-fins. The disk is broad and rhomboidal. The tail is thimner in proportion to the body than the foregoing, the two back-fins are removed quite towards the point; the terminal-fin exists merely as a ledge at the end of the tail, or is entirely wanting. 'The tail is depressed, and has a keel of skin on eacli side throughout its whole length. 'The upper cyelid adnate. Eyes and spout-holes separated only by a slender bridge. Syoutholes with smooth edges. The four-sided lappet formed out of the pouting nasal-flap is adnate by its whole under edge to the dental margiu of the upper jaw; only a small part of the under edge remains free on each side, which passes into the lateral margin br a rounded angle, and is mure or less deeply fringed. On the outer termination of the nostril a small cuticular ledge. Mouth arched forwards, without labial cartilages, teeth pointed or parement-like, flat, in the males pointed in spawning time. Velum in the upper jaw only, notched in the middle, with a fringed edge. The skin is either smooth, or clothed with small, curved prickles, more or less crowded, and directed backwards; among which there arise also bigger spines; the larger spines are most abundant on the ridge of the back and tail, then upon the ridge of the eyes, the keel of the snout, and upon the fore-edge of the breast-fin before the outer corner. In the males, in the spawning season, two sharp spines develope themselves on the fore-edge of the breast-fins. They are the only spawning Rays.-R.il.E.

Raja, Cuv. Règ. An. 2 ed. ii. 397.

Raiz, Miill. \& Henle, Mag. Nat. Hist. 1838, 90. Plagiost. 132. Raidæ, Trigoninæ part, Swains, Cab. C'ycl, ii. 319.

\section{RAJA.}

The snout is prolonged into a keel, the inner edges of the breastfins are parallel to the keel. The interspace between the keel and the inner edges of the breast-fins is cuticular. The belly-fins divide 
into an inner and outer lobe by a deep notch on the hinder edge. The outer lobe is thicker than the inner one, but more slender. The tail has a low terminal fin, more conspicuous on the upper side than on the under one; it is for the most part intermpted at the point.

Raja, Lim. Mïll. \&. Henle. Mag. Nat. Hist. 1838, 90. Plagiost. 138. Swains. Cab. C'ycl. ii. 319.

Dasybatus, part, Klein.

Dasybatus, Blainv. Bull. Soc. Phil. 1816, 121.

Dipturus (batis) Rafin. Caratt. 1810.

Læviraga, Belon. Nardo.

Propleygia, Otto. Is founded on a monstrosity rather frequent among the Rays.

* Snout blunt. The keel does not project on the fore edge of the disk.

1. Raja Radula. Sandy Ray.

Raja radula, De la Roche, Ann. du Mus. xiii. 321. Müll. \&. Ifenle, Plag. 133. Risso, Hist. Nat. iii. 151. Cuv. Règ. An. 2 ed. ii. 398. Bonap fasc. 13.

Raja virgata, Geoff. St. Hil. Descr. Eg.337, 26, f. 2, 3.

Raia spinosa, Rond. 355 .

Raja falsavela, Bonap. fasc. 26.

Raie ratissoire, Blainv. Fann. Fr. 25.

Sandy Ray, Couch, Mag. Nat. Hist. ii. 71. Yarr. ii. 574, 1841.

Raia circularis, Couch, Mag. Nat. Hist. xi. 71. Corn. Faun. 63.

Hıв.-Mediterranean, English Channel.

a. Stuffed. Plymouth. Lieut. H. F. Spence, R.X.

2. RAJA ATRA.

Raja atra, Mill. \&. Henle, Plag. 134.

$\mathrm{H}_{\mathrm{AB}}$,- Sicily.

\section{Raja undelata.}

Raja undulata, Rond. 346? Lacep. iv. pl. 14, f. 2. (Copied in Shaw, Gen. Zool. 280, t. 140). Miill. \& Henle, Plag. 134. Cuv. Règ. An. 2 ed. ii. 398.

Dasybatus, No. 11, Klein, Misc. Pise. iii. 36.

Dasybatus, No. 12, Klein, Misc. Pisc. iii. 37. 
Raja picta, Lacep. iv. 675, pl.16, f. 2. (Copied in Shaw, 279, t. 140 ).

Raja alba, Lacep. r. 636, pl. 20, f. 1. (Copied in Shaw, 280, t. 139).

Raja mosaica, Risso, II ist. Nat. iii. 154. Blaint. Fam. Fr. 32, pl. 4, f. 2 .

Raja fenestrata, Rafin. Caratt. 15, 36.

Raja maderensis, Loue, Trans. Zool. Soc. Lond. ii. 1839, 195.

HAB,-Mediterranean.

* Snout pointed, more or less elongated.

4. Raja clavats. Thornback.

Raja, Belon. 80 .

Raja clavata, Rond. 353, 354. (Copied in Ruysch, Thes. t. ii. f. 3). Aldrov. 461. Müll. \&. Henle, Plag. 135. Gesner, 943. Aldrov. 459. (Copied in Ruysch, Thes, to ii. f. 2). Mcchr. Act. Phys. Med. Nat. Cur. ri. 483. Lim. Faun. Suec. 304. Mus. Ad. Frid. 52. Bloch, 83. (Copied in Encycl. pl. iii. f. 9). Bloch, Schneid. 366. Shaw, Gen. Zool. 272, t. 139. Don. 26. Risso, Ichth. 11. Hist. Nat. iii. I46. Flem. 170. Cur. Règ. An. 2 ed. ii. 398. Jenyns, 516. Fries, Arter. af Raja, 15, t. 2, f. i. t. 3, f. 1, 2, 3, 7. Blainv. Faun. Fr. 33, pl. 5, c.f. 2.

Raja lævis s. barattula, Aldror. 450, 451 .

Daspbatus, Nos. 6, 7, Klein, Mise. Pisc. iii. 36.

Thornback, Penn. 93, t. 11, 12. Yarr. 2 ed. ii. 582, 1841.

Raie grise à peau rude, Duham. ii. §. 9, pl. 8, f. 1-4, pl. 9, f. $1-2$.

Raja rubus, Linn. Gmel. 1507. Bloch, 84. (Copied in Encycl. pl.v. f. 11). Blainv: Eaun. Fr. 21.

La raie bouclée, Lacep. t. 1, 128.

Raja aculeata, Artedi, Ichth. v. 103, pl. iii. 525.

Raja punctata, Hollb. Götheb. Nat. Handb. iv. 28.

Squatinoraja clarata, Nardo, n. 10.

Raja aspera, Risso, Ichth.5. Hist. Nat. iii. 147. Cut. Règ. An. 2 ed. ii. 398.

Raja spinosa, Rafin. Ind. 47.

? Raja rubus, Nilis. 118.

Raja poutica, Rathke, Krym. t. iii. 10.

Haв,-European Seas.

a-P. Males. Stuffed. Fritl of Forth. From Dr. Parnell's collection. 
f. Young female. Stufted.

y. Female. Stuffed. English Coast.

$h$. Female. Stuffed.

$i, j$. Young. Stuffed. Plymouth. Prescuted by Lieut. H. F. Spence, R.S.

$k$-n. Young. Stufferd. English Coast.

n. Jaws. From Dr. Mantell's eollection.

p. Jaws. Female.

q. Jaws. Adult female.

$r$. Stuffed. Dalmatia. From Dr. Heekle's eollection.

5. Raja liantita. Starty Ray.

Raja cglantiera, Lesueur, Phil. Ac. iv. 4.

Raja Clavata, Hollb. Giitheb. Nat. Handb. ir. 29. Nils. Prodr. 118.

Raja fullonica, Fabr. F. Grenl. 125.

Raja radiata, Donor, t. 114. Flem. Brit. An. 170. Jenyns, Brit. An.517. Fries, Arter. af Rajar, 21, t. 3, f. 4. Parn. Trans. Edin. Roy. Noc. 1s:39, 145. Parn. Icth. Firth of Forth, 279, 1838. Miill. f Itenle. Play. 133.

Starry Ray, Yarr. Brit. Fish. 2 ed. ii. 439, 585, I\&11.

$\mathrm{H}_{\mathrm{A} B},-$ European Seas.

$a-d$. Stuffed. Frith of Forth. From Dr. Parnell's collection.

6. RAJA verus.

Raja nærus, Miill. 1. Henle, Play. 138.

Raja lalsarela, Bonap. Faun. Ital. lase. 26.

Haв.-European C'oasts of the Atlantic and Mediterranean, rarely.

\section{RHJ Schlitizi.}

Raja Sehultzii, Miill. f. Henle, Plag. 13s.

Raja asterias aut stellati, Belon.

Rija asterias aspera, Romel. 352. (Copied in Ruysch, Thes. 1, t.

10, f. 7). Kolbe, viii. f. 5, n. 1. Altror. $458^{\circ}$.

Dasbatus, No. 5, Klein, Misc. Prsc. iii. 36.

?Raja crabuda, Corride, Ens. I26.

Raja asterias, Risso, Hist. Nat. iii. 153.

Haв.-Mediterranean. 


\section{Raja asterias.}

Lavirija, Belon. 82.

Raja oxyrbynchus, Rond. 347. (Copied in Ruysch, Thes. t. 10, f. 9).

Raja asterias, Rond. 350. (Copied in Aldrov. 457). Mill. \& IIenle, Plag. 139. De la Roche, Ann. du Mus. 13, t. 20, f. 1.

Cur. Règ. An. 2 ed. ii. 398. Blainv. Faun. Fr. 25.

Raja oxvrhyuchus minor, Aldror. 456.

Dasrbatus, No. 4, Klein, Misc. Pise. iii. 35, t. 4.

Dassbatus, No. 13, Klein, Misc. Pisc. iii. 37.

? Raja maculata, Donov. A. A. O. Mont. Wern. Mem. ii. 426. Cur.

Règ. An. 2 ed. ii. 398. Blain. Faun. Fr. 15.

Raja punctata, Risso, Ichth. 12. Hist. Nat. iii. 153.

Raja fullonica, Risso, Hist. Nat. 352.

Læviraja mucosissima, Nardo, A. A. O.

Raja speculum, Blaint. Faun. Fr. 29, pl. iv. f. 1.

$\mathrm{H}_{\star \mathrm{B}}$.-French, English and Italian Coasts. Very common.

a. In spirits. Mauritius.

b. In spirits. Moluceas. From Mr. Frank's collection.

\section{Raja marginata. Bordered Ray.}

Raja marginata, Lacép. г. 663, t. 20, f. 2. (Copied from Shau', Gen. Zool. 281, t. 139). Miill. \& Henle, Play. 140. Flem. Brit. An. 172. Jenyus, Brit. An. 512, sp. 201. Bonap. Faun. Fr. fasc. vi. 19 , t. 3, f. 2 .

Raja rostellata, Risso, Hist. Nat. iii. 148.

Raja bicolor, Risso, Hist. Nat. iii. 155.

The bordered Rav, Yarr. Brit. Fish, 2 ed. ii. 564, 1841.

Raie bordée, Dict. Sci. Nat. t. 20.

HaB.-Mediterranean, North Sea.

a. In spirits. Lyme Regis. Presented by Lord Cole.

\section{RaJa minaletus. Homelyn Ray.}

Læviraja miraletus, Belon. 82. Nardo, A. A. O.

Raja oculata et lævis, Rond. 349. (Copied in Ruysch, Thes. i. t. 10, f. 4). Aldrox. 453.

Raja oculata aspera, Rond. 349. (Copied in Aldrov. 458). Shaw, Gen. Zool. 278, t. 139. Merrett, Pin. Rer. Nat. Brit. 185. 
Raja ocnlata lævis, Ray, 27, n. 9.

Dasybatus, No. 2, 3, Klein, Misc. Pisc. iii. 35.

Raja miraletus, Brun. Ichth. 3, n. 3. Linn. Gmel. n. 4, 1507. Müll. \&. Henle, Plag. 141. Lacép. i. 75. Risso, Ichth. 4. Hist. Nat. iii. 149. Donov. 103. Bonap. fase. iii. Blainr. Faum. Fr. 27, p1. 5, f. 1 .

Raja dorso ventreque glahris, aculeis ad oculos, ternoque eorum ordine in cauda, Artedi, Gen. Pise. 529, n. 7.

Raja rubus, Donov. 20.

Raja biocularis, Geoff. St. Itil. Dese. Eg. pl. 27, f. 2.

Raja quadrimaculata, Risso, Hist. Nat. iii. 150. Bonap. fasc. iii.

Raja oculata, Flem. Brit. An. 172.

Raja maculata, Jenyns, Brit. An. 203.

Homelyn Ray, Yair. Brit. Fish. 2 ed. ii. 429, 570, 1841.

Haв.-European Seas.

a. Stuffed. Firth of Forth, Scotland. From Dr. Parnell's collection.

b. Stuffed. British Channel.

$c$-h. Stuffed. Young. British Channel.

\section{RAJA MICROCELLATA.}

Raja microcellata, Mont. Wern. Mem.430. Jenyns, Brit. An.515, sp. 201. Flem. Brit. An. 171, sp. 23. Miill. F. Henle, Play. 142.

Small-eyed Ray, Yarr. Brit. Fish. 2 ed. ii. 567, 1841.

HaB.-The English Coast.

\section{RaJa Salviani.}

Raja Salviani, Miill. \&. Henle, Plag. 143.

? Raja lævis, Rond. 344.

Læviraja, Salv. 149, t. 52. (Copied in Ruysch, Thes. t. 11, f. (i). Leiobatus, No. 7, Klein, Mise. Pisc. 37.

Raja oxyrhynchus, Brumich, 2, n. 2. Shaw, t. 138. Blaine. Faun. Fr. 18, t. 3, f. 1 .

? Leviraja, Cornide, Ens. 125.

Raja rostrata, Blainv. Faun. Fr. 30, t. 5, a, f. 2.

Læviraja oxyrhynchus et Læviraja macrorhynchus, Bonap. F'anu. Ital. fase. 25 .

Raia mueronata, Yarr. Brit. Fish. 2 ed. ii. 550, 1841.

Raja lævis, De Kay, Nat. Hist. of New York, 370, pt. 1. Znol. 1812.

HAB.-Mediterranean and Atlantic Ocean. 
13. RaJA roMER.

? Raja macrorhynchus, Rafin. Caratt. 15, 38.

Raja vomer, Fries, 36. Miill. f. Henle, Plag. 144.

HAB.-Mediterranean and North European Seas.

14. Raja rullonica. Chagreen Ray.

Raja aspera nostras, Hilloughby, 78. Ray, Syn. 26, n. 5.

Chagreen Ray, Pem. iii. 87, n. 34. Shan, 281.

Raja toto dorso aculeata, Artedi, Gen. Pise. 72, n. 6. Syn. 101, n. 6 .

Raja fullonica, Ascan. t. 43. Null. \&. Henle, Plag. 145. Bloch, Schneid. 36\%. Risso, Ichth. 6*. Fries, 26, t. 2, f. 2.

? La Raie chardon, Lacép. i. 78, t. 1.

La Raie chagrinée, Lacép. i. 81, t. 1.

Raja granulosa, Bloch, Schneid. 368.

Raja chagrina, Mont. Wern. Mem. ii. 420, pl. 2.

Raja flossada, Risso. Hist. Nat. iii. 145.

Raja aspera, Flem. Brit. An. 172, 25.

Raja chagrinea, Jenyns, Brit. An. 513. Parn. Proc. Edin. Roy. Soc. $1839,144$.

Raia fullonica, Yarr. Brit. Fish. 2 ed, ii. 578, 1841.

Hab.-Mediterranean, North, and Scandinarian Seas.

\section{Raja batis. The Skate.}

Raja varia, dorso med. glabro, unico aculeorum ordine in cauda, Artedi, Gen. Pisc. 73, n. 9. Syn. 102, n. 2.

Raja batis, Holb. Gïtheb. Nat. Handb. iii. 21. Nits. Syn. Ichth.

Scand. 120. Risso, Ichth. 3. Mont. Wern. Mem. ii. pt. 2, p. 423. Miill. \& Ilenle, Plag. 146. Jenyns, Brit. An. 510, n.

199. Parn. 1chth. Firth of Forth, 264, 1838. Yarr. Brit. Fish. 2 ed. ii. $561,1841$.

Blue Skate and Giay Skate, Yarr. Brit. Fish. 2 ed. ii. 421.

? Raja batis, Blaine. Faun. Fr. 13, 14.

Dipturus batis, Rafin. Caratt.

Hab.-North Seas, British Seas.

$a, b$. Firtl of Forth, Scotland. From Dr. Parnell's collection. c-e. Young. Firth of Forth, Scotlaud. From Dr. Parnell's collection.

$f-h$. English Coast. 
16. Raja intermedia. Flapper Skate.

Raia intermedia, Parn. Proc. Edin. Roy. Soc. 166, 1837. Trans. Roy. Soc. Edin. xiv. 429, pl. 6, 1839. Mem. Wern. Nat. Hist. Soc. vii. 429, pl. 40. Ichth. Firth of Forth, 269, 1838. Yarr. Brit. Fish. 2 ed. ii.558, 1841. Miull. \&. Henle, Plag.147, 1841. HaB.-British Seas. $a, b$. Stuffed. Firth of Forth, Scotland. From Dr. Parnell's collection.

17. Raja lintea. Sharp-nosed Ray.

Raja lævis undulata seu cinerea, Will. 69 , t. C, n. 5.

Skate, Penn. Brit. Zool. iii. 82, t. 9. (Copied from Shaw, Gen. Zool. 270 , t. 136).

Raja batis, Bloch, Schneid. t. 79. (Copied in Encycl. ii. f. 6).

Raja oxyrhynchus, Mont. Wern. Mem. ii. 423, Jenyns, Brit. An. 501, 20 (not Gmelin).

Raja fullonica, Nils. Syn. Ichth. 119, n. 3 (not Ascanius).

Sharp-nosed Ray, Yarr. Brit. Fish. 2 ed. ii. 424.

Raja lintea, Fries, 29. Ichth. Scand. Miill. t. Henle, Plag. 147 Yarr. Brit. Fish. 2 ed. ii. 556, 1841.

HAB.-North Sea and Scandinavian Seas.

a. Young. Stuffed. Plymouth. Presented by Lieutenant H. F. Spence, R.N.

\section{RAJA OXYRHYXCHUS.}

Fuller Ray, Penn. Brit. Zool. 86, n. 33.

Raja fullonica, Shaw, Gen. Zool. 275. Fabr. Isl.34.

Raja oxyrhynchus, Limn. Gmel. 1506. Lacép. i. 72, t. 4, f. 1. Bloch, Schneid. 80. (Copied in Encycl. pl. 2, f. 7). Müll. \&. IIenle, Plag. 148. Parn. Ichth. Firth of Forth, 267, 1838. Yarr. Brit. Fish. 2 ed. ii. 556, 1841.

Raja ocellata, Mitch. Trans. New York, i. 477. Storer, Rep. Fish. Massachu. 191. De Kay, Nat. Hist. of New York, 369, pl. 65, f. 212 (male), pt. 1. Zool. 1842.

Raia chantenay, Lesueur, Journ. Acad. Nat. Sci. iv. 106, pl.6, 1824.

HAB.-Coast of Europe and East Coast of N. America.

a. Studfed. Firth of Forth, Scotland. From Dr. Parnell's collection.

b. In spirits. Male. 
19. RiJa Kr:ajer.

Raja lienojei, Bïrger, in Miill. \&. Menle, Plag. 149. Rich. Rep. Brit. Assoc. 197, 1845.

HAB.-S.-W. Cuast of Japan.

20. Raja nasuta.

Raga nasuta, Banks, MS.44. Miill. \&. Henle, Play. 150. Har., South Sea.

21. Raja maIroceana.

R.jin maroccana, Bloch, Schneid. 367. Mïll. f. Henle, Plag. 150. HaB.-Atlantic Ocean.

22. RaJa Suтhн.

Raja Smithii, Miill. \&. Henle, Plag. 150.

Hab.-South Africa.

23. Raja capensis.

Raja capensis, Mïll. f. Henle, Plag. 151.

Har.-Cape.

24. RAJA LENPRIER

Raia Lomprieri, Rich. Voy. Erebus f. Terror, 34, pl. 23, 1845. Har.-Port Arthur, Van Diemen's Land.

25. RaJa erinaceus. Hedge-log Ray.

Raia erinacens, Mitch. Amer. Jonm. Sei. ix. 290, pl. 6. De Kay, Nat. Ilist. of New York, 372, pl. 78, f. 246, pt. 1. Zool. 1812. HaB.-New Jerscy.

26. Raja amemicana. Prickly Ray.

Raia americana, De Kay, Nat. Hist. of Now York, 368, pl.66, f. 215 (male), pt. 1. Z̈ool. 1842.

HAB.-Staten Island, Richmond County, North America. 
27. Raja diaphanes. Clear-nosed Ray.

Raia diaphunes, Mitch. Trans. Lit. Phil. Soe. i. 478. De Kay,

Nat. Hist. of Neu+ York, 366, pl. 67, f. 218 (male and female), pt. 1. Zool. 1842 .

Hab.-Coast of New York.

Doubtful Species.

28. RAJA OCELATA.

Raja ocnlata, Risso, Hist. Nat. iii. 149. Miell. \&. Henle, Plag. 151 (not Hitchell).

? Raja bispecularis, Benn. Proc. Zool. Soc. Lond. 146, $1830-31$. H.1B.--Meditemanean.

29. Raja Brasiliensis.

Raja brasiliensis, Miill. \&. Henle, Play. Nacht. 195. HAB.-Brazil.

\section{SYMPTERYGIA.}

The inner borders of the breast-fins approach one another before the head, diminishing obliquely inwards, and from the fore point of the disk, as in Trygon. The hinder edge of the belly-fins is only very slightly undulited, hence the belly-fin is not divided into two lobes. Tail-fin as in Riaja.

Sympterygia, Müll. \$lenle, Mag. Nat. Hist. ii. 90, 1838. Plagiost. 155.

\section{Simpterygia Bonapartir.}

Sympterygia Bonatpartii, Müll. y. Henle, Plag. 155.

H.1в.

\section{URAPTERA.}

Snout and belly-fins of Raja. Tail thiu, and without a terminalfin.

Uraptera, Hiill. do Henle, Hag. Nat. Hist. ii. 90, 1838. Playiost. 155. 


\section{Uraptera Agassizil.}

Uraptera Agassizii, .Mïll. \&. IIenle, Plag. 155.

HAb,-Brazil.

5. The fore points of the breast-lins unite together before the liearl, and form the fore point of the disk. The upper evelid is andnate. The two inner nasal-flaps are protuberant, and have a common, free, shortly fringed under border, which is fastened in the middle only by a sleuder bridle to the upper-jaw. The inner eorners of the nostril are closely approximated to each other under the nasal-flap. Outer nasal-flap wanting. The skull is higher than in the Rays. The spout-holes are large, and elose behind the eyes. Teeth transversely elliptical, with a eross roll, which is blunt or sharp, or divided into points. Belly-fins simple. The tail is thin, often much pointed and whip-like, withont lateral cuticular keels: it is naked, or bears one or more long spines with harbs; it has no fin, whether it be a high or low, ledge-like fin. Skin smooth, or set with tuhercles or prickles. Such spines as precede the lureast-fins of the male Rays, are not extant here.-Trigonisa.

Trigon, Cuv. Règ. An. 2 ed, ii. 399.

Trigones, Mäll. \& Henle, Mag. Nat. Ifist. ii. 91, 1838. Plaginst. 156.

'Trigoninæ, p., Suains. Cab. Cyel. ii. 319.

\section{A. The tail without a spine.-Uroggmni.}

Trygons (\$ 2), Mïll. 9. Henle.

Anacanthi, Miill. \&. Henle, May. Nat. Hist. ii. 90, 1838. Plagiost. 156.

Anacintluis, "Elerenb." Cut. Reg. An. 2 ed. ii. 400.

Anaeanthus, Secains. C'ab. Cycl. ii. 319.

\section{UROGYMNUS.}

Teeth flat. Tail without a rayed fin, with a hem-like, naked, cuticular under-fin, or entirely naked.

Anacanthus, Ehrenb. Mïll. \&. Menle, Plag. 156. Suains. C'ab.

('ycl. ii. 314. (not Groy).

Anacanthus and Urogymuus, Miill. f. Henle, May. Nat. Hist. ii. 90,1838 . 
* Tail withont any fin.

Anacanthus, Miell. f. Henle, Mag. Nat. Hist. ii. 90, 1838.

\section{UrogyanUs AFricanUS.}

Auacanthus africanus, Mïll. \&. Henle, Plug. 157. Raja africanus, Bloch, Schneid. 367.

HaB.-Indian Ocean.

a. Stuffer. India. Presented by T. E. J. Boileau, Esq.

b. Stufied. (Old collectiom).

$c$. Stuffed. Presented by the Zoological Society.

** Tuil with a low, hem-like fin.

Urogymnus, Mäll. f. Henle, Mag. Nat. Hist. ii. 90, 1838.

2. Urogrminus asperrimus.

Anacauthus asperrimus, Miill. \& Henle, Plag. 157.

Raja asperrima, Bloch, Schneid. 367.

Urogymms, Müll. \&. Henle, Mag. Nat. Hist. N. S. ii. n. 13, 14.

HaB.-Indian Ocean.

B. The tail with one or more spines and no fin, or merely a rertical, cuticular hem without rays.-Pastinacæ.

Trygon (true), Miill. \&. Ilenle, Mag. Nat. Hist. ii. 90, 1838.

Pastinaceæ, Miill. \& Henle, Play. 158.

Trygon, Adamson. Cur. Rèy. An. 22 ed. ii. 399.

Trigoninæ, ]., Suains. C'ab. C'ycl. ii. 319.

Pastinacas, "of the Ancients."

\section{TRYGON.}

The disk is oval or rhombuidal. The tail is of the same length or longer than the body, withont a hem, or with hems which do not reach to the other point. The month is slightly arched. The teeth have a point or a cross-roll in the middle, which is sometimes uneven, and before and behind the same there are more or less evident transverse furrows, which become more conspicuous on the side of the tooth. The whole upper surface is more or less wrinkled 
the relum of the upper-jaw has a straight, deeply fringed border, behind it a seeond deeply excavated velum. In the under-jaw generally behind the teeth, a papilla.

Trygon, Adamson. Cur. Règ. An. 2 ed. ii. 399. Müll. \&. Henle, May. Nat. Irist. ij. 90, 1838. Plagiost. 158. Swains. Cab. Cycl. ii. 314.

Trigonobatus, Blainv. Bull. Soc. Phil. 121, 1816.

Dasybatus, Rafin. Caratt. 1810.

* Tail wholly finless.

Himantura, Wiill. f. Henle, Mag. Nat. Hist. ii. 90, $183 \mathrm{~s}$.

Trigon (\$ 3), Cuv. Reg. An. 2 ed. ii. 400.

\section{Trugon Uarnak.}

Trygon Uarnak, Miill. f. Henle, Plag. 158.

Raja Omues Scherit, Forsk. Descr. 918, n. 16.6. Linn. Gmel. 1509. Raja Aruak (Trygon omescherit), Riipp. Atlas, 51.

Pastinachus Uarnak, Rüpp. Chondropt. 9, t. 19, f. 2.

Trigon Russellii, Gray f. Hardu. Illnstr. 100.

Trigon, Hardu. Icon. ined. 88, 91.

Raja Uarnak, Forsk. Descr.

Trygon Russelli, Gray \&. Hardw. Illustr. Ind. Zool. t. 100.

HA B.- Indian and Red Seas.

a. Stuffed. Red Sea. From Dr. Rüppell's collection.

$b, c$. Stuffed. (V ar.) Madras. Presented by T. C. Jerdon, Esq.

\section{Trugon Gerkatid.}

Body rlomboidal, snout projecting, attennated. Pectoral-lins rounded, subangular, the transverse diameter, rather greater than the distance between the tip of the snont, and the cud of the aual rays; upper surface quite smooth, with the exception of three very small, and one larger, oblong, osseous, tubercles, in the centre of the dorsal line. 'T'ail smooth, round, tapering to the end in a very fine point, about four times the length of the body, with a finely serrated spine, which is situated about three inches from its insertion. The general colour in the stulled specinen, is a nniform pale brown with about sixty-five distinet white rings upon the tail. 
Length from tip of snont to extremity of eaudal

Length from tip of snont to base of caudal

in.

Length from tip of snout to anterior edge of orbit 2

Length from tip of snout to large osseous tubercle 4

Breadth aeross the fins $8 \frac{1}{4}$

$\mathrm{H}_{A B}$, -Indian Ocean.

$a, b$. Stuffed. India. From Mr. Argent's collection.

3. Trygon Walga.

Trygon Walga, Miell. 1. Henle, Plag. 159. Hardu. Icon. ined. 83, 84.

HAb,-India, Red sea.

a. Stuffed.

$b$, c. In spirits. Singapore. From Mr. Argent's collection.

4. Trygon plrpurea.

Trygon purpurea, A. Simith, Wïll. f. Henle, Plag. 160.

Hab.-Cape Seas, Mus. Dr. A. Smith.

\section{Doubtful Specics.}

5. Trygox Jabfiara.

Trygon Jabehara, Miull. f- Henle, Play. 160.

Jabehara, Ruyseh, Theatr. i. 27.

Jabebirete, Ruysch, Theatr. i. 27. Maregr. 175. (Copied in Ruysch, Thes. 28, f. 7 ).

Raja guttata, Bloch, Schneid. 361. (Jabcbircte).

HAB.-Brizil.

6. Trugon Aiereba.

Trygon Aiereba, Miill. f. Henle, Plag. 160, 196.

Aiereha, L. Prine. Marcyr. 175. (Copied from Ruysch, Thea. t. 28, f. 6.

Raja orbiculiuris, Bloch, Schneid. 361.

Anacanthes, sp.? Cur. Rì. An. 2 ed. ii. 400.

H $₫$ B. - Brazil. 
* * Tail with a hem-like fin on the underside.

Hemitrygon, Miill. f. Henle, Mag. Nat. Hist. 90, 1838.

7. Trygox Bexnetti.

Trygon Bennetti, Mïll. \& Henle, Plag. 160. Rich. Rep. Brit. Assoc. 197, 1815.

$\mathrm{H}_{\text {a B.-China. }}$.

a. In spirits. China. Presented by J. R. Reeves, Esq.

\section{Trygon thalassia.}

Trygon thalassia, Mrill. \&. Henle, Plag. 161, 197.

Trygon thalassia auch Squatinoraja and Pastinaca marina Dioscoridis, Fabius Columna, Phytobas. 105, t. 28. Gesner, 89 (tail). Aldrov. 428. (Copied from Gesner). Aldrov. 427 (tail with teeth and mouth).

Pastinaca marina, Willoughby, D. 5, f. 3. (Copied from Columna). Trygon Gesneri, Cuv. Rèy. An. 2 ed. ii. 400. (From Gesner, 77).

HAB.-Adriatic.

a. Stuffed.

b. (Tail).

*** Tail with a cuticular hem on the upper and under side.

Trygon (restricted), Miill. \&. Henle, MIag. Nat. Hist. ii. 90, 1838, 'Trygon (\$ 1), Cut. Règ. An. 2 ed. ii. 399.

\section{Trygon pastinaca.}

Trygon pastinaca, Bonap. (in Mïll. \&. Henle, Plag. 161).

Pastinaca mariua, Belon. 94. (Copied from Gesuer, 799). Aldrov. 426. Moscarlo, 224.

Pastinuea, Salviani, 144, t. 49. (Copied from Willoughby, C. 3). Jonst. ix. 7. Bonnan. Mus. Kirck. 161, t. 39, f. 24.

Raja pastinaca, Mïll. Prodr. 310. Bloch, Schncid. 82. (Copied from Encycl. iii. f.8). Linn. Faun. Suec. El. Retz. 304. Linn. Gmel. 1509, 7. Cornide, Ens, 126. Bloch, Schneid. 360. Shaw, Gen. Zool. 182. Risso, Ichth. 10. Nils. Prodr. 120. Jenyns, Brit. An.518. Blaine. Faun. Fr. 35, pl. 6.

Pastenade, Duham. § 9, 1]. 9, f. 8. 
Trygon lymma, Geoff. St. Hilaive, Descr. Eg. 333, pl. 27, f. 1.

Trygon vulgaris, Risso, Hist. Nat. iii. 160.

Trygou Aldrovandi, Risso, Hist. Nat. iii. 160.

Dayatis Pastinaca, Raf. Ind. 49.

Pastenaque commune, Dict. Des. Sc. Nat. 25.

Sting-Ray, Yarr. Brit. Fish. 2 ed. ii. 442.

Trygon Pastinaca, Pam. Trans. Edinb. Roy. Soc. 145, 1839. Bonap. fase. vi. Miill. \&. Henle, Plag. 161.

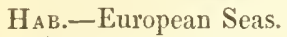

a. Stuffed. From Dr. A. Smith's collection.

b. Stuffed. Plymouth. Presented by Lieut. F. H. Spence.

10. Trigon Brucco.

Trygon Brucco, Bonap. in Müll. đ. Ilenle, Plag. 162.

$\mathrm{H}_{\mathrm{AB}}$.- - South America.

a. In spirits. South America. Presented by Sir R. Schomburgk.

\section{Trygon violacea.}

Trygon violacea, Bonap. Faun. Ital. fasc. i. Müll. \&. Henle, Plag. 162.

Нав.-Sicily.

\section{Tryggx Sabina.}

Trygon Sabina, Lesueur, Phil. Acal. ir. 109. Miill. I. Henle, Plag. 163. De Kay, Nat. Hist. of New York, 375, pt. i. Zool. 1842.

Raie tuberculée, Lacép. ii. 106. Cur. Règ. An. 2 ed. ii. 399. Trygon gymnura (young), MIill. Erman. Reis.

Trygon osteosticta (old, with the tail broken), Müll. Erman. Reis. $\mathrm{H}_{\text {AB. }}$ - South America.

a. In spirits? South America. Presented by Sir R. Schomburgk.

$b$. In spirits.

\section{Trigoy inbricata.}

Trygon imbricata, Mull. \&. Henle, Plag. 164.

Raja imbricata, Bloch, Schneid. 366.

Isakurrah tenkee, Russ. 1, t. 4. Cuv. Reg. An. 2 ed. ii. 399.

HAB.-Coromandel, Java. 
14. Trygos Kinnin.

Trygon Kuhlii, Mull. \&. Henle, Plag. 164.

H.в,-India.

15. Trygon Aliajei.

Pastinaca Akajei, Burger, MS.

Trygon akajei, Mull. f. Henle, Plag. 165. Rich. Rep. Brit. Assoe. $197,1845$.

H.1B.-South-West of Japan.

16. Trygon Zugei.

Trygon Zugei, Burger, in Mïll. \&. Henle, Plag. 165. Rich. Rep. Brit. Assoc. 197, 1845.

HАв.-Japan, India, China.

17. TrYgon SAYi.

Trygon Sayi, Miill. \&. Henle, Plag. 166.

Rija Say, Lesueur, Phil. Acad. i. 42.

Has.-The American Coast, West Indics.

a. In spirits. Presented by the Zoological Society.

18. Trygon inYstrix.

Trygon hystrix, Müll. \&. Ihenle, Plag. 167, 197. D'Orb. I'oy. Atlus, Ichith. pl. 17.

Trygon hystrix? Sehomb. Nat. Lib, v. 181, pl. 20, 1843.

$\mathrm{H}_{\mathrm{A} \text { B. }- \text { South America. }}$

19. Trygor strogylopterus. Round-winged Trygon. Trygon strogylopterus, Schomb. Nat. Lib. v. 183, pl. 22, 1843. Haв.-Rio Branco.

20. Trygon garrapa. Ocellated Trygon.

Trygon garrapa, Schomb. N'at. Lib. Ichth. v. 182, pl. 21, 1843. Hab.-Guiana, Rio Branco. 
21. Trggon hastata. Whip Sting Ray.

Pastinaca hastata, De Kay, Nat. Hist. of New York, 373, pl. 65,

f. 214 (female), pt. 1. Z Z ool. 1842.

? Raja centromra, Mitch. Trans. Lit. Phil. Soc. i. 479.

HaB.-Long Island, North America.

22. Trygon carsed.

Trygon carnea, Rich. Rep. Brit. Assoc. 197, 1845.

Hab.-Clina Seas, Macao.

\section{Doubiful Tryyones.}

1. Raja lavis, Gromov. Mus. i. 64, 141. Zooph. 37, 158.

2. Raji, No. 1, Broune, Jam. 459.

3. Raja, No. 2, Browne, Jam. 459.

4. Raja, No. 3, Browne, Jam. 459.

5. Raja cucultrs, Lacép. Poiss. iv. 669, 678.

6. Darybatis Ijo, Rafin. Caralt. 16. Iroxis rigo, Index.

7. Tenkee Shindraki, Russ. Ind. Fish, 5. C'ur. Rìy. An. 2 eıl. ii. 399.

\section{श. ELIPESTRUS.}

Tail short or deficient, the hase covered with strong spiny excrescences. Budy oval. Eyes prominent. Nostrils very large.

1. Eltpescrus spinicauda. Spine-tailed Elipesums.

Elipesurus, Schomb. Nat. Lib. v. 184, 1843.

Elipesurus spinicauda, Schomb. Nat. Lib. v. 184, pl. 23, 1843.

Naree-naree, local nome.

Hab.-Rio Branca, Fort San Joaquim.

\section{DASYATIS.}

The disk is nearly, or more than twice as broad as long, and the tail is short, for the most part shorter than the body. Tail naked or with low tins. Mouth a little arched. The dental-plate reaches 
to the corner's of the mouth. Teeth with from $1-3$ points. The npper velum is indistinct without a fringe. The papillæ are wanting in the under-jaw. The skin is smooth or studded with knobs.

Pteroplatea, Miill. \&. Itenle, May. Nat. Hist. 90, 1838. Plagiost. 168

Dasyatis, Rafin. Index, 49. Anal.93. Char. I6.

Trygon (\$3), Cur. Règ. An. 2 ell. ii. 400.

1. Dasgatis altavel.

Pastinaca marina altera, pteryplatea, altavela, Columna, Aquat. 2. Pastinaca marina alteri, Alitrou. 43s. Willoughby, 65. (Copied from Columna). Ray, 24, 3.

Raja altavela, Linn. Gmel. 1509.

Dasyatis altavilla, Rafin. Ind. 4 9.

Trygon altavela, Bonap. xiii. Lone, Proc. Zool. Soc. Lond. 92, 1839.

Pteroplatea altavela, Müll. f. IIenle, Plag. 168.

Pastinaque de F. Colmmna, Blainr. Fauna Fr. 37

$\mathrm{H}_{\mathrm{AB}}$.-Mediterranean Ocean.

2. Dasyatis Canariensis.

Pteroplatea canariensis, Valeuc. Webb, Canar. t. Weigmann, Arch. ii. $201,1845$.

H.s.-Canaries, Ilebb.

3. DAsTatis MICRURA.

Trrgon micrura, Bloch. Schneid. 300. Cur, Rèq. An. 2 ed. ii. 400. Raja pocilura, Shaw, 291. IIardw. Icm. ined. 79, 81.

Teukee Kunsul, Russ. 6.

Tryen poecilurus, Benn. Life of Raffles, 69.4.

Pieroplatea micrura, Mïll. \$. Henle, Plag. 169. Rich. Rep. Brit. Assoc. 197, 1845 .

HaB,-Indian Ocean.

a. Stuffed. Calcutta. From Mr. Bartlett's colleetion.

b. Stuffed. India. Presented by T. E. J. Boilenu. Esq̨.

c. In spirits. Singapore.

Var.? Japonicus.

a, b. In spirits. Japan.

c. In spirits. China. Presented by J. R. Reeves, Esq. "Pteroplatea Japonicus, Gray, MSSS. Brit. Mus." 
4. DASYATIS M.ACLURA.

Trygon machura, Lesuew, Phil. Joum. i. 41. Cuv. Règ. An. 2 ed. ii. 400 .

Pastinaca maclura, De Kay, Nat. Hist. of New York, 375, pl. 65,

f. 213 (female), pt. 1. Zool. 1842.

Pteroplatea maclura, Miill. \&. Ilenle, Plag. 169.

His.--North America.

\section{HYPOLOPHUS.}

Body formed as in Trygon. The tail with a high inferior fin, which as in Trygon does not reach the end of the tail. The upperfin wanting. It differs from Trygon principally in the peculiar form of the mouth and the teeth. The under-jaiv projects forward in the middle, and on each side of the point there is a dish-shaped concavity. The edge of the upper-jaw is much deeper in the middle; at the point of the under-jaw it bulges, and on the side is very convex. The teeth are pared, hexagonal, broader than long: in the upper-jaw in the middle small, at the side large; in the nuder. jaw seemingly equally large, but towards the outermost smaller.

Hypolophus, Miill. \&. Henle, Mag. Nat. Hist. 90, 1838. Plagiost. 170.

Tyygon (§ 2), Cur, Rèy. An. 2 ed. ii. 399.

\section{Hypolophus Sephen. Pearled Ray.}

Raja Sephen, Forsh. Descr. 17. Lacép. i. 123. Bloch, Schneid. 364.

Pearled Ray, Shaw, Gen. Zool. 288.

Trygon Sephen, Cur. Règ. An. 2 er. ii. 399. Rüpp. Allus. 52.

Rüpp. Wirb. 19, f. 5 (tceth). Hurdw. Icon. ined.92.

Trygon Forskalii, Rüpp. Atlas, 53, 13, 2

Hypolophus Sephen, Miill. y. Henle, Play. 170.

Var. ? IVolga tenkee, Russ, 3.

Hab.-Indian Ocean.

a. Stuffed.

b. Stuffed.

c. Stuffed. India. Presented by J. C. Jerdon, Esq., M.D.

d, e. Stuffed. India. From Mr. Warwick's collection. 


\section{TENIURA.}

Disk roundish. Tail not much longer than the body, depressed before the spine, compressed behind the same, with a ligh underfin, which begins behind the spine and reaches quite to the end. On the upper side of the tail there is often a shorter or longer, low euticular hem up to the point of the tail. The spine shortly before the middle of the tail. Nostrils approximated to each other as in 'Trygon. Teeth flat, with a cross-roll or pointed. Mouth straight or undulated. The upper velum wholly straight, the muler one without a papilla.

Treniura, Miill. \&. Henle, May. Nat. Hist. ii. 90, 1838. Plagiost. 171.

Trygon (\$ 2), Cuv. Règ. An. 2 ed. ii. 400.

Pastinaca, Suains. Cab. Cycl. ii. 319.

\section{TENIURA LYMMA.}

T'æniura Lymma, Mïll. \&. Henle, Plag. 171.

? Raja lymma, Forsk. Deser. 17.* Lacép. i. t. 4, f. 2, 3.** Shaw, Gen. Zool. 287. Linn. Gmel. 1511. Bloch, Schneid. 361. Cur. Règ. Au. 2 ed. ii. 400.

Raie torpille, Lacép. i. t. 6, f. 1 (without spines).

Trygon lymma, Cur. Reg. An. 2 ed. ii. 400. Riipp. Allas, 51, t. 13,

f. 1. Ruipp. Wirb. 19, f. 4 (teeth).

Trygun ornata, Gray \&. Hardw. Illustr.

Trygon Halgani, Lesson, Duperry, Voy. pl. 2, p. 100.

a. Stuffed. Red Sea. From Dr. Ruppell's collection.

b. In spirits.

c. In spirits. Singapore. From Mr. Argent's collection.

d. In spirits. Singapore. Presented by Gen. Hardwicke.

e. In spirits. (Very young).

\section{Texiura MeYexi.}

Treniura Meyeni, Müll. 5. Henle, Plag. 172.

a. In spirits. Cape Upstart. Presented by J. B. Jukes, Esq. 


\section{T.exicra Grabita.}

Tseniura Grabata, Müll. \$. Henle, Plag. 182.

Trygon Grabatus, Isid. Gentfr. St. Hil. Eg. 332, pl. 25, f. 1. "..

Raia Lymma, var. Cur. Rey. An. 2 ed. ii. 400.

Hsв.-Alexandria.

\section{T.FNIER มOTORO.}

Tæniura motoro. Wiill. y. Henle, Play. Nachtr. 197. Ratja motoro, Natterer.

Has.-

C. A spine upon the tail und terminal-fin with rays.-Urolophi. Urulophi, Mïll. 1. Henle, Maty. Nut. Hist. ii. 90, 18i3s. Playiost. 173.

Leiobatus aut R. lævis, Blaim. Bull. Soc. Phil. 121, 1slti.

\section{TRYGONOBATUS.}

Disk round or rhomboidal. Tail without a back-fiu, with a terminal-fin which is wider below, but reaches forwards above, with cartilaginous rays. Tail fint forwards, compressed behind. Teeth and mouth as in Trygon. Above, a gently undulated relum: the under velum with five warts.

Trygonobitus, Dum. Dec. Ichth. 6.

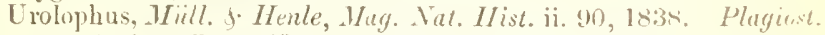
173. (not Dumeril).

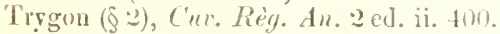

Leiobatus (erucistus), Blaine. Bull. Soc. Phil. 1:21, Ist6.

\section{Trugoxobates torpenixis.}

Pastinaca marina, Sloune, fom. Bd. ii. 27t, t. 2:46, f. 1

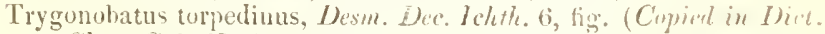
Cluss. Sici. Nat.).

Raja jamaicensis, C'uv. Rig. An. 2 ed. it. 100. (Coppied from Sluane). Bune. Zool. Journ. s. s.. (taii).

Urolophus Indianus, Wiell. Henle, Ms. Cat. of Zool. Soc. Lomel. ก. 796.

Urolophus torpedinus, Hïll. \&. Henle, Play. 173.

a. In spirits. Cuba. 
2. Trigonobitus aurantiaus.

Urolophus aurautiacus, Miill. \&. IIenle, Plag. 173.

? Raja eruciatil, Laeép. Ann. dn Mus. iv. 201, pl. 55, f. 2. Pastinaca J einorui, Bürger, MS.

Trygon (\$ 2) eruciata, Cuv. Règ. An. 2 ed. ii. 400.

Leiobatus cruciatus, Blainr. Bull. Soc. Phil. 121, 1816.

HAB.-Grot to Island.

3. Trygonomatus amatus.

Urolophus armatus, Valene. in Miill. \&. Henle, Plag. 174. HaB.-Antilles.

4. T'rygonobatus ephippiates.

Urolophus ephippiatus, Rich. Voy. Erebus \& Terror, 35, pl. 24, 1845.

Haв.-Storm Bay, Van Diemen's Land.

D. A spine upon the tail, and a rayed back-fin before the spine. -Trygonopteræ.

Trygonopteræ, Miill. of Ilenle, Plag. 171.

\section{TRYGONOPTERA.}

Disk-shaped, as in Trygon. Teeth somewhat pointed. Tail short, broader at the end, with a small back-fin immediately before the spine.

Trygonoptera, Müll. \&. Menle, Plag. 174.

\section{Trygonoptera testacea.}

Trygonoptera testacea, Mïll. \&. Henle, Plag. 174. Riajat testacea, Banks, $M S .46$.

HaB.-New Holland. 


\section{ETOPLATEA.}

Like Pteroplatea, with a back-fin before the spine. Etoplatea, Valenc. in Müll. f. Henle, Plag. 175.

\section{Etoplatea tentaculata.}

Etoplatea tentaculata, Miill. \& Menle, Plag. 175. H. $\mathbf{B}$-India, Red Sea.

6. The roots of the breast-fins loose; their rays wholly on the side of the head, but the rays are again developed before the head, and form a kind of head-fin which constitutes the point of the disk. The head thereby projects from the disk up to the region of the gills; and it is mure boldly arched than in the other families. The nasalflaps of both sides are tied to a four-sided lobe, which is fringed on its under border, and reaclies to the mouth. The nostrils stand close together in the middle, and are separated only by a thin fillet which passes over the dorsal surface of the nasal-flap from both angles of the mouth, and is gently pointed in the middle. Mouth transverse. The dental surface of the jaws extends far into the carity of the mouth. 'Teeth large, mosaic-like, even pavement-like. The upper velum springs from the gums and cheeks, is very long, with a convex border, and is fringed in the middle. The under velum lies elose to the dental border. Only one papilla behind the same. Eyes and spout-holes in the lateral edges of the skull. spout-holes separated from the eyes by a broad bridge. Eyelids wanting. Tail long, whip-formed, with a back-fin on its root and a spine behind the same.-MYLiobativa.

Myliobatis, Mïll. \&. Henle, Mag. Nat. Hist. ii. 90, 1838.

Myliobatides, Miill. o. Henle, Plag. 176.

Leiobatus, Rafin. Curatt. 1810.

Etobatus ant R. aquilæ, Blaine. Bull. Soc. Phil. 121, 1816.

Pterocephalinæe, Su'ains. Cub. C'ycl. ii. 319.

\section{MYLIOBATIS.}

Snout pointed through the united foremost rays of the breast-fin. The edge of the conjoined nasal-flaps is straight. Mouth transrerse. Both jaws with a straight border. 'Teeth six-cornered, 
bebind one another, and forming in the middle a row, conformable with the border. transverse crowns. On the sides smaller four-cornered, parement-like pieces, which catch in the spaces of the middle crowns. The dental surface of the upper-jaw is conrcx from before, backwards and from sicle to side; that of the under-jaw tlat, scarcely concave, neither occupy the whole breadth of the jaw.

Irliohatis, Dum. Zonl. Anal. 1806. Cur. Règ. An. 2 ed. ii. 400.

Müll. S. Henle, Mag. Nat. Hist. ii. 90, 18:38. Plagiost. 176.

Suains. Cab. C'ycl. ii. 319.

Etobatus ant R. aquilæ, Blainr. Bull. Soc. Phil. 121, 1 s16.

Leiobatus, Rafin. C'aratt. 93. 1810.

Spines sometimes numerous, see Freycinet, Zool. t. 42, f. 3, with fire spines.

\section{Mrliobatis aerila.}

Mrliobatis aquila, Risso, Hist. Vat. iii. 162. Agassiz, iii. t. D, f. 9. (teetli). Cur, Reg. An. 2 ed. ii. 100. Miill. \& Henle, Plag. 1;0.

Aquila marina, Bélon. 97. (Copied in Gesner, s7).

Aquila, Salr. 147. f. 50. (Copied in Willoughby, 2). Jonst. ix.

9. Ruysch. Thes. ix. 9. Aldror. 439, 440. Brunnich, 3, n.

4. Duhamel, sect. ix. pl. 10.

Aquilone, Columna, de Aquat. 2.

Paja aquila, Linn. Gmel. 1508, n. 6. Encycl. f. 10. Bloch, Schneid. 360. Risso, Ichth.9. Blainr. Faun. Fr. 38, t. \%. Eagle Rar, shau, Gen. Zool. 1+1. (Copied from Willoughby). Yarr. ii. 145.

Yrliobatis borina, Genff. Egypte, 336, pl. 26, f. 1 .

Mrliobate aigle, Dict. Sci. Wat. 24.

Mriliobatis aquila. Risso, Hist. Nat. iii. 162. Agassiz, iii. t. D, f. 9, (ceeth). Cur. Reg. An. 2 ed. ii. 100.

Whip Rur. Jenyns, Brit. An. 519.

Mrlichatis noctula, Bonap. fasc. 2.

Pastinaca marina, . Matthiol. 325.

HaB.-Medierranean, Cape.

a. stuffed.

b. Stuffed.

c. In spirits. (Bleached).

d. In spirits. Yuung. Madeira.

e. In spirits. Head. Madeira. 


\section{Mriobatis Niedhofit.}

Aquila marinæ species, Willoughby, 6, t. 10, f. 3. (App.)

Raja Nieuhofii, Bloch, Schneid. 3ut. Cuv. Règ. An. 2 ed. ii. 400.

Mookarrha Tenkee, Russ. t. 7.

Fasciated Ray, Shau, Gen. Zool. 286. (Copied from Milloughby).

Myliobatis aquila, Bonap. fasc. '2. Hardw. Icon. ined. 97.

Raja macrocephala, Banks, MS. 48.

Myliobatis Nieuhofii, Miill. f. Henle, Plag. 1\%厅. Rich. Rep. Brit. Assoc. 198, 1845 .

HAв.-India, New Holland, Mediterranean.

3. Myliobatis Miluev.

Myliobatis Milrus, Valenc. in Miill. f. Henle, Plag. 178.

HaB.-Red Sea.

\section{MrLiobatis MaCUlates.}

Myliobatis maculatus, Gray f. Hardu. Illustr. 101. Hardu. Icon. ined. Miill. f. Henle, Plag. 17s. Rich. Rep. Brit. Assoc. 198,1845 .

H.s.-India.

a. Stuffed.

\section{Mrlobatis rulter.}

Iyliobatis vultur, Miill. I. Henle, Plag. 179. Rich. Rep. Brit. Assoc. 19s, 1845.

HaB.-China.

a. In spirits. China. Presented by J. R. Reeres, Esq.

6. Mrimobatis oculets.

? Myliobatis oeuleus, Rich. Rep. Brit. Assoc. 198, 1845.

$\mathrm{H}_{\mathrm{A}} \mathrm{B}$-China.

7. MYliobatis episcopts.

Myliobatis episcopus, Valenc. Webb, Canar. t. f.

HAB.-Canaries. 


\section{2. ЕTOBATIS.}

The snout pointed, undivided. The under edge of the conjoined nasal-flaps deeply notched. The bridle of the nasal-flap is beset with papilla, which range themselves transversely before the upperjaw. The upper-jaw has a straight edge. The crowns of the teeth form a row on each jaw, and in the under-jaw they are arehed parallel to the edge of the last ones. The crowns of the teeth do not occupy the entire breadth of the jaw.

Myliobatis (( 2), Cur. Règ. An. 2 ed. ii. 401.

Etobatis, p. Blaine. Bull. S'oc. Phil. 121, 1816.

Etobatis, Miill. \& Henle, May. Nat. II ist. ii. 91, 1838. Plaginst.

179. Suains. Cab. Cycl. ii. 319.

\section{Etobatts Narinari.}

Etobatis Narinari, Miill. \&. Henle, Plag. 179.

Narinari, Lib. Princ. Braz. Naturg. i. t. 332. Marcgr. 176. (Copied from Ruysch, Thes. t. 39, f. 6).

La raie aigle, Lacép. i. t. 6, f. 2.

Raja Nariuari, Bloch, Schneid. 361. Euph. in Vetcnsh. Acad. Handl. 217, t. 10, I790.

Eel-Tenkee, Russell, 8 .

Guttated Ray, Shaw, Nat. Mise. 142.

Raja quinqueaculeata, Quoy \&. Gaim. Freyc. 200, pl. 43, f. 3.

M yliobatis Narimari, Bemu. Life of Ratfles, 694. Agassiz, iii. t. D,

1, 2. (teeth). Willonghby, t. C, 1, f. 5. (Copied ron Marcgr.). Myliobates Eel-Tenkee, Rüpp. Chondropt. 11, t. 19, f. 3. (teeth).

H.B.-Indian Ocean.

a. Stuffed.

b. In spirits. Sumatra. From Sir Stamford Raffles' eollection.

c. In spirits. Presented by the Zoological Society.

$d, e$, Stuffed.

\section{ETOBatis FlaGeliul.}

Raja flagellum, Bloch, Schneid. 361, t. 73. Etobatis flagellum, Mrill. \&.Henle, May. 180. Rich. Rep. Brit. Assoc. 19s, 1845. Icon. Recres, 273. IIard. Cart. 101. II A s,-ludia, Red Sea, China. 


\section{RHINOPTERA.}

Snout deeply divided by a mesial notch. The cranial-fin does not lie in the same plane with the breast-fin, but more beneath, and it is joined to the uuder root of the breast-fin. Noreover, the rars of the cranial-fin begin wider behind than the rays of the hreast-fin end. The under edge of the nasal-1lap straight; its outer angle pointed. On each side of their dorsal surface is a longitudinal fold. The borders of both jaws straight. The teeth stand in from three to five rows of broad six-eornered crowns, near to one another, and diminishing in size towards the sides. Moreover, on the outside is a smaller row, which is not broader than long: they occups the whule breadth of the jaw.

Miliobatis, s]., Greoff. Desc. Egypt.

Rhinoptera, Kuhl, MS. ('uv. Réy. Au. 2 ed. ii, 401. Miill. 1. Henle, Mag. Nat. Hist. ii. 91, 183๙. Plagiost. 1s1. Snains. Cab. Cycl. ii. 319.

\section{Rhinoptera naliginata.}

Rhinoptera marginata, Cur. Réy. Au. 2 ed. ii. 401. Mill. Itenle, Pleg. 181.

Iyliobates marginata, Is. Geoff. St. IIil. Descr. d'Eg. 334, ㄱ. 25, f. 3,4 .

Has.-Mediterranean.

a. Teeth.

2. Rhivopteina LaLivdit.

Rhinoptera Lalandii, Valene. in Miell. y. Henle, Play. 1 s..

H.B.-Brazil.

3. RHIXoptera pRasiLleNSIS.

Raja Mṛliobatis, Jussieu.

Rhinoptera brasiliensis, Cur. Rey. An. 2 eà. ii. 401. Müll. Myxi. 237. Miill. f. Heule, Plà. 18.. Jussien, Mém. de Par. 1721. pl. 4, f. 12.

Myliobatis Jussieu, 1yussiz, iii. t. D, 8. (teeth). (Copied from Jussien). Oxen, Udont. pl. 25, f. 2.

Hab.-Brazil. 
4. Rhixoptera javanica.

Rhinoptera javanica, Miill. \&. Hcule, Plag. 182. Monro, Schncid.

Phys. d. Fische. t. 34, f. 2-4. (teeth).

HAB.-Java.

5. RHINOPTERA ADSPERSA.

Rhinoptera adspersa, Valenc. in Mïll. \&. Henle, Plag. 183.

HАB.-India.

\section{Rhinoptera quadriloba. Cow-nose Ray.}

Rhinoptera quadriloba, Cur. Règ. An. 2 ed ii. 401. De Käy, Nat. Hist. of New York, 375, pl. 66, f. 217, pt. 1. Zool. 1842.

Raia bonasus, Mitch. Trans. Lit. Phil. Soc. i. 479.

Raia quadriloba, Lesueur, Journ. Acad. Nat. Sci. i. 44. Miell. \$. IIenle, Plag. 183.

HAB.-N. America.

7. Rhinoptera Suithit.

a. Stuffed. Antarctic Seas. From the Antarctic Expedition. Presented by the Admiralty.

\section{Doubtful Species.}

1. Myliobatis Tremenvillii, Lesuenr, Jomrn. Acad. Phil. iv. 112.

2. Myliobatis, Lucép. i. t. 6, f. 3.

7. The fore edge of the head straight, transverse. The cranialfins spring from the under edge of the root of the breast-fins, and stand like ears on the sides of the head. The onter edge of the head-fin is curled upwards and inwards. The mouth before or beneath, very broad, reaches nearly to the ears. The under edge of the conjoined nasal-flaps straight. The nostrils wide, untwards, near the hearl-fins. Teeth very small. The eyes lie on the side of the skull, and the fore edgre of the breast-fins begins behind them. The spout-holes, situated on the dorsal surface of the body, are separated from the eyes by a wide interspace. The tail is as long or longer than the body, and bears a back-fin behind which there is a spine.-Cephaloptera. 
Cephalopteræ, Mïll. \& Henle, Mag. Nat. Hist. ii. 91, 1838. Plagiost. 184.

Ors. - In $C$. Olfersii the tail is short, and there is no spine behind the lack-fin, nor is there any spine in Mïller \& Henle's figure of Cephaloptera.

\section{CEPHALOPTERA.}

Month on the ventral surface. Teeth in hoth jaws small, flat, parement-like, of diverse forms. The rays of the breast-fin extend close up to the skull. The fore edge of the breast-fin describes a convex curve from the skull, behind the eyes, and up to the point.

Cephaloptera, Dum. Zool. Anal. Cnv. Rèq. An.2 ed. ii. Muill. f. Henle, Mag. Nat. Hist. ii, 91, 1838. Plagiost. 184.

Dicerobatis, Blainu. Bull. Soc. Phil. 121, 1816.

Pterocephala, Swains. Cub. Cycl. ii. 319.

Mobula, Rafin.

\section{Cephaloptera Giorna. Cephaloptera.}

Cephaloptera Giorna, Mill. \&. Henle, Plag. 184. Gionn, Mém. Acad. Turin, 2, f. 1.

Raja fabroniana, Lacép. v. 663, t. 20.

Raja Giona, Risso, Ichth. 14, 1. Cuv. Règ. An. 2 ed. ii. 402.

Raja Massena, Risso, Ichth. 15, 2, 1. 293.

Cephalopterus Massena, Risso, IIist. Nat. 164.

Raja Mobula, Blainx. Fann. Fr. 41, pl. 8.

Raia cephaloptera, Bloch, Schneid.

Mobula auriculata, Rafin. 1810.

Apterurus fabroni, Rafin. 1810.

Pterocephala Giorna, Swains. Cab. Cycl. ii. 319.

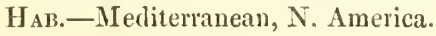

2. Cephaloptera Olfersir. Indian Cephaloptera.

? Eregoodoo-Tenkee, Russell, 9, 10.*

Cephaloptera Olfersii, Mïll. Myxin. 311. Müll. f. Henle, Pluy. 185.

a. Stuffed. Indian Ocean. Presented by T. C. Jerdon, Esq. 
3. Cepraloptera Kunliı. Kunhl's Cephaloptera. Cephaloptera Knhlii, Valenc. in Miill. \&. Henle, Plag. 185. HaB.-India.

4. Cephaloptera Japonica. Japan Cephaloptera. Cephaloptera Japonica, Müll. \& Henle, Plag. 185. HAB.-Japan.

\section{CERATOPTERA.}

Mouth at the end of the snout: the border of the upper-jaw concave: the under-jaw convex forwards. Teeth wanting in the upper-jaw: in the under-jaw they are small scale-like leaflets. The rays of the breast-fins do not go up to the skull, and a considerable part of the root of these fins rests between the head-fin and root-fin, without rays. The fore edge of the fin is incurved, so that in the beginning it lies on a line with the lateral edge of the skull, and seems to spread itself outwards, first at the third gill-opening.

Ceratoptera, Müll. \&. Henle, Mag. Nat. Hist. ii. 91, 1838. Plagiost. 186.

\section{Ceratoptera Johnif. Sea Devil.}

Ceratoptera Jolnii, Mïll. \&. Henle, Plag. 186.

? Cephaloptera Giorna, Lesueur, Phil. Acad. 116. t. 4, pt. 1.

Sea-Devil, Lamont, Edin. Phil. Journ. ix. 113. Banc. Zool. Journ. 444.

Cephalopterus vampyrus, Mitch. Ann. Lyceum Nat. Hist. New York, i. pt. 1, 23, t. 2, f. 1. Isis, 1063, t. 28, f. 4, 1832. De Kay, Nat. Hist. of New York, 377, pl. 67, f. 219, pt. 1. Zool. 1842 .

HAB.-Jamaica.

2. Ceratoptera Ehrenbergil. Elirenbergh Sea Devil.

Ceratoptera Eurenbergii, Miill. \&. Henle, Plag. 187. Ehrenb. Symb. Phys. incd. Rüpp. Chondropt. 11. Mrill. Myxin. 311.

$\mathrm{H}_{\mathrm{A} B}$. - Red Sea. 


\section{Doubtful Cephaloptera.}

1. Diabolus marinus, Nienh. of Willoughby, Ichth. App. t. 1, f. 3.

2. Squalus edentatus, Brumich, 6, n. 14.

3. Devil, Penn. Arct. Zool. Suppl. 104.

4. Mobular, Duhamel ( $($ ix.), 293, t. 17.

5. Diable de Mer, Le Gent. Voy. i. 617, t. 3.

6. Sea-Devil, Petiver, Gaz. i. t. 54, f. 2.

7. Raia Mobular, Schneil. Pompt. Leps. 73, 90. 


\section{Section D. CYCLOSTOMIA.}

Gills saccate; body elongate; pectoral and ventral-fins none.

Cyclostomia, Rafur. Anal. Nat. 94, 1815.

Cyclostomes, Blainr. Bull. Soc. Phil. 1816, 120. Jour. de Phys. $1816,254$.

Cyclostomata, Mïll. Abhandl. Akad. Wissensch. Berlin, 1834, 65.

Mag. Zool. f. Bot. i. 406, 1836.

Sub-class 4. Marsipobranchii, Bonap. Syst. Ichth. 1838, 14.

Cyclostomi, Helminthoidei, Petromyzonidæ, Bonap. Syst. Ichth. $1838,14$.

Petromyzidæ, Gray, Syn. B. M. 1842, 148, 150.

Lampetræ, Ray, Syn. Pisc. 35.

Duméril (Zoologie Aualytique, 8ro. 1806, p. 101) divides the Cyclostomes thus:-

1. Pctromyzon, with seven branchial holes.

2. Gastrobranches, with only two branchial holes.

\section{Fam. 1. PE'TROMYZONIDE.}

Nasal aperture closed, atd the palate entirely corered with skin.

Lampredia, Rafin. Anal. Nat. 94, 1818.

Petronyzouidæ (Petromyzoniui), Bonap. Syst. Ichth. 1838. De Kay, Nat. Ilist. of New York, 379.

(Fam.) Hyperoartia, Miill. Abhandl. Akad. Berlin, 1836, 77. May. Zool.s. Bnt. i. 406.

Petromyzidæ, Gray, Syn. B. 1I. 1842, 148, 150.

Rafinesque names, but does not characterize, the genera Lampreda and Pricus, (Anal. Nat. 94, 1815).

Miuller (Abhandl. Akad. Bcrlin) divided the genera thus:1. Pteromyzon, with visible teeth.

2. Ammocates, without visible teeth. 


\section{Synopsis of Generd.}

a. Petromyzonina.-Teeth distinet; eyes visible.

1. Petrourzon.-Upper inner teeth two, conical, close together ; lower single, crescent-shaped; labial teeth numerous, conical ; lingual teeth two, pinnate, t. $1, \mathrm{f} .1$.

2. Lampetra. - Upper and lower teeth transrerse, crescentshaped; labial teeth in two submarginal rows; inner lateral teeth larger, two or three-lobed, lingual teeth peetinate, t. 1, f. 2.

3. Geotria.-Upper and lower teeth transrerse, crescent-shaped; upper lobed; labial teeth numerous, distant, acute, innermost largest; lingual teeth elongate, conical, arched, t. 1, f. 3.

4. Velasia.-Upper and lower teeth transverse, crescent-shaped upper two-lobed; labial teeth numerous, crowded, truncate; innermost largest; lingual teeth elongate, arched.

5. Ciragola. - Upper internal teeth two, far apart, three-lobed lower crescent-shaped, nine-lobed ; labial teeth transverse, band-like? four tubercles; lingual teeth flattened, t. 1, f. 5 .

6. Mordacia. - Upper inner teeth two; lateral three-lobed; lower nine, conical, in an arched series; labial teeth conical, in a single sub-marginal series; lingual teeth elongate, conical, arched, t. 1, f. 6 .

b. Ammocœtina.-Teeth none; eyes hidden.

7. AnvacETES.

\section{a. Petromyzonina.-Teeth distinet.}

\section{PETROMYZON.}

Upper inner teetl two, triangular, close togetler. Lower inner tooth single, large, crescent-sliaped, many-toothed. Labial teeth conical, acute, numerous, in diverging, arched series; the inner one largest, and gradually becomiug smaller near the edge. Tongue with two compressed, pectinated teeth abore, and a broad, lunate. dentated tooth beneath, which is strongly bent up between the upper teeth in the centre, t. $1, f .1$.

Yarr. Brit. Fish. fig. p. 603 (not good). De Kay, Zool. Nex York. t. 56,216 . (bad). 
Petromyzon, sp., Limn. Syst. Nat.; Rafin. Anal. Nat.; Müll. Abandl. Alad. Berlin, 1834, 77. (1836).

I'ctromyzon, Gray, Lroc. Zool. Soc. 1851.

\section{Prtronizon marinus. The Lampley.}

Petromyzon marinus, Linn. Bloch, iii. pl. 77. Limn. édit. de Ginclin, Faun. Suec. 292. Artedi, Ichth. gen. 64, syn. 90. Nau Schrift. der Berl. Naturf. 7.466. Schneid. Bloch, i.530, 1801. Pem. Brit. Zool. iii. 102, pl. 10, 1776-78. Shau, Gen. Zool. v. 251, pt. 2, pl. 133, 1804. Don. Brit. Fish. pl. 81, 1820-21. Flem. Brit. An. 163, sp. 1, 1827. Cuv. Règ. An. ii. 404, 1829. Mïll. Mém. de l'Acad. Berlin, 1834, 78, t. 4, f. 1, 5. Osteol. t. 9, 65, 67, 68, f. 9. Yarr. Brit. Fish. 2 ed. ii. 598,1841 .

Lamproie marbrée, Daub. Encycl. Méth. Bonn. Planches dIIist. Nut. de l'Enc. Méth.

Petromyzon maculosus, Artcdi, Ichth. gen. 64, syn. 90.

Petromyzon lamproie, Bloch, Hist. Nat. Poiss. 31, 77, pt. 13.

Petromyzon maximus, Cuv. Règ. An. ii. 118, $181 \%$.

Petromyzon, Klein, Mise. Pisc. iii. f. 30, n. 3.

Mustela sive lampetra, Belon. Aquat.76. Salt. Aquat. f. 62, 6 .

Lampetra major, Schwenck. Theriotr. Siles. f. 451 . Charlet, Onom.

f. 153, n. 3. Aldrov. 539, liv. 4, c. 13 . Jonston, liv. 2, tit. 2, e. 3, pl. 24, f. 5 .

Lamproie, Coms. Hist. Nat. v. 284. Fermin, Surin, 85. Rond. 310, pt. 1, lis. 13. Valmont de Bomare, Diet. Hist. Nat.

Lampetra Roudeletii, Lamprey or Lamprey-Eel, Will. Ichth. 10.5, pl. 2, f. 2, 1685. Ray, Syn. f. 35, n. 3.

Ioatzma unigi, Kompfer, Voy. au Japan, i. p]. 12, f. 2.

Il mustilla, Forsk. Desc. Anim. f. 18.

Plota thuti, Authors.

Lanpetra, lampreda kentmanni, lampreda, marina, mustela, Gesu. (germ.) 180, b. ct paralip 22.

Le Pétromyzon Lamproire, La Cepede, IIist. Nat. Poiss. i. 2, 3, pl. 1, 1798.

Lat Grande Lamproye, Cuv. Re'y. An. ii. 404, 1819.

Hab.-European Seas.

a. Siuffed. Firth of Forth. From Dr. Parnell's collection.

b. Stuffed. England.

c. In spirits. Coast of Devonshire. 
2. Petronyzox Jure. MacCulloch's Lamprey.

Petromyzun Jux, Mac C'ull. West. Isles, ii. 186, 187, t. 29, f. 1. , Sen. B. V. 1. 5.2.2.

Petromyzon fluviatilis, rar., Flem. Bril. An. 162.

HAB.-Coast of Scotland, east shore. Island of Jura. On the

Gray Gurnard. Specimen not preserved.

Probably a variety of $P$. marmus: the drawing of the teeth shows it bas no relation to $P$. flutiatilis.

3. P Petromyzon anericanes. American Sea Lamprey.

Petromyzon marimus, Schapffi. Beobachlmagen, tc. viii. 184. Witch. Tirans. Lit. o. Phil. Suc. i. 461.

Petromyzon americanus, Lesueur, Amer. Phil. Soc. (I. S.) i. 382.

Hist. N. A. Fish. ined. plate. Ftorer, Rep. on the Fishes of Massachusetts. De Kay, Nat. Hist. of New Fork, 379, pl. wi, f. 216, pt. 1. Zool. 1842.

HAB.-N. Anerica, Albany, New York.

a. In spirits. North America. From Mr. Brandt's collection

4. Petroujzon nigricaxs. Bluish Sea Lamprey.

Petromyzon nigricans, Lesuew, Amer. Phil. Soc. (N. S.) i. 385. Storer, Rep. on the Fishes of Massachnsetts. De hay, Nat. Hist. of New York, 3s1, pl.79, f. 247 (teeth indistinct).pt. I. Zool. 184?.

H.B.--N. America.

5. Petronyox anciextres. Silvery Lamprey.

Petromyzon argenteus, Kimland, Buston sozm. iii. 312, pl. 1, f. 3.

De Kay, Tat. Hist. of Yeu York, 382, pt. 1. Znol 1842. HAв.-N. America, River Ohio. 


\section{LAMPETRA.}

Upper inner tooth single, transverse, lunate, entire, with a conical fromincuce at each end. Lower inner tooth single, transverse, lunate, many-toother, outer lobe largest. Labial teeth unequal, the onter numerous, sinall, subequal, conical, in a single, submarginal series, the iuner larger, unequal; of the upper part small, in series; of the sides in a single series, larger, with two or three conical tubercles. Tongue with two compressed, pectinated teeth above, and a large, crescent-sliaped, transverse tooth below, crenated on the edge, and with a larger, conical projection in the centre, t. 1, f. 2. Yarr. Brit. Fish. fig. p. 604. De Kay, Nat. Hist. of $\mathrm{N}^{\top} \mathrm{W}$ York, t. 79, 249 (bad).

Petromyzon, sp., Limn., Cuv., Wiill.

Lampetra, sp., Ray.

Lampetra, Gray, Proc. Zool. Soc. 1851.

\section{* Dorsal fins separate.}

\section{Lampetra flctiatilis. Lampern or River Lamprey.}

Petrompyon fluviatilis, Linn. Bloch, pt. 3, pl. 78, f. 1, Linn. edit. de Gmelin. Miill. Prod. 3\%, n. 307. Aldrox. 587. Penn. Brit. Zool. v. pt. 106, pl. 10, 1776-78. Schneid. Bloch, 530, 2, 1801. Shaw, Gen. Zool. v. 257, pt. 2, 1s04. Don. Brit. Fish. pl. 80, 18:0-28. Flenn. Brit. An. 404, 1827. Cuv. Rèy. An. ii. 404, 1829. Mém. de l'Acad. Berlin, 78, 1834. Jen. Man. Brit. Vort. 521, sp. 210, 1835. Yarr. Brit. Fish. 2 cd. ii. 598, 1841. Parnell. Rich. Fatn. Bor. 294, 1836 .

Petromyzon fluriatilis, Cur. Règ. An. ii. 118, 1817.

Lamproie prycka, Daub. Encycl. Wéth.

Nein-oga natting, Fan. Suec. 106.

Petromyzon, Sc., Artedi, gen. 64, syn. 89, sp. 99.

La petite lamproie, B'och, 31 , pt. 3 , pl.78, l. 1 .

Ia lamproie branchiale, Bonn. Planches de l'Encycl. Méth.

Petromyzon, prick (negen-oog), Gronor. Mus. i. 64, n. 114. Zooph. 38.

Mustela, Plimy, liv. 9, c. 17.

Mustela fluriatilis, Belon, Aquat. 75.

Lampetra snbcinerea, maculis carcns, Salv. Aqaat. 62.

Lampetra, alterum genus, Gesn. Aquat. 597. 
Lampreda, Icon. Anim. 326.

Lampetra, medium genus, Will. Ichth. 106, tab. g. 2, 3, f. 1, 2 Ray, Syn. Pisc. 25, n. 1.

Lampetra tiuviatilis, Aldror. 587. Jonston, 104, pl. 28, f. 11. Schone, 41. Churlct, 159, 1. 7. Marseli, Dan. Pann. iv, 2, t. 1,1726 .

Lampetra fluviatilis, media, Schuenck. Theriotr. Siles. 532.

Jaatz me muagi, Kampfer, Voy. dans le Japan, i. 156, pl. 12, f. 2. Minog, Rzezynski, 134 .

Lamproie, Fermin, Hist. Nat. de Surinam, 85.

Petromyzon, Kramer, Elenchus, 38, 1. 1. Klein, Nisc. Pise. iii. $29,1.1$, t. 1, f. 3 .

Le Petromyzon pricka, La Cepede, Hist. Nat. des Poiss. i. 18, 1798.

HAB.-Europe.

a. In spirits. Thames. Presented by Mr. J. Doubleday.

$b, c$. In spirits.

ll. In spirits.

e. In spirits. Devonshire. Mus. Leach.

$f$.

2. Lampetra Plinert. Fringed-lipped Lampern.

Petromyzon planeri, Limn. Bloch, viii pl. 78, f. 3. Linn. edit. de Gmelin. Schneil. Bloch, 531, 532, 4, 1801. Shaw, Gen. Zool. v. pt. 2, p. 259, 1804 . Jen. Man. Brit. Vert. 522, sp. 211, 1835. Miell. Mem. de l'Acad. Berlin, 78, 1834. Cux. Règ. An. ii. 404, 1829. Yarr. Brit. Fish.2 ed. ii. 607, 1841. Lamproiea planer, Bonn. Planches de l'Encycl. Neth.

Le Petromyzon planer, La Cépede, Hist. Niat. des Poiss. i. 30, pl. 3, 1798.

HaB.-Europe.

a. In spirits. Firth of Forth. From Dr. Parnell's collection.

b. In spirits. Devonshire.

\section{* Dorsal-fin in contact with the second.}

3. Petronyzon Saxguisuga. Leech Lamprey.

Petromyzon Sanguisuga, La Cepede, Hist. Nat. des Poiss. ii. 99, pI. 1. Supp. to Petromyzon. Shaw, Gen. Zool. v. pt. 2, p. 261, 1804 . 
Petromyzon planeri, var. Cuv. Règ. An. ii. 118.

Haв.-Europe, Seinc.

A rery doubtful species; Curier says it is the same as the former.

\section{Lampetra Lamottexil. American Lamperu.}

Petromyzon Lamottenii, Lesueur, Hist. N. A. De Kay, Nat. Hist. of New York, 382, pl. 79, f. 249 (mouth), pt. 1. Zool. 1842.

HAB.-N. America, New York.

a. ? In spirits. North Amcrica. From the Paris Museum. P. fluviatilis, Mus. Paris.

\section{GEOTRIA.}

Upper internal tooth large, trausverse, crescent-like, divided into four lobes; the two inner lobes small, acute; outer truncated. The lower internal tooth transverse, narrow, slightly sinuous. The labial teeth numerous, far apart, conical, acute, in arched series, diverging from the throat; the innermost one larger, rest small; the innermost one of the lower part on each side, small, elongate, transverse, with two small, rudimentary tubercles. Tongue with two elongate, conical, arched teeth, with a triangular plate on the lower side of the base. Throat with a very large dilatable pouch, t. 1, f. 3 . Dorsal-fins two, far apart. Mouth very large, surrounded with ratber large, transverse, torn leares.

This genus chiefly differs from Velasia in the rudimentary state of the lower internal tooth, and in the form of the labial teeth, and in the large size of the oral disk, and the extraordinary development of the throat-pouch, which is found in a rudimentary state in the Petromyzon marinus This development of the pouch, is perhaps to adapt the animal to the long drought of the Australian rivers.

\section{Geotria australis. Pouched Lamprey. Tab. 2.}

Geotria australis, Gray, Proc. Zool. Soc. 1851.

HAB.-South Australia. Fresh-water.

a. In spirits. River Inkar pinki, South Australia. Presented by R. A. Pain, Esq. 


\section{VELASIA.}

Upper internal teeth Iarge, transverse, crescent-like, divided into four flat, elongated lohes; the onter lobes largest. The lower internal teeth large, transverse, crescent-like, convex, denticulated on the edge. The labial teeth very numerous, truncated, in crowled, arched series, diverging from the throat; the inner ones large, and gradually diminishing in size to the edge. Tongue with two very large, long, curved teeth, with a triangular plate beneath at their base, t. 1, f. 4. Dorsal-fins two, far apart. Mouth moderate, edged with transverse foliations.

Velasia, Gray, Proc. Zool. Soc. 1851.

1. Vejasia chulensis. Chilian Lampern.

HAB.-Chili. In fresh-water.

a. In spirits. Chili. Fresh-water.

\section{CARAGOLA.}

Upper inner teeth, two, large, separate, lateral, submarginal, each with three acute tubercles, Lower inner teeth large, crescentshaped, nine-lobed; the central and two lateral lobes on each side larger. The labial teeth in a subcircular, submarginal series, large, transverse, band-like, with three or four tubercles. Tongue with two flattened teeth, and a triangular, transverse plate below, with an acute process hetween the eeth on the upper edge, t. 1, f. 5. Dorsal-fins two, far apart.

Caragola, Gray, Proc. Zool. Soc. 1851.

\section{Caragola lapicida. Caragol.}

Silvery.

HaB.- - West Coast of America.

a. In spirits. Bay of Valparaiso.

\section{MORDACIA.}

Upper inner teeth two, separate, lateral, subtrigonal, each with three tubercles. The lower nine, conical, acute, in an arched series; the five central smaller. Labial teeth small, conical, in a 
single, circular, submarginal series, with a single, additional, odd tooth in the centre above. 'Tongue with two conical, arched teeth. Rich. Voy. Erebus \&. Terror, t. 38, cop. t. 1, f. 6.

Mordacia, Gray, Proc. Zool. Soc. 1851.

Petromyzon, sp., Rich. Voy. Erebus \&. Terror, t. 38, 1845.

1. Mordacin mordax. Australian Lampern.

Petromyzon mordax, Rich. Voy. Erebus \&. Terror, t. 38, 1845.

Mordacia mordax, Gray, Proc. Zool. Soc. 1851.

Hab.-Tasmania. Mus. Haslar Hospital.

Species of Doubtful Situation in the Tribe.

1. Petromyzon appexdix. Small Lamprey.

Petronyzon appendix, De Kay, Nat. IIist. of New York, 381, pl. 64, f. 211 , pt. 1. Zool. 1842.

HaB.-N. America, Hudson River.

"A ring of irregular sliaped corneous processes within the oral orifice, and a large isolated double tooth of the same texture on the inferior portion of the mouth." De Kay.

2. Petromyzon tridentatus. Tridentate Lamprey.

Petromyzon tridentatus, Gairdener, Rich. Fam. Bor. Amer. 293,

1836. De Kay, Nat. Hist. of New York, 381, pt. 1. Zool. 1842.

H.в.-N. America. Falls of the Walamet.

3. Petromyzon argenteus. Silvery Lamprey.

Petromyzon argentens, Bloch, t. 415, f. 2. Schneid. Bloch, 532, t. 102 , f. 1, 1801. Shan, Gen. Zool. r. pt. 2, p. 262, 1841. Ha1.-Indian Seas.

4. Petrouyzon bicolor. Brilliant Lamprey.

Petromyzon hicolor, Shaw, Gen. Zool. v. pt. 2, p. 263, 1804.

Petromyzon niger, La Cepcele, iv. 667.

$\mathrm{H}_{\text {A }}$.-Europe, Seine. 
5. Petromyzon plumbeus. Leaden Lamprey.

Petromyzon plumbeus, Shaw, Gen. Zool. v. pt. 2, p. 263, 1804.

Petromyzon septœil, La Cepede, iv. 667.

Har.-Europe, Seine.

b. Ammocœtina.-Teeth none; eyes none.

\section{AMMOCOETES.}

Teeth none.

Ammocotes, Dum. Zool. Anal. Cuv. Règ. An. ii. 118, 1817. Mïll. Abhandl. Akad. Berlin, 1834, 78. (1836).

? Lampreda, Rafin. Anal. Nat. 94, 1815.

1. Amuocates branchials. Pride or Sandpiper.

Ammocœtes branchialis, Dum. Flem. Brit. An. 164, sp. 3, 1828. Cuv. Règ. An. 406, 1829. Müll. Mém. de l'Acad. Berlin, 1834. Jen. Man. Brit. Vert. 522, sp. 212, 1835. Yarr. Brit. Fish. 2 ed. ii. $609,1841$.

Petromyzon branchialis, Linn. édit. de Gmelin, 1815. Bloch, pt. 3, pl. 78? f. 2. Lim. Faun. Suec. 292. Wulff. Ichth. Borus. 15, n. 20. Miill. Prod. Zool. Dan.37, n. 307, b. Kramer, Elench. 483. Penn. Brit. Zool. iii. 107, pl. 10, 1776-78. Shax',

Gen. Zool. 260, 1804.

Petromyzon corpore annuloso, Sc., Artcdi, gen. 42, syn. 90.

Lamproie branchiale, Bonn. Planches de l'Encycl. Daub. Eucycl. Méth.

Petromyzon, Gronov. Zooph. 38, n. 160. Klein, Mise. Pise. iii. 30, ก. 4 .

Petromyzon crecus, Cuuch, Mag. Nat. Hist. v. 23, f. 60.

Mustela finviatilis, Gesner, Aquat. 589. Icon. Anim. 286. Thierb. $159, b$.

Lampetra minima, Aldrov. 539.

Lampern, or Pride of the Isis, Will. Ichth. 104.

Pride, Plot, Flist. of Oxford. 182, t. 10.

Lampetra cæca, Will. Ichth. tab. g. 3, f. 1. Ray, Syn. Pisc. 35, u.

2, 4. Couch, Loudon's Mag. Nat. Hist. v. 23, 1. 9-10.

Iampreta neunange, Jonston, t. 28, f. 10.

Lamproyon et lamprillon, Rond. Hist. Poiss. ii. 202. 
Querder, schlamquerder, Schwenchf. Theriotr. Siles. 423.

Der Kierferwurn, Miill. l. c. iii. 231.

Iampreyon, Valmomt de Bomere, Dict. Hist. Nat.

l.e Petromyzon lampreyon, La Cepede, Hist. Nat. des Poiss. i. 26, 1). 2, f. 1, 1798 .

Hเs.-Enrope. Rivers.

n. In spirits. Sardinia. Presented by Professor Bonelli.

b. In spirits. Eton. Mus. Leach.

c. In spirits. Young. River Annan. From Dr. Parnell's collection.

2. Ammocates rueEr. Red Lamprey.

Ammocetes ruber, Cuv. Règ. An. 406, 1829. Mïll. Mém. de l'Aear. Berl. 7., 1834.

Petromyzon ruher, La Cepede, Hist. Nat. des Poiss. ii. 99, pl. 1. Suipp. to Petromyzou. Shau; Gen. Zool. v. pt. 2, p. 261. 1804 .

Ammocœtes branchialis, var., Cuv. Règ. An. ii. 118, 1817. Haв.-Europe, Seine.

3. Amsocotes concolor. Mud Eel or Blind Eel.

Ammocotes concolor, Kirtland, Boston Journ. iii. 473, pl. 27, f. I, $a, b ., 184]$.

HAв.-N. America, Mahoning and Scioto Rivers.

4. Amuocetes bicolor. Coloured Mud Lamprey.

Ammocotes bicolor, Lesueur, Amer. Phil. Soc. (N. S.) i. 386.

Ammoeœtes bicolor, Stover, Fishes of Massachusetts, 198. De Kay,

Nat. Hist. of New York, 383, 679, f. 248, pt. 1. Zool. 1842.

Ha в.-N. America, Connecticut Rirer.

5. Amyocates unicolor. Plain Mud Lamprey.

Ammocœtes unicolor, De Kay, Nat. Hist. of Neu York, 383, pl. 79, f. 250, pt. 1. Zool. 1842 .

HaB.-N. America, Lake Champlain. 


\section{Fam. 2. MYXINIDE.}

Palate perforated.

Myxinia, Rafu. Anal. Nat. 94, 1815.

Petromyzonidæ (Gastrobranchini), Bonap. Syst. Ichth. 1838, 14.

Cyclostomata hyperotreta seu Myxinoidea, Miill. Abhandl. Akad. Berlin, 1834, 78. (1836).

Petromyzidæ, 3., Gray, Syn. B. M. 1842, 14\$, 150.

\section{Symopsis of Genera.}

1. Mrxine.-Branchial spiracles connected externally.

2. Bdellostom.-Branchial spiracles separated externally.

\section{MYXINE.}

Branchial spiracles connected externally.

Myxine, Limn. Syst. Nat. Gunner, Drontheim Gesell Sehrift. ii. 230, t. 5. Rnfin. Anal. Nat. 94, 1815. Cur. Rèy. An. ii. 118, 181\%. Miill. Alhandl. Aliad. Berlin, 1834, 79.

Gastrobranchus, Bloch.

Petromyzon, sp., Walb. Artedi, ii.500.

Myxine was arranged with the Termes by Linneus. It was tirst removed to the fish by Retzius (Nov. Act. Reg. Acad. Sipe. 179. Anim. Pisc. 17, 1800. Berlin, Schrift. Nat. I. T. xii. 193, 244. Bloeh, Ausland Fische, ix. 67.

1. Mrxise glutivosa. The Mrxine.

Myxine glutinosa, Linn. Syst. Nat. Mus. Rey. Adolph. Fred. t. 4, f. 11, t.9, f. 3. Wiill. Prod. Znol. Dan. 227. Sthrift. der Berl. Gesselsch. Naturf. 10, 193, 244, t. 4. Flem. Brit. An. Wort. 523, sp. 213, 1828. Miill. Mém. de l'Aead. Berlin, 1834, 79, 336, t. 2, 3, f. 8, 9. tah. ix. Jen. Brit. An. Iert. 523, 213, 1835. (Sleep Marten), Gunner, Drontheim Gesell Schrift. ii. $230, \mathrm{t} .3$. 
Gastrobranchus cacus, Bloch, pt. 12, 413. Penn, Brit. Zool. iii. 109, 1776-78. Shaw, Gen. Zool. ii. 264, pt. 2, pl. 134, 1804. Cuv. Règ. An. 2 ed. ji. 406, 1829. Yarr. Brit. Fïs. 2 ed. ii. 612,1841 .

Lampetra cæca, Will. Ichth. Kalm, North America, 145. Petromyzon Myxine, Walb. Artedi, ii. 500.

HaB.-Europe.

a. Stuffed. Firth of Forth. Frum Dr. Parnell's collection.

b. In spirits. Yorkshire. Presented by the Rev. J. Dalton.

c. In spirits. Norway. Presented by - Woodfall, Esq.

\section{BDELLOSTOMA.}

Branchial spiracles separated externally.

Gastrubranchus, Bloch. Rafin. Anal. Nat.91, 1815.

Bdellostuma, Miill. Abhandl. Akad. Berlin, 1834, 79, 1836, 1841, 111,1844 .

Heptatrema, Dum. Zool. Anal. Cur. Règ. An. ii. 40.

* IVith six apertures on each side.

1. BDEllostoma hexatrema.

Bdellostoma hexatrema, Müll. Mém. de l'Acad. Berlin, 79, 1834.

HaB.-Sonth Seas.

** IIth six openings on the right, and scren on the left side.

2. BDELLOSTONA HETEROTREMA.

Bdellostoma heterotrema, Mill. Mém. de l'Acad. Berlin, 1834, 79, t. 1, 6, 7, 8. Anat. t. 3,9, f. 1, 4, 7 .

HıB.-South Seas.

*** With seren apertures on cach side.

3. Bdellostoma heptatreni.

Bdellostoma heptatrema, Müll. Mém. de l'Acad. Berlin, 79, 1834. Fish, Home, Phil. Trans, t. 12, f. 1, 258, 263, 1815.

HA B.-South Seas. 
4. Bdellostoui Forsterii.

Bdellostoma Forsterii, Mïll. Mém. de l'Acad. Berlin, 80, 1834. Petromyzon cirrhatus, Forst. Bloch, Syst. Ichth. Schneid. Bloch, $55^{2}, 1801$.

Heptatremes cirrhatus, C'uv. Rèy. An. 2 ed. ii. 405, 1829.

HAB.-New Zealand.

**** Doubtful Species.

\section{Boellostoma Dombeyi1.}

Bdellostoma Dombeyii, Miill. Mém. de l'Acad. Berlin, 80, 1834.

Le Gastrobanche, Dombey, La Cepede, Hist. Nat. des Poiss. i. 531, pl. 23, 1798.

Heptatremes Dombeyii, Cur. Règ. An. ii. 405, 1829.

$\mathrm{H}_{\mathrm{AB} .-C h i l i .}$

\section{Fam. 3. AMPHIOXID王.}

Amphioxidæ, Gray, Syn. B. M. 1842, 150.

Condropteringi a branchie esterne, Costa, 1834.

\section{BRANCHIOSTOMA.}

Branchiostoma, Costa, Fauna Regno Napoli, 1832, 1836, 1, t. 30. Annuario Zoologica, per l'Auno 15:34-49. Müll. Abhandl. Akad. Berlin, 1841, 79.(1844). Mlonat. Bericht. Akad. Berlin, 1842.

Amphioxus, Gray, in Yarr. Brit. Fish. 468, 1836. Sunder. \& Loucn, Forsk. Skand. Naturf. 1838. Kiövenh. 1841, 280. Retzius, Monat. Bericht. Akad. Berlin, 1839. Goodsir, Ann. Nat. Hist. vii. 346, 1811. Trans. Roy. Soc. Edin. xvi. 1. 1841. (Anat).

Limax, sp., Pall. Spic. Zool, x. 19, t. 1, f. 11. 


\section{Branchiostoma lubicun.}

Brachystoma luhricus, Costa, Cenni Zoologici, 49, 1834, 12 mo. Nipoli.

Branchostoma lubrieum, Costa, Fauma Regno Napoli, i. t. 30, 1832. 1836, (1 839, fide Miuller). Miill. Abhandl. Aliad. Berl. 1841, 79, t.1-5, 1844. Monat. Bericht. Akad. Berl. 1842.

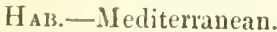

a-e. In spirits. Naples. Presented by Professor Kolliker.

2. Branchiostona lanceolatum. Lancelet.

Amphioxus lanceolitus, Couch, Mag. Nat. Hist. 1838. Cornwall Fauna, 5̃. Yarr. Bit. Fish. 2 ed. ii. 618, 1841. Limax lanceolatus, Pall. Spic. Zool. x. 19, t. 1, f. 2 . Haв.-S.-W. Coist of England.

a. In spirits. Polperro. Presented by J. Couch, Esq.

3. Branchlostona Belcheri.

Amphioxus Belcheri, Gray, Proc. Zool. Soc. 1847, 355. Hab.-Iudian Ocean.

a. In spirits. Borneo. Presented by Capt. Sir Edward Belcher, R.N., K.C.B., \&c. 


\section{ADDITIONS AND CORREC'TIONS.}

\section{Page 1,}

After Pisces Chondropterygii, add Artedi, Gen. (i4, 173r.

$$
\text { Page 3, }
$$

After Gills free, add as in other fish, covered with an operculum, with a single opening, but without any rays in the membrane, aud add

Eleutheropomes, Dum. Zool. Anal. 185, 1806.

$$
\text { Page 9, add }
$$

9.*Acipenser calibonarics. The Black sturgeon.

Acipenser carbonarius, Agassiz, Lake Suproior, t. 5.

Hab.-N. America, Lake Superior.

$$
\text { Page 13, }
$$

For 12. Aclpenser Atulus, read Acipexser Sturlo.

$$
\begin{gathered}
\text { Praye } 22 \text {, after } \\
\text { Section C. PLAGIOSTOMIA, }
\end{gathered}
$$

Add Gills peetinate ; pectoral and ventral-fins distinet. Body flattened.

$$
\text { Page 37, }
$$

2. Nebrius cirratum, add

d. Stuffed, adult. West Indies. From the Zoological Society. 
1. Secales gratces, add

$$
\text { Page 44, }
$$

g. Stuffed. Gibraltar. From the Zoological Society.

$$
\text { Page 45, add }
$$

4.* Soualus (Carcharines) obrelatus. The Veiled Shark. Prionodon obvelatus, Valene. in Webb, Berth. Canar. Weigmann, Arch. ii. 201, 1845.

Haв.-Canaries.

$$
\text { Page 46, }
$$

10. Squalus leucas, add

a. Stuffed. Presented by the Lords of the Admiralty. From the Antarctic Expedition.

$$
\text { Page 47, }
$$

17. Soualts Mexisorrah, add

b. Stuffed. Cape of Good Hope. From Dr. Andrew Smith's collection. In the Zuolugical Suciety.

$$
\text { Page 48, }
$$

20. Squalus Temminceir, add

Carcharias Yarrellii, Müill. \& Henle, MSS. Cat. Zool. Soc. ii. 662.

b. Stuffed. From the collection of the Zoological Society.

C. Yarrellii, Miull. f. Henle, MSS.

$$
\text { Page 58, }
$$

1. Mustelus velgaris,

Erase the reference to Mustelus equestris, and add

1.* Mustelus equestris. The Mediterranean Hound-fish. Mustelus equestris, Bonap. Fann. Ital. t.

H.B.-Mediterranean. 
Page 62,

Erase Rineodon, Smith, Mag. Nat. Hist. 5, 1838?

Page 80, add

1.* Squatina oculata.

Squatina oculata, Bonap. Faun. Ital. t.

Page 101,

Torpedo naruorata, add

Lophius monopterygius, Shaw, Nat. Misc. t. 202, 203 (badly stuffed).

5. Torpedo TrEpidana.

Torpedo trepidana, Valenc. in Webb, Berth. Canar. t.

HaB.-Canaries.

\section{Page 102, after NaRcine, add 2.* DISCOPYGE.}

Body discoidal. Disk orbicular. Mouth transverse, furnished near the angles with thickened lips: jaw with a dental plate in the middle, inflected on the outside; the smallest teeth arranged in a quincunx. Teeth flat, rlomboidal, with the posterior angle sharp. Velum behind the npper and lower jaw. Nasal-valve truneated, furnished in the middle with a sinnated process, connected beneath with the circular fold of the mouth by a fremulum. Spiracles arljacent to the eyes, with a naked margin. Ventral-fins connected below the tail. Dursal-fins two, equal. Candal-fins obliquely oral.

Discopyge, Hcckle, MSS. Tschudi, Faun. Perue. Erichson, Arch. Naturg. 367, 1847.

1. Discopyge Tschudit.

Discopyge Tschudii, Hecklc, l. $c$.

НА в.-Peru.

Page 105, line 12,

For Propleysia, read Propterygia. 


\section{Page 108, add}

8*. Raja bramayte.

Lævoraga bramante, Sassi, Nuovi Anal. Scienze Nat. Bologna, vi. 1816,386 .

HAB.-Mediterranean.

$$
\text { Page 118, }
$$

Trigon pastinaca, add Bonap. Faun. Ital. t.

$$
\text { Page 119, }
$$

Trigon Brucco, add Bonap. Faun. Ital. t.

$$
\text { Page 121, }
$$

For Uroxis rigo, read Uroxis Ujo. 


\section{N D E X .}

\section{A。}

\section{Acanthias, 69} acanthias, Sq. 70 Acanthidium, il acanthius, Galeus, 21 Acanthorhinus, 73 Acanthorinns, 69 Acanthorrini, 69 Acantiana, 40 Acipense, 1] Acipenser, 4 Acipensere, 7 Acipenseres, 6 Acipenseridæ, 4 Acipenserini, 4 aculeata, Raja, 106,110 ,$S_{q} .80$ aculeatus, Ac. 12 acutidens, $\mathrm{Sq} .43$ acutus, Carch. 41 Adano, 13 adspersa, Rhinopt. 132 Etobatus, 1:2 Etoplatea, 1:7 affinis, Ac. 8 Africanum, Pojod. 31 , Scyll. 31 Africanus, Scylliorh. 31 "Urogym. 115

Agassizii, Urajt. 11 t

A iereba, Tryg. 117

Akajei, Tryg. 120 alalonga, Carch. 45 alba, Raja, lok; Albert, Huso, 17 albimarginatus, Sq. 46 Allrovandi, T'ryg. 119 Aleutensis, Ac. $x$ Alopeciæ, 63 Alopeciana, 39 Alopiana, 63 Alopiatiui, 63, 6f Alopias, 64 altavela, Dasy, 122 alterum genus, Zamp. 140 amboinensis, $\mathrm{Sq} .45$ americana, Raja, 112 " Torp. 96 americanus, Petrom. 133 americanus, Siq. 75

Ammocotes, 145

Ammocoetina, 137, 1.15

Amplioxidie, 119

Amphioxus, 150

Anacanthes, 117

Auacanthi, 114

Anacanthis, 114

Anacanthus, 114

Ancantianit, 69

ancyclostomus, Rlina, 92

Augelina, Sq. 8u

angelus, $S_{4} \cdot 80$

anglostoma, Libina, 98

anisodon, sy. 88

annulatus, líti nob. 94

Antacea, 24 Sq. 32

Antacei, 11

Antacens, ?

antarctica, Callor. 22

antiquorum, Pristis, \$

appendiculatus, Sq. 3 t appendix, Petrom.1.14 Apterurus, 133

aquila, Mrliob. 19r Arcticus, Galeoc. 54 argenteas, Chein. 21 argenteus, Petrom. 139, 14

argus, $\mathrm{S} q .37$

Aristoletis, Canicula, $\leqq 9$ armatus, Iibinob. 96 , Tryg. 126; Arnak, Raja, 116 Artedi, Scyllium, 32 aspera, Ritja, los aspera, ast., Raja, 107 asperrima, liaja, 115 asperrimus, Crogym. 115 asterias, fial. 56 , liaja, 108 Astrape, 1 43 atlanticus, Ac. 15 atra, Raja, 105 Atillus, Ac. 13, 14 aurantiacus, Tryg. 126 auriculata, Mob. 133 australis, Chimæra, 22 " Geotria, 142
B.

Bancroftii, Tolp. 102 Banksii, Fhinob. 95 batis, Diph. 110 Raja, 110 barattula, Raja, 106 barbatus, Cr. 36

$$
\text { " Sq. } 36
$$

Bdellostoma, 1.1 N Belcheri, Branchyost. 150 Bellonii, Ichtbyoc. 17 Beluga, 17

Bennetti, Tryg. 11 $\mathrm{N}$ bicolor, Ammo 146 "Petrom. 144 " Raja, los biocularis, Raja, 109 bispinatus, $\mathrm{Dal}, 77$ bivium, sierll.31 Blainviliii, A canth. 70 Blocbii, Rlínou, 94 , Sphyrn. 50 Bonaparti, sympt. 113 bonasus, liaia, 13\% borealis, Dal. it Borysthenis, Anct. 17 Bouganvillii, Fhinob. 95 bovina, Mrliob. 128 lirachystoma, 150 branchialis, Amm. 145 Branchiostega, Ch. 3 Branchiostoma, 149 Branchismea, Chism. 20 Branchostoma, 150 Brasiliensibus, Cue. 50 urasiliensis, Narcine, 102 $\begin{array}{ll}, & \text { Raja, 113 } \\ , & \text { Rhinopt. 131 } \\ \text { Scymus, 76 }\end{array}$ brevipinna, somn. 7 brevipinmus, Sq. +2 brevirostris, Ac. 11, 15 , Rhinob. 94 brevirostrum, Ac. 15 brevissimis, fialeus, 29 Liucco, Tryg. 119 Burgeri, scyll. 30 
C.

cicca, Lamp. 145, 1.18

crecus, Gastrob. 118

"Petrom. J 45

cæruleus, Sq. $\$ 4$

calceus, Acanth. 74

californica, Triakis, 56

Callorhynchus, 2】,22

Camensis, Ac. 8

canariensis, Dusy. 122

canicula, Scylli, 29

,$\quad \mathrm{Sq} .29$

Tollo. 29

caniculata, Prist. 89

caniculum, Scyll. 29

caniculus, Scylliorh. 29 Sq. 29

canis, Galeus, 5:

$$
\text { ,Sq. } 57
$$

cap̧ense, Scyll. 31

capensis, Astr. 103

, Carch.61

" Raja, 112

Caragola, 143

Carcharhinus, 46

Carcharias, 4l

Carcharius, 44

Carcharodon, 60)

carens, Ituberc., Ac. 17

carnea, Tryg. 12]

cartilarinei, Plag. 23

cataphracta, Bracl. 4

cataphractes, Ac. 18

Catulus, 28, 29

$$
\begin{array}{ll}
" & \text { Scyll. } 30 \\
\text { Sq. } 32
\end{array}
$$

caudata, Sq. 41

Centrina, 21, 71 "Oxyr. 72

Centroscyllium, 74

cepedianus, Gal. 54

Cephaloptera, 1:33

Cephalopteræe, 133

Ceratoptera, 134

cerniculus, Rhinob. 96

Cestracion, 49

Cestraciontes, 65

Cestrorliuus, 48

Cetorhinus, 6]

chagrina, Raja, 110

chagrinea, Raja, J10

cbuntenay, Rair, 111

chilensis, Velasia, 143

('hiloscyllium, 34

Chimaralıe, 20

Chimaridæ, 20

Chimera, 20

Chimera, 21

Chimaradie, 21

Chimariui, 20

Cbimeria, 20

chineusis, Ac. 6
Chismopnea, 20

Chismopnes, 20

Chondrostei, 3

cinereus, fial. 30

, Hepta. 68

, Sq 30

circularis, liaia, 10.5

cirratus, prist. 88

cirratum, Neb. 37

" Ging. 37

cirrhatus, Petrom. 149

,$\quad$ Sq. 37

cirrhesum, Seyll. 37

clavata, Raja, 106, 107

, Squatinor. 106

Colliei, Chim. 21

Columna, Rhinob. 94

concolor, Amm. 1.t5 Neb. 37

cordisfigura, Cestra. 50

cornubicus, Sq. 59

Coruuda, 49

crabuda, Raja, 107

Crossorbinus, 35

cruciata, Raja, 126

cruciatus, Leiob. 126

Cururi, 50

cuspidatus, Prist. 90

Cyclostomata, $\mathbf{1 3 6}$

Cvelostomes, 136

Cyclostomi, 136

Cyclostomia, $13 t^{\circ}$

D.

Dalatiana, $40,7.1$

Dalatias, 75 ,

Danubii, Huso, 17

Dasyatis, 121

Dasybatus, 105, 116

Damicus, Ac. 16

Dayatis, 119

Delarochianus, Scylliorh. 32

Diabolus, 135

Diaphaues, Raja, 113

Dicerobatis, 133

Dinectes, 18

dipterygia, Astr. 103

Dipturus, 105

Djedlensis, Rhinob. 93

Dombeyii, Bdell. 149

donensis, Ac. 10

dubius, Ac. $?$

Duhameli, Rhinob. 93

Dumerillii, Sq. 80

Dussumieri, Sq. 47

E.

Echinorlinus, 77

Echinorrhinus, 78 edentatus, Sq. 135

edentula, Platiros. 20

Edwardsii, Sevll. 28

Eel-Tenkee, Myliob. 1:30

eglantiesa, Raja, 107

Ehrenbergii, Cerat. 1:34

Elasmobranchii, 3

electricus, Rhinob. 96

elephas, Sq. 6I, 62

Eleutheropoma, Ch. 3

Eletutheropomes, 3

Eleutheropomi, 3

Elipesurus, 12]

Elops, 9

Eltropomia, 3

emarginata, Torp. 100

ephippiatus, Tryg. 126

episcopus, Myliob. 129.

erinaceus, Raja, 112

europæus, Ac. 14

exoticus, Galeus, 2]

F.

Fabricii, Centr. 7.

fabroni, Aptern. 133

fabroniana, Raja, 133

falciformis, $\mathrm{Si}_{1} .47$

falcipinnus, Carch. 45

falsavela, Raja, 105, 107

fusciata, Trig. 98

fasciatum, Steg. 38

fenestrata, Raja, 106

ferox, Odont. 63

fimbriata, Sq. 80

fissidens, Carcb. 47

flagellum, Ai tob. 130

flossada, Raja, 110

fluta, Plota, 138

fluviatilis, Iamp. 140

, $\quad$ Must. ]45

folium, Polyodon, 20

Forskalii, Tryg. 123

Forsterii, Bdell. 14!

Fremenvillii, My liob. 132

fullonica, Raja, ]07, 1109

fuscus, Spinax, 71

G.

fialeocerdo, 53

Galeorhinus, 52, 55

Galeus, 12, 52

Galieana, 39,52

Galii, 52

Galvanii, Torp. 101

gangeticus, $\mathrm{Sq} .45$

Ganiouis, 78

Ganodus, 21

Ganoidea, 3 
(iarrapi, Tryg. 124

Gastrobranchus, 147

(iata, 37

Geckelii, Ac. 12

Georgianis, Lausa, 10

Geotria, 14?

Gevaril, Tryg. 116

Gesneri, Huso, 17

Tryg. 118

Ginglymostoma, 37

Giorna, Cephal. 131

glaber, $\mathrm{Ac}, 6$

glacialis, $\mathrm{Sq} .77$

glauca, Oxyr. 60

glaucostictus, Khinob, 90

glaucus, Sq. 44

glutinosa, Myx. 147

glyphis, Sq. 45

Gmelini, Ac. 7

gomphodon, Oxyr. 60

granulosa, Prist. 8!

Grabatus, Tou. 125

granulatus, Rhinob. 95

granulosa, Iiaja, 110

granulosus, Acanthor. 75

$$
\text { , Centr. } 71
$$

griseum, Chil. 35

griseus, Hexa. 17

Gunneri, Cetorh. 61 ,$\quad$ Sy. 77

Guldenstadtii, Ae. 11, 12

guttata, Kaja, 117

gymnura, Tryg. 119

H.

Halavi, Rhinob. 95

Halgani, Tryg. 124

Harilwickii, Tem. 104

hastata, Tryg. 121

Heckelii, Ac. 12

Helminthoidei, 136

Helops, Ac. 12

Helopes, 4, 8, 9

heuniodon, Sq. 43

Hemiscyllium, 33

Hemitrygon, 118

Henlei, $\mathrm{S} 4.47$

heptagonum, Scyll. 39

Heptanchus, 68

Heptatrema, Bdell. 148

Heptranchus, 68

Heterodontina, 40, 65

Heterodontus, 05

Heterotrema, Bdell. 148

Hexanchina, 40

Hexanchus, 6 ?

Hexatrema, Buell. 14i

Himantura, 116 hinnulus, Gal. 56

Holocephala, Ch. 3,20

Holocepliali, 20

Homianus, Cetorh. 62

Horkeli, lihinob. 97

huilsonicus, Ac. 15

humilus, Sq. 57

Huso, 15, 17

$$
\text { ,Ac. 11, 13, 15, } 17
$$

"Husones, 17

Husones, 15

husoniformes, Ac. 16

Hynniceptalus, Rhinob. !17

Hyperoartia, 136

Hy polophus, 123

Hy poprion, 43

hystrix, Tryg. 120

Ichthyocolla, Ac, 18

Ichthyocolle, Ac. 17

imbricata, Tryg. 119

Iudianus, Urol. 125

indica, Narc. 102

indicus, Hepta. 68

infernus, Sq. 71

intermelia, Raja, 111

Ischyodon, 21

Isodun, $\mathrm{Sq} .43$

isodus, $\mathrm{Nq} .6 \%$

Isurina, 39

Isurus, $45,58,59$

J.

Jabebara, Tryg. 117

Jabehirite, II?

jamaiceusis, Raja, 125

Japanica, Cephal. 134

$J$ apanicus, Galeus, 53

J aponicus, 1)asy. 122

Javauica, Rhinopt. 132

Jeinorni, Past. 126

Joatzma, 134

Johnii, Cerat. 134

Jurce, Petrom. 139

Jussicu, Myliob. 13]

K.

Kaluschia, Ac. 16

Kamensis, Ac, 8

Kenojei, Raja, 112

Kotsege, Sturio, 7

Koma, $\mathbf{4 9}$

Koster, 7

Kostera, 7

Ac. 12

Kuhlii, Cephal. 134

, Tryg. 120
1.

Labordii, seym. 77

Lituargus, $70^{\circ}$

Leviraga, 105

hevis, Gal. $56^{\circ}$

, Must. 57

, liaja, 106, 108, 109

, Rhinob. 93

lagenarius, Ac. 16

Laiandii, Rhinop. 131

$$
, \text { sq. } 42 \text {. }
$$

Lamia, Sq. 41

Lamana, 44, 58

Lamanæ, 58

Lamnojdea, 58

Lamnoidia, 66

Lamottenii, Lamp. 142

Lampetra, 140

Lampreda, 141

Lampredia, 136

lauceolatus, Amph. 150

lauceolatum, Branch. 150

Lansa, 10

lapicida, Car. 143

laticaudus, Carch. 41

laticeps, $Z_{y g} .50$

latirostris, Ac. 15

Leiobatus, 104, 125.

Lemprieri, Raja, 112

Leopardinum, Scyll. 31

Lepidorhinus, 73

Leptochariana, 39

Leptocharias, 51

leucas, $\mathrm{Sq}$. 46

Lewisii, Zyg. 49

Libella, $4 \dot{8}$

Lichia, Dal. 75

Lichtensteinii, Ac. 14

Limax, 149

limbatus, $\mathrm{Sq} .48$

lingula, Narc. 102

lintea, liaja, 111

Liouisci, 6

littoralis, Carch. 60

lobatum, Scyll. 36

lobatus, $\mathrm{Cr} .36$

$$
\text { , } \mathrm{sq} .36
$$

longa, Galeus, 64

longicaudus, Sq. 38

I.oxodon, $5 \pm$

lymna, Trn. 121

Trvg. 119

lubricum, Branch. 150

lubricus, Brachyst. 150

lutescens, Ac. 13

\section{M.}

Macloti, Sq. 43 maclura, Dasy. 15 
materensis, IRaja, I06 macroceptala, Raja, I2y macrojthalmus, Ac. 11 nacrorbinus, Loxo. 51 macrorkynchus, Lieviraja, 109

macrostonus, Ac. 16 Raja, 110

macrourus, Alop. 64

Inaculata, liaja, 101, 108, 104

maculata, Torp. 100

muculatum, Scyll. 28

maculatus, Ac. 15

$$
\text { " Myliob. 129 }
$$$$
\text { " Proc. } 19
$$

maculosus, Petrom. 138

$$
\begin{gathered}
\text { major, Cat. } 30 \\
\text { " Galeus, } 29 \\
\text { Lamp. } 138
\end{gathered}
$$

malaianum, Chil, 35

malaisanum, Scyll. 35

malleus, Zyg. 49

Muou, Sq. 46

marina, Aquila, 128

,Past. 118, 125, 128

¿ Serra, 89

, Simia, 21

"Vulpes, 64

marinus, Diab. 135

, Petrorn. 138, 139

marginata, Raja, I08

$$
\text { "Rbinopt. } 131
$$

marginatus, Ac. 15

Marcgravi, Rhinob. 96 marmorata, Torp. 100 marmoratum, Scyll. 28 marnoratus, Cat. 28 maroccana, Raja, 112

Marsiclii, Ac. 6

Massena, Raja, 133

Mattino, Ac. I3 mauritianus, Scymn. 77 maxima, Selache, 62 maximus, Cetorh. 61

Maxinia, 147 Petrom. 138

megalopterus, Must. $5 \mathrm{k}$ medium genus, Lamp. 141 medius, Ac. 11

melanopterus, Sq. 46 melanostomum, Prist. $3: 3$ melanostomus, Prist. 32 melastomus, Gal. 32

$$
\text { , Scylliorh. } 32
$$

Menisorrah, Sq. 47

Meyeni, 'Trn. 124

Inicrocellata, Raja, 1 ry

microcephalus, Sq. 77

oicrodon, Prist. 90

Micrognati, Po. 3 unicropterus, Scywn. 77

micrura, Dasy. 122

Milberti, Sq. 45

Milous, Hyliob. 12y minor oxyr., Raja, 108 minor Tib., Sphyr. 50 minor stell., Gal. 30 miuima, Laınp. 145 miraletus, laja, 108 monstrosa, Chim. 21 Mobula, 133

Mobular, 135

Mottarran, Sphyrn. 51 monge, Not. 68 monensis, $\mathrm{Sq} .59$

Monopterbinus, 67 monopterygio dorso, liaja, 103

Mordaeia, 143

Mordax, II ord. 144

mosuica, Raja, 106

motoro, Tren. 125

mucosissima, Levir. los

micronata, Raia, 109

Mulleri, Sq. 42

Iullerii, Trig. 63

muricatus, Ac. 16

Musteliana, 3!

Musteli, 56

Mustelini, 56

Mustelus, 56

Myliobatides, $: 27$

Myliobatis, 127

Myxine, 147

Ml yxinida, 147

Myxinoidea, 147

N.

Naccari, Ac. 13

nævus, Raja, 107

Narcine, lol

Narcobatus, 99

Narinari, Paja, 130

nasuta, Raja, 112

Nebrius, 36

niceen, $\mathrm{Sq} .6$

Nieuhofii, Mlyliob. 129

niger, Fetrom. 144

"spinax, 71

nigra, Centr. 72

nigricans, l'etrom. 159

neunange; lamp. 145

nobiliuna, Torp. 100

noctula, Myliob. 128

norwegianus, $\mathrm{Sq} .77$

Notidiani, 67

Notidianini, fi7

Notidanus, 65

nudiventris, Ac. $t$
P.

U.

obesus, Echinorh. 78 , Lept. 51

obscurum, Chil. 35

obseurus, $\mathrm{Sq} .47$

obtusirostris, Ac. 15

obtusus, 12binob. 97

ocellata, Raja, 111

Torp. 102

ocellatum, Hemisc. 33

ocellatus, Sq. 33

oculata, laja, 108, 109 , 113

oculata, Torp. 99

oculeus, M Ifliob. 129

Odontaspidiana, 39, 62

Odontaspis, 62

Etobatis, 130

obiensis, Ac. 16

OHfersii, Cephal. 133

orbicularis, Raja, 117

Orectolobus, 34

orientalis, Ac. 16

ornata, Tryg. 124

ornatum, Orect. 34

osteosticta, Tryg. 119

Oxynotus, 72

Oxyrbina, 59

oxyrbynchus, Ac. 8 ,) Is. 59

, Sq. 45

" Raja, 108, 111

oxyriuchus, Ac. 8

Pado, Att. ]:

pæecilura, Raja, 122

precilurus, Tryg. 122

pantbera, Torp. 101

pantherinum, Scyll. 31

pantherinus, Heterod. 60

pardus, Scyll. 28

Pastinaca, 118

Pastinacas, 118

Pastinace 2 , 115

pectinate, Prist. 90

pectinatus, Prist. 90

peculiaris, Att. 13

Pejegallo, 2:2

Perotteti, Prist. 9u

l'etromyzidde, 136

Petroinyzon, 137

Petromyzonide, 136

Petromyzonini, 136

Philippi, Hetero. 6t;

IRhinob. 96

I'by'sorion, 42

pieta, Raja, 106 
pictum, scyll. 28 pictus, $\mathbf{S q} .28$ piscis, Graleus, 53 Plagiostomata, 23 Plagiostomes, 22 Plagiostomia, 22 Plagiostomi, 23 plagiosum, Chil. 34 , Ovect. 34 , Scyll. 34

planeri, Petrom. 141 planirostra, 19 platorhynchus, Ac. 18 Platosomia, 81 Platy cephalus, Ac, 13 Platyrhina, 98 platyrhynchus, Ital. 55 pleibius, Must. 57

Plinius, Mario, 17 Plota, 138

plumbeus, Petrom.145

Polyodon, 19

Polyodontida, 19

powachia, Eltrop. 3

Pomatobrancbii pontica; Raja, 106

Poroderma, 28, 31 primus, Sturio, 13

Prionida, 19

Prionodon, 19

prionurus, Sq. 32

Pristidurus, 32

Pristinæ, 87

Pristiophorus, 87

Pristis, 88

Pristisida, 23, 87

Pristides, 87

Pristiurus, 32

Pristobatus, 87

Proceros, 19

Propterygia, 105

Psittacodon, 21

Pterocephalina, 127

Pteroceplata, 133

Pteroplatea, 122, 127

punctata, Raja, 106, 108 Torp. 101

punctatum, Chil. 35 punctatus. $\mathrm{Sq} .37,60$ punctulatus, Must. 57 purpurea, Tryg. 117 pusillum, Acanthid. 72 pygmæus, Ac. 7,12

\section{Q.}

yuadriloba, Rhinopt. 132 juadrimaculata, Raja, 109 guisqueaculeata, Raja, 130 Quoyii, Cestr, Gi;
R.

radiata, Raja, 107

radula, Taja, 105

Rafinesquî, Scaphir. 18

Raia, 81

Raiæ, 104

Rajdæ, 23, 81, 91, 104

Raii, 8$]$

Rajaæ, 81

Ruja, 104

reticulatus, Polyodon, 20

Ihina, 78, 92

Rhinæ, 91

Rhineodon, 66

Rhineodontis, 66

Rhinobates, 94

Rhinobatine, 91

Rhinobatis, 91

Rhinobatus, 93

Rhinodon, 66

Rhinoptera, 131

Rhodius, Elops, 9, 12

Rhyncobatus, 92

Rineodon, 62

Rondeletii, Carch. 61

$\begin{array}{ll}, & \text { Ichthyoc. } 17 \\ , & \text { Lamp. } 138 \\ , & \text { Phal. } 55\end{array}$

Fondoletii, Att. 13

rostellata, Raja, 108

rostrata, Raja, 94, 95

rostratus, Ac. 10,12

$$
\begin{array}{ll}
\text { "An. } 9 \\
\text { "Seyma. } 77 \\
\text { Sq. } 60
\end{array}
$$

ruber, Amm. 146

rubicundus, Ac. 16

rubus, Raja, 106

rupertianus, Ac. 9

Russellii, Sq. 4:

, Tryg. 116

ruthenicus, Ac. 7

Rutheuus, Ac. 7

ruthenus major, Ac. 9

s.

Sabina, Tryg. 119

Salvian, Sturio, 13

Salviani, Centr. 73

, Raja, lu9

Sanuuisuya, Petrom. 14]

sarophagus, Dal. 76

saxatilis, Can. 3i)

sayi, Tryg. 120

Scaphirb ynchus, 16

Schenlenii, Platyr. 98

schippa, Ac. 6

Schlegelii, Rhinop. 97

Schultzii, Raja, liz scbypa, ac. $6,11,16$

Scoliodon, 41

Seylliadæe, 23, 27

sicyllini, 27

Scyllium, 27

") Triakis, 55

Sicylliorhinus, 27,32

Scymous, 73

secundus, Sturio, 13

Selaca, 23

Selacha, 23

Selache, 61

Selachus, 61

Selaciens, 23

selanonus, Sq. 59

semisagittatus, Prist. 90

Sephen, Hypol. 123

Septoeil, Petrom. 115

serotinus, Ac. 16

Syrra, 89

Shavianus, Cetorh. 62

Shiudrake, Tenkee, 1*21

sinensis, Ac. 6

Platy r. 98

Smithii, Carch. 61

, Lept. 51

, Raja, 112

"Rhinopt. 132

Somniosus, 76

Sorra, Koma, 49

Sorrah, Sq. 47

Spallanzanii, Oxyr. 60 $\mathrm{Sq} \cdot 46$

spatula, Polyodon, 20

spatularia, 19,20

speculum, Raja, 108

Sphyrnias, 48

Sphyrua, 48

Sphyrnia, 48

Spiuaces, 69

Spinacini, 69

spinax, 71

spinicauda, Elip. 121

spinosa, Raia, 105

, Raja, 106

spinosus, Echinorh. 78

Squadon, 89

Squalj, 24

Squaliana, 40

Squalita, 23, 2।

Squalini, 52

Squalus, 24, 29, 41

squamosus, Centr. 71

Squatiua, 24, 29, 79

Sifuatinx, 78

Squatinidæa, 78

Squatinini, 78

Squatino-Raja, Rhinob. 94

squatinoraiæ, 8 ?

squatinoraia, 9]

squatoraja, 97 
Stampella, 19

Stegostoma, 38

stellure, Scyll. 30

stellaris, Aut. 11

$$
\text { , Must, } 56
$$

, Sq. 29,30

stellata, Raja, 107

stellatus, Ac. 7,?

Sterlatx, 6 Gal. 56

Sterlet, 7

Sterleta, 7

sterlet, Ac. 7

striatus, Sq. 31

strogylopterus, Tryg. 120

Sturionida, 4

Sturio, 4, 13

sturio, Ac. 7, 12, 13

Sturiona, 3, 4, 19

Sturiones, 9

Sturiouellus, Ac. 13

subcinerea, Lamp. 140

Sueruga, 10

Sympterygia, 113

Syorhina, 94

T.

Tæniura, 124

Tasmaniensis, Narc. 102

Taurus, Odont. 63

Temera, 103

Temminckii, Sy. 48 tentaculata, Etop. 127

tentaculatus, Sq. 88

terræ-novæ, Carch. 41

testacea, Trygonoph. 126

Thalassia, Tryg. 118

thalassinus, Gal. 55

Thalassorhinus, 55

Thouini, Rhinob. 95, 96

tibura, Sphyr. 50

tiburio, Cestror. 50

$\begin{array}{ll}" & \text { Sphyz.50 } \\ " & \text { Sq. } 50 \\ \text { Z } & \text { Zyg. } 50\end{array}$

Tiburon, 60

tigrinus, Galeoc. 51

$$
\begin{array}{ll}
" & \text { Scyll. } 39 \\
, & \text { Sq. } 38
\end{array}
$$

Timlei, Narc. 1 ${ }^{*}$

Tollo, 29

Torpedo, 99

Torpedine, 99

Torpedines, 91, 99

Torpedinina, 93

torpedinus, Tryg. 125

transmontanus, Ac. 9

Tremapnea, 22

Trematopnea, 22

Trematopnes, 22

Tremelga, 100

Triænodon, 51

Trienodontes, 51

Trianodontini, 5]

Triakiana, 39

Triak is, 55

trialendatus, Petrom. 144

Triglochini, 62

Triglocbis, 42,63

Trigones, 114

Trigonina, 114

Trigoninæ, 114

Trispeculare, Hemisc. 33

Truncatus, Dinectes, 18

Trygonobatus, $\mathbf{1 1 6}$

Trygonoptera, 126

Trygonorhina, 97

tuberculatum, Chil. 35

tuberculatus, $\mathrm{Sq} .35$

Tucka, Ac. 11

Tudes, Sphyr. 50

turutus, Ac. 6

typicus, Rh. 67

typus, Rhinob. 96

U.

Uarnak, Tryg.116

Ujo, Daryb. 121

unagi, Joatzma, 138

undulata, Raja, 105

undulatus, Rhinob. 96

unicolor, Amu. 146

unimaculata, Torp. 100 ; 101

Uraptera, 113

Urogymni, 1]4

Urogymnus, 114
Urolophi, 125

ustus, Sq. 46

uyatus, Acanth. 71

V.

vacea, $\mathrm{Sq} .68$

vampyrus, Cephal. 134

variegata, Torp. 100

variegatum, Scyll. 32

Velasia, 143

Telpecula, 21

vera, Centr. 21

verus, Carch. 61

violacea, Tryg. 119

virgata, Raja, 105

vittatus, Proc. 19

vomer, Raja, 110

vulgaris, Acanth. 70

, Cat. 29

, Galeus, 53

" Must. 56

, Sq. 61, 79

, Trsg. 119

Vulpecula, 72

Vulpes, 64

Thal. 55

"Alop. 64

Fultur, Myliob, 129

W.

Walga, Tryg. 117

Walshii, Torp. 100

Y.

Yarrellii, Carch. 48

Z.

Zebra, Hetera. 65

Zygæna, 48

Zugei, Tryg. 120 



\section{EXPLANATION OF THE PLATES.}

). 1, Fig. 1.-Mouth, showing the teeth of Petromyzon marinus. Fig. 2.

$"$

Fig. 3.

Fig. 4.

Fig. 5.

Fig. 6 .

"

,

,

9

,
Lampetra fluviatilis.

Geotria australis.

Velasia chilensis.

Caragola lapicida. Mordacia mordax, from Zool. Erebus and Terror, t. 38. 1. 2.-Geotria australis. 

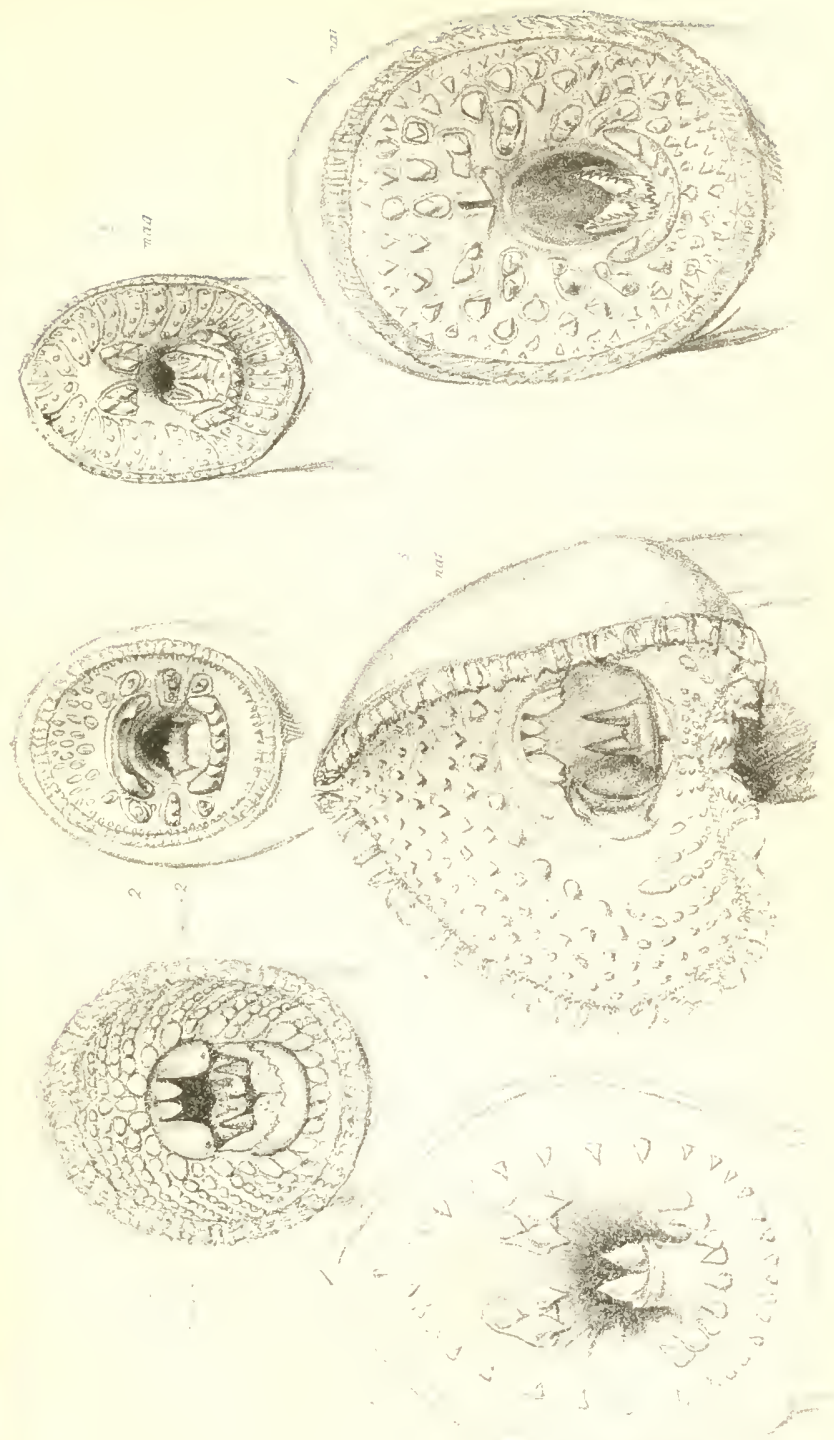









$$
\begin{aligned}
& \text { oitisli fusoum fot mol distory }
\end{aligned}
$$

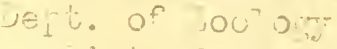$$
\text { uist, on the spe? in ans o? }
$$

isin

siow:

\author{
PLEASE DO NOT REMOVE \\ CARDS OR SLIPS FROM THIS POCKET
}

UNIVERSITY OF TORONTO LIBRARY 
